Winter 2006

\title{
Theocratic Constitutionalism: An Introduction to a New Global Legal Ordering
}

Larry Catá Backer

Coalition for Peace and Ethics

Follow this and additional works at: https://www.repository.law.indiana.edu/ijgls

Part of the Constitutional Law Commons, International Law Commons, and the Law and Politics

\section{Commons}

\section{Recommended Citation}

Backer, Larry Catá (2006) "Theocratic Constitutionalism: An Introduction to a New Global Legal Ordering," Indiana Journal of Global Legal Studies: Vol. 16 : Iss. 1 , Article 5.

Available at: https://www.repository.law.indiana.edu/ijgls/vol16/iss1/5

This Symposium is brought to you for free and open access by the Law School Journals at Digital Repository @ Maurer Law. It has been accepted for inclusion in Indiana Journal of Global Legal Studies by an authorized editor of Digital Repository @ Maurer Law. For more information, please contact rvaughan@indiana.edu.

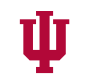

JEROME HALL LAW LIBRARY

INDIANA UNIVERSITY

Maurer School of Law
Blooming ton 


\title{
Theocratic Constitutionalism: An Introduction to a New Global Legal Ordering
}

\author{
LARRY CATÁ BACKer*
}

\begin{abstract}
The twentieth century has seen a fundamental shift in the ways in which constitutions are understood. By the middle of the twentieth century, a new sort of constitutionalism emerged, rejecting the idea of the legitimacy of every form of political self-constitution. The central assumptions of this new constitutionalism were grounded in the belief that not all constitutions were legitimate, and that legitimate constitutions shared a number of universal common characteristics. These common characteristics were both procedural (against arbitrary use of state power) and substantive (limiting the sorts of policy choices states could make in constituting its government and exercising governance power). These procedural and substantive norms were, in turn, an articulation of a "higher law" of the community of nations, reflecting a global communal consensus evidenced in common practice or international agreements. The authority and legitimacy of this global secular transnational constitutionalism has not gone unchallenged. On the one hand, state power traditionalists reject the notion of extra-national normative constraints on constitution making. On the other hand, there has been an intensification of challenges from universalists of different schools, from natural law theorists to pluralist constitutionalists. Among the most potent of these groups have been religious transnational constitutionalists who have argued that one or another of the current crop of universalist religions ought to serve as the foundation of normative disciplining of constitution making. But do these movements represent constitutionalism? If they do, then what are their characteristics?

This article examines these questions from the context of the most developed form of

* Director, Coalition for Peace and Ethics, Washington, D.C.; Professor of Law, Pennsylvania State University. Email: lcb911@gmail.com. My thanks to Miguel Schor and Adeno Addis, who have inspired and enriched my approach to this material. Special thanks to my research assistant, Augusto Molina, for excellent work on this project.
\end{abstract}

Indiana Journal of Global Legal Studies Vol. $16 \# 1$ (Winter 2009)

OIndiana University Maurer School of Law — Bloomington 
theocratic transnational constitutionalism - that of Islam. The object will be to examine the great variation of Islamic and Islamic-influenced constitutions to see if these represent the emergence of a constitutionalism with characteristics that can be clearly articulated, if it is possible within this system to distinguish between legitimate and illegitimate constitutions, and if there are characteristics of this constitutionalism that clearly distinguish it from secular transnational constitutionalism. Part I critically reviews the main currents of twenty-first century notions of constitutionalism and focuses on theocracy as a principle of governance. Part II suggests the possibility of fusing the legitimating structures of modern constitutionalism with the substantive framework of theocracy to produce a possible set of characteristics that would mark a legitimate Islamic constitutionalism, distinguishing Islamic constitutions from Islamic constitutionalism. Part III then applies this understanding of theocratic constitutionalism to the constitutional "families" of religious constitutions in which Islamic law has become part of the structural architecture of the constitution itself, suggesting points of convergence and divergence with the values and norms of secular transnational constitutionalism.

\section{INTRODUCTION}

The twentieth century saw a fundamental shift in the ways in which constitutions are understood. ${ }^{1}$ The century saw a movement away from a consensus, however tenuous, that constitutions were necessarily expressions of the internal social, political, and economic choices of a unique, territorially-bounded, political community. ${ }^{2}$ Constitutionalism, then, was internally directed and focused on legalityRechtsstaat notions. ${ }^{3}$ The critical questions of constitutionalism were the authenticity

1. Dernonstration of this shift was an object of my earlier article, Larry Catá Backer, God(s) Over Constitutions: International and Religious Transnational Constitutionalism in the 21st Century, 27 Miss. C. L. REv. 11 (2008).

2 See Westel W. Willoughby, The Fundamental Concepts of Public Law 30 (1924). Willoughby, like his contemporaries, rejected a natural law or universalist approach to constitutional settlement and instead embraced the notion that "the State may be conceived of as itself the sole source of legality, the fons et origo of all those laws which condition its own actions and determine the legal relations of those subject to its authority." Id.

3. As originally understood, it focused on the lawfulness of action-that is that a governmental action be taken strictly in accordance with law-but did not limit the range of lawful assertions of government power. "The Rechtsstaat could provide redress against administrative action but stopped short of providing a general sanction against governments. As a result, the Prussian government was strictly non-responsible in both a political and legal sense." GORDON SMTTH, DEMOCRACY IN WESTERN Germany 9 (1979). See id. at 186-88 for a discussion on traditional Rechtsstaat. For a discussion about its modern incarnation, see Nobushige Ukai, The Individual and the Rule of Law Under the New Japanese Constitution, 31 IND. L.J. 733, 735-737 (1956). See also THOMAs M. FRANCK, FAIRNESS IN 
of the polity, the formal legality of the power of the state apparatus to act, and the conformity of the actions of the state (legislature, executive, and courts) to the requirements of law (protection against arbitrary action). ${ }^{4}$ The results could be perverse, but as long as they conformed to the law, they might be considered legal. ${ }^{5}$ Those choices, however odious, were legitimate to the extent there was power to enforce them. The loci of authority, sovereignty, elections, citizenship, and formalist conformity to process (due process without substantive values) were the key variables. ${ }^{6}$ Verticality of authority was not a necessary prerequisite. The U.S. Constitution expressly insisted on its supremacy in writing and provided a difficult procedure for modification. ${ }^{7}$ This was not necessarily obvious to others; in later constitutions, the relationship between the law of the constitution and that of other acts was ambiguous, with a power in the legislature, for example, to amend either without much difficulty. Other states might express their agreement or disagreement with the internal constitutive choices of other states, and the local population might seek to change the choices or rebel, but the legitimacy of the constitution itself was a function principally of the legality of its content and the integrity of the system employed to enact and enforce it. Where the choices were sufficiently offensive to powerful foreign states in ways that conflicted with the interests of those more powerful states, offending states might be reduced to either secondary or colonial status. ${ }^{8}$ This con-

INTERNATIONAL LAW AND INSTITUTIONS 41 (1995) ("In most national communities, a law draws support from its having been made in accordance with the process established by the constitution, which is the ultimate rule of recognition.").

4. See Carl Schmitt, Legality and Legitimacy 18 (Jeffrey Seitzer ed. \& trans., 2004). For the softer American conventional version, see Constitutionalism: THE Philosophical Dimension 4 (Alan S. Rosenbaum ed., 1988).

5. For a discussion of the perversities of these systems in extreme cases-that of Nazi Germany and Vichy France, see Vivian Grosswald Curran, Fear of Formalism: Indications from the Fascist Period in France and Germany of Judicial Methodology's Impact on Substantive Law, 35 CORNELL INT'L L.J. 101 (2002).

6. A lively theoretics of constitutions was produced at the end of the nineteenth century to reflect these concerns. See, e.g., Albert V. Dicey, Introduction to the Study of the Law of the ConstiTUtion 3-35 (9th ed. 1952). But authoritarian constitutionalism also had its proponents. For an example from an early twentieth century analysis of the Japanese Imperial Constitution, see Hirobum I Ito, Commentaries on the Constitution of the Empire of Japan (Miyoji Ito trans., $2 \mathrm{~d}$ ed. 1906).

7. See, e.g., Edward S. Corwin, The "Higher Law" Background of American Constitutional Law (Cornell University Press 1974) (1928).

8. Relying on contemporary academic opinion, Willoughby, for example, understood that:

Just as, in municipal law, they are regarded as the possessors of independent wills and as the entities in which are vested certain rights and responsibilities, so, in international law, they are viewed as political persons having definite rights and obligations. This status they have, however, in full effect at least, only insofar as 
sensus changed. Led by American academic and political elites seeking to remake a world upended by a half-century long war ${ }^{10}$ in which most political and power relationships had been affected," by the middle of the twentieth century there emerged the notion, ${ }^{12}$ articulated first successfully in the German ${ }^{13}$ and Japanese ${ }^{14}$ post-war constitutions, that not all constitutions were legitimate..$^{15}$ Constitutionalism required more than the enactment of a written constitution, even one concerned with formal protection against arbitrary use of power (the use of power not other-

they are regarded as members of what is known as the "Family of Nations," which Family does not include all the States of the world but only those nations which have reached a certain degree of civilization.

Willoughby, supra note 2, at 307 (citing Pitt Cobbett, Leading Cases and Opinions on International Law 27 (3d ed. 1909)).

9. See Catá Backer, supra note 1, at 24-33; see also American Constitutionalism ABroad: Selected Essays in Comparative Constitutional History (George Athan Billias ed., 1990).

10. Some historians have begun to understand the First and Second World Wars as intimately interrelated. See, e.g. Rene Albrecht-Carrie, France, Europe and the Two World Wars 10 (1961) ("The two world wars and the intervening period thus constitute a single unit.").

11. For a sense of the consciousness of those changes, although from a source contemporary sensibilities will likely find objectionable, see Oswald Spengler, The Hour of Decision (Charles F. Atkinson trans., 1934).

12. William M. Wiecek, American Jurisprudence After the War: "Reason Called Law," 37 TuLSA L. Rev. 857, 861 (2002) (citing Seymour M. Lipset, The First New Nation: The United States in Historical and Comparative Perspective (1963); Friedrich A. von Hayek, The ConstituTION OF LIBERTY (1960)) ("Seeking to restore a moral component to political thought, political theorists were determined to adapt the old ideal of the rule of law to the conditions of the modern state. Eminent scholars, such as Friedrich von Hayek, Louis Hartz, and Seymour M. Lipset, extolled the virtues of constitutionalism, defining it as a commitment to the rule of law. That core characteristic of the liberal state included limited government, protection for individual rights, and a role for the judiciary under such protection.").

13. See Grudegesetz für die Budesrepublik Deutschland (Basic Law for the Federal Republic of Germany) (1949), available at http://www.bundestag.de/interakt/infomat/fremdsprachiges_ material/downloads/ggEn_download.pdf.

14. For the Japanese post-war constitution, see Nihonkoku Kenpō (Constitution of Japan) (1946), available at http://www.web.japan.org/factsheet/pdf/CONSTITU.pdf.

15. "[T] he legitimation effect can be defined as the process through which systematic losers come to understand themselves as part of the system, as self-governing, and as having willed their losses and their subordinate status." Orly Lobel, The Paradox Of Extralegal Activism: Critical Legal Consciousness and Transformative Politics, $120 \mathrm{HARv}$. L. REv. 937, 958 (2007). On the meaning of legitimation as a political and legal concept in the modern era for the validation of political and legal acts, see, e.g., Herbert L.A. Hart, The Concept of Law 100-10 (2d ed. 1994). For the intersection of legitimacy and constitutionalism in the area of environmental justice, see, e.g., Steven Bernstein, Legitimacy in Global Environmental Governance, I J. INT'L L. \& INT'L REL. 139 (2005). 
wise conferred by law). ${ }^{16}$ Legitimate constitutions shared a number of common characteristics. ${ }^{17}$ These common characteristics were both procedural (against arbitrary use of state power) and substantive (limiting the sorts of policy choices states could make in constituting its government and exercising governance power). ${ }^{18}$ These procedural and substantive norms were, in turn, an articulation of a "higher law" of the community of nations, reflecting a global communal consensus evidenced in common practice or international agreements. The notion of a higher law suggested a necessary universalism with roots in both natural and religious law. ${ }^{19}$ Constitutionalism in the twentieth century was tied to the construction of a collective-an international society of states ${ }^{20}$ - with the object of universalizing standards of behavior and of preserving the power relationships within and among states from threats." "The system thus brought into being was thus a product of the

16. See, for example, H.W.O. Okoth-Ogendo, Constitutions Without Constitutionalism: Reflections on an African Political Paradox, in CONSTITUTIONALISM AND DeMOCRACY 65 (Douglas Greenberg et al. eds., 1993), for a discussion of constitutionalism and how it becomes a tradition. Constitutionalism in this vein has been understood as the memorializations of a methodology for the protection of fundamental values. See, e.g., Keith E. Whittington, Yet Another Constitutional Crisis?, 43 WM. \& MaRY L. REv. 2093, 2139 (2002).

17. For a powerful example of this form of constitutionalism, see Carlos Santiago Nino, The Constitution of Deliberative Democracy (1996).

18. This substantive constitutionalism changed the nature and focus of process constitutionalism. In Germany, for example,

[t] he result of raising the Basic Law to a pre-eminent position by making the Rechtsstaat directly enforceable has not been simply to place the constitution above politics but in an important way to make it a determinant of politics.... That slant is evident in the view that the Basic Law imposes certain constitutional tasks (Verfassungsaufträge) which require fulfilment [sic], in a somewhat programmatic sense. These "tasks" are frequently held to be embedded in the clauses setting out individual rights....

SMITh, supra note 3, at 55 . Smith also states that " $t$ ]he period after 1945 can be said to have witnessed the 'emancipation' of the Rechtsstaat in Germany. Yet it is strange that an idea which for so long had been central to the German legal tradition should have been made subordinate to the dictates of arbitrary authority." Id. at 186.

19. Dale Patrick, Old Testament Law 7 (1985) ("By 'higher law' is meant what is truly just and right... The very capacity to argue over what the law should be depends upon an existence of a scheme of principles and values to which both parties in the argument make appeal. The universality of this law is demonstrated by the capacity to visit foreign countries and conform without unreasonable adjustment to the law of each ...").

20. See, for example, Martti Koskenniemi, The Gentle Civilizer of Nations (2001), for a discussion of the historical aspects of international law and society.

21. As R.J. Barry Jones put it, "The institutionalisation of the sovereignty of states, and the use of power balancing mechanisms, formed the basis of what some analysts have dubbed an interna- 
character, needs and interests of its constituent parts-the member states-or, rather, of the dominant interests within those states. . ."22 It was secular. ${ }^{23}$ Late twentieth century constitutionalism represented an attempt to systematize, institutionalize, and implement as international higher law, a long-held view in Western legal and political circles of the basis for establishing a hierarchy of states by reference to their civilization. ${ }^{24}$

The object was to both impose a deeper and substantive meaning of rule of law constitutionalism on states and to find a mechanism for developing those substantive principles of domestic constitutionalism that might express transnational universal principles of right and justice rather than merely those of majorities within a particular state. This, it was thought, would provide a meta-norm for limiting the power of states and avoiding arbitrary or immoral conduct by subjecting those notions to international development and oversight. Under this system all states participate in the construction of universal normative constitutional standards, but none control it entirely (though some have a greater authority in the process-a nod to power), and all are technically subject to its strictures as international law (or as a means of legitimating domestic governance against internal or external threats)..$^{25}$ This new means of international ordering reduces the need for the traditional means of enforcementmilitary intervention or occupation-by creating a legal system for the coercive policing of the behavior and international constitution of states through "constitutionalism" that serves both to preserve the form of state sovereignty and the normative values of

tional society: a 'society', albeit, of states (or their ruling groups) devoted to the interests and maintenance of those states (or ruling groups).” R.J. BARRY JONES, GLOBALISATION AND INTERDEPENDENCE in the International Political Economy 50 (1995); see also Antony Anghie, Imperialism, SOVEREIGNTY AND THE MAKING OF INTERNATIONAL LAW 245-72 (2004) (arguing that the colonial history of international law is concealed within its reproduction, including its reproduction as the new forms of global governance).

22. JONES, supra note 21 , at 50.

23. Charles Taylor, A Secular Age (2007).

24. "The idea that societies which do not possess certain economic systems and corresponding political institutions should be regarded as outlaws that must be appropriately disciplined and reformed is a very old one." ANGHIE, supra note 21, at 269 (citing, in part, EMER DE VATTEL, THE LAW of Nations: OR, Principles of Law of Nature, A PPLied to the Conduct and AfFairs of Nations AND SOVEREIGNs (Joseph Chitty ed., 6th ed. 1883) (1758)). "What Vattel describes is something akin to an economic 'rogue state', a state that must be exterminated." Id. at 270.

25. For an acknowledgement and application, see Stephen J. Schnably, Emerging International Law Constraints on Constitutional Structure and Revision: A Preliminary Appraisal, 62 U. MIAMI L. REv. 417, 479-88 (2008) ("In the end, some internationalization of structural constitutional issues may be both unavoidable and even desirable. The ultimate violation of a constitution is a military coup, and one might think twice about returning to the days when coups were considered purely internal matters."). 
dominant state powers. ${ }^{26}$ Battles over transnational constitutionalism sometimes focus on power-the power to control or participate in the supranational contests for the production of universalist constitutionalist norms. ${ }^{27}$

The authority and legitimacy of this global secular transnational constitutionalism has not gone unchallenged. At its core, these contests are over the nature and context of authority. ${ }^{28} \mathrm{On}$ the one hand, state power traditionalists reject the notion of extra-national normative constraints on constitution making. ${ }^{29}$ On the other hand, a number of groups have accepted the legitimacy of transnational constitutionalism as a disciplining force but have rejected the notion that such restraints can be the product of a secular global political consensus. ${ }^{30}$ Among the most potent of these groups have been religious transnational constitutionalists who have argued that one or another of the current crop of universalist religions ought to serve as the foundation of normative disciplining of constitution making. ${ }^{31}$

26. ANGHIE, supra note 21 , at 270 ("Now, however, such deviant states are to be identified by all the economic criteria formulated by the IFIs [international finance institutions]; states that are protectionist, inefficient and encumbered by bureaucracy and government regulation must be eliminated, as it were, through SAPs [structural adjustment programmes] that will bring about their transformation into proper international citizens.").

27. Within the context of the meaning of human dignity and applicable human rights, the battlefield includes not only the apparatus of the United Nations, but also the production of norms and common understanding of right and justice from the opinions of the various human rights courts. See, e.g., Nihal Jayawickrama, The Judicial Application of Human Rights Law 3-23 (2002); The Globalization of Human Rights (Jean-Marc Coicaud et al. eds., 2003). Thus, "in spite of the progress of multilateralism and internationalism before and during the 1990 s, the international system remains largely nationally rooted, with state actors in competition." Jean-Marc Coicaud, Conclusion: Human rights in discourse and practice, in The Globalization of Human Rights, supra, at 178, 186.

28. "The justice of law, justice as law is not justice. Laws are not just as laws. One obeys them not because they are just but because they have authority." Jacques Derrida, Force de Loi: Le "Fondement Mystique de l'Authorite" [The Force of Law: The "Mystical Foundation of Authority"], 11 CARDozo L. Rev. 920, 939 (1990).

29. Thus, for example, "the business of the constitution is to express the polity's most basic legal and political commitments." Jed Rubenfeld, The Two World Orders, WiLson Q., Autumn 2003, at 22, 27.

30. Derrida reminds us, quoting Pascal with a nod to Montaigne, of that ancient strain of fundamental understanding of law, justice, and the constitution of political society: "simple reason tells us that nothing is just in itself; everything crumbles with time. Custom is the sole basis for equity, for the simple reason that it is received; it is the mystical foundation of its authority. Whoever traces it to its source annihilates it." Derrida, supra note 28, at 939. But he then reminds us of the moral of that insight - that "the origin of authority, the foundation or ground, the position of law can't by definition rest on anything but themselves ...." Id. at 943 .

31. Consider an example from Chechnya.

As for the more radical islamist project, its supporters considered that the sole 
Religion finds its way into the constitutional framework of states in a variety of ways. States engage with religion, as a formal matter, in different manners. Some states conflate legal and religious systems together. Some states sponsor or establish a religion. Others incorporate religious law as the law of the state, much like the American states incorporated the English Common Law. But do these movements represent a contextual variant of conventional constitutionalism? Or theocracy $?^{32}$ Or do they represent a different and autonomous basis for the constitution of states grounded in principle? Is there now arising a theocratic constitutionalism in opposition to and competing with conventional constitutionalism for a place as one set, or the supreme set, of organizing principles for states? If such a constitutionalism exists, what are its characteristics?

This article begins an examination of these questions. The context will be the most developed form of theocratic transnational constitutionalism-Islamic transnational constitutionalism. ${ }^{33}$ This is not to say that others have not sought similar roles for different faith communities. ${ }^{34}$ The object will be to examine the great vari-
possible Chechen democracy was a constitutional theocracy, the only reasonable alternative to western and Russian "politically and ideologically prostituted" con- stitutionalism. This model envisaged the suppression of democratic institutions, for instance, the substitution of a secret ballot by an open nominal referendum.

Alexei Kudriavtsev, Democratic Values and Political Reality in Chechnya, 1991-1999, in Democr acy and Pluralism in Muslim Eurasia 359, 369 (Yaacov Ro'i ed., 2004).

32. See Lucas Swaine, The Liberal Conscience: Politics and Principle in a World of Relgious PluRalism 2-4 (2006) (suggesting the elements of theocracy). Looking back to Josephus and the defense of the constitution of the Jewish state of Israel at the time of its destruction by the Romans, Swaine explains "Theocracy '[places] all sovereignty and authority in the hands of God." Id. at 2 (quoting Josephus Flavius, Against A AION (100 A.D.)). Swaine defines theocracy as "a mode of governance prioritizing a religious conception of the good that is strict and comprehensive in its range of teachings." Id. at 6-7. But Swaine considers theocracy existing with dominant liberal polities. Id.

33. But also note "[w]hat Islamic constitutionalism entails remains contested among Muslims as well as among Western scholars who study the topic." Ann Elizabeth Mayer, Conundrums in Constitutionalism: Islamic Monarchies in an Era of Transition, 1 UCLA J. IsLamic \& NeAr E. L. 183, 183 (2002). Note also that that Islamic theocracy is not the only manifestation of this drive toward a new constitutionalism. Hindu and Buddhist universalists are also active. See, e.g., Sheetal Parikh, Enshrining a Secular Idol: A Judicial Response to the Violent Aftermath of Ayodhya, 37 CASE W. REs. J. INT'L L. 85 (2005) (describing Hindu theocratic nationalism); Roshan de Silva Wijeyeratne, Buddhism, the Asokan Persona, and the Galactic Polity: Rethinking Sri Lanka's Constitutional Present, Soc. Analysis, Spring 2007, at 156-78, (describing Buddhist nationalist constitutionalism); Larry Catá Backer, Theocratic Constitutionalism: Buddhist Constitutionalism in Sri Lanka, Law at the End of the Day, http://lcbackerblog.blogspot.com/2008/06/theocratic-constitutionalism-buddhist. html (June 1, 2008, 7:23 EST).

34. See, e.g., Larry Catá Backer, Nehru Inverted: Building a Model for Theocratic Constitutionalism in India, Law at the End of the Day, http://lcbackerblog.blogspot.com/2007/12/nehru-inverted 
ation of Islamic and Islamic-influenced constitutions to determine whether one can argue that these constitutions represent the emergence of a constitutionalism with characteristics that can be clearly articulated, that it is possible within this system to distinguish between legitimate and illegitimate constitutions, and that there are characteristics of this constitutionalism that clearly distinguish it from secular transnational constitutionalism. After this introduction, Part I critically reviews the main currents of twenty-first century notions of constitutionalism. For that purpose it advances an understanding of constitutionalism developed in earlier work: constitutionalism is a system of classification, the principal object of which is to define the characteristics of constitutions, which is used to determine the legitimacy of a constitutional system either as conceived or implemented, based on the fundamental postulate of rule of law and grounded on values derived from a source beyond the control of any individual..$^{35}$ It then focuses on the relationship of constitutionalism to theocracy as a principle of governance. Its object is to situate a classical understanding of theocracy within the discourse of constitutionalism.

Part II, ${ }^{36}$ in turn, develops and situates the theocratic variant of constitutionalism within conventional constitutionalist debates, looking primarily at its Islamic constitutionalist form. It rejects the idea that the use of religion as an ordering principle of state can be understood only as a somehow flawed or heretical constitutionalism. It posits that, at least within some polities, religion might be emerging as the basis for ordering of a state no less principled and complete than its conventional counterpart. ${ }^{37}$ But the difference does not so much make the rising system flawed as incompatible with conventional constitutionalism. It suggests competition among legitimating constitutionalist systems for acceptance as the basic ordering principle of states, much as free market and Marxist worldviews vied for supremacy through the 1980s. The article attempts to extract from this examination a set of characteristics of legitimate Islamic constitutionalism, distinguishing Islamic constitutions from Islamic constiturionalism.

-building-model-for.html (Dec. 23, 2007,21:32 EST); Catá Backer, supra note 33.

35. See Larry Catá Backer, From Constitution to Constitutionalism: A Framework for Analysis of Nationalist and Transnational Constitutionalism, 113 PENN ST. L. REv. (forthcoming 2009), available at http://papers.ssrn.com/sol3/Delivery.cfm/SSRN_ID1311397_code259226.pdf?abstractid =1272264 \&mirid=1

36. See infra Part II.

37. In this respect, I suggest the possibilities of the rise of an alternative framework for state organizations a long principled lines that contrasts with the suggestion of the difficulty of that project expressed by others. See Abdullahi A An-Naim, Sharia and Positive Legislation: Is an Islamic State Possible or Viable, in 5 Yearbook of Islamic and Middle Eastern Law 29, 37 (2000). 
Part III ${ }^{38}$ then applies this understanding of theocratic constitutionalism to the constitutional "families" of religious constitutions in which Islamic law has become part of the structural architecture of the constitution itself. The focus, again, is principally on Islam and Muslim majority states. However, there will be a nod to states comprised of majorities of other religious communities. For my purpose here, the article adopts a formalist and institutionalist approach to religion. ${ }^{39}$ The object is to interrogate the connection between fully developed and institutionalized communities - political and religious. For that purpose, religion will refer to those faith communities collectively constitured through an institutional framework. ${ }^{40}$ The article suggests the ways in which constitutionalist discourse can provide a means for distinguishing between principled theocratic constitutionalism, however alien to the constitutionalist framework of secular states, from unprincipled (and perhaps less legitimate) forms of constitutions that provide a formal role for religion within its ordering framework.

The implications are significant for advocates of this or that form of constitutionalism as a privileged framework for legitimating state organization, or where illegitimate, for organizing internal or external resistance to the government constituted thereunder. Constitutionalism is a commodity —an important one, serving as an operating system for the organization of life within its operational scope. Like other commodities, it has gone global. As a proxy for a network of organizing relationships, it provides service and value to its consumers that vary with its character-

38. See infra Part III.

39. There may well be significant differences between constitutions in theory and in practice. Constitutions can be a sham. See Molly Warner Lien, Red Star Trek: Seeking a Role for Constitutional Law in Soviet Disunion, 30 Stan. J. INr'L L. 41, 63-64 (1994) (stating with respect to late Tsarist constitutionalism that "[a]t most the period could be described as sham constitutionalism, because there was no obligation on the part of the executive to work with the legislature, and no mechanism for ensuring government adherence to 'constitutional' norms."). This has certainly been the case even where the constitution is neither a sham nor a nominal constitution. See, e.g., Nathan J. Brown, Islamic Constitutionalism in Theory and Practice, in Democracy, the Rule of Law, ANd IsLam 491, 496-97 (Eugene Cotran \& Adel Omar Sherif eds., 1999) (on the Egyptian Supreme Constitutional Court and its engagement with Egyptian constitutional commands). Still, a study of the formal exposition of constitutional arrangements can serve us well in distinguishing between constitutions and constitutionalism and among the varieties of constitutionalism developed.

40. For a discussion of this limitation and its importance in the construction of constitutional approaches to religion, see Larry Catá Backer, Religion as Object and the Grammar of Law, 81 MARQ. L. REv. 229, 237-42 (1998). "Consequently, I do not believe that one can divorce Religion from the context in which it has existed in the world. Religion is not merely a series of conduct codes and precepts. Religion is not merely a moral philosophy, nor a naked spirituality. It is a world view..." Id. at 249. This worldview has its own law and institutions for its perpetuation. 
istics. We are quickly moving into an age where constitutionalism must be marketed to consumers, who increasingly have a power of choice among alternatives. ${ }^{41}$ It will no longer be sufficient to suggest that a competitor system ought to be avoided because it is a flawed version of the competitor. Each system will now compete on the basis of what it offers individuals within organized communities. Dialogue will center on convergence, separation, translation, and subversion of competing systems as each vies for dominance in the world market. To some extent, this will represent a return to a medievalism in which accommodation may be required because no system is strong enough to overwhelm the others, and all compete for supremacy within the peoples of the community of nations. ${ }^{42}$

\section{Constitutionalism and Theocracy: A Framework for Analysis}

I have described the variety of ways in which institutional religion serves as a critical political actor within constitutional systems. ${ }^{43}$ But is this evidence of a place for religion (like other subnational communities-factions) within constitutions, or does it suggest the emergence of something new-a theocratic constitutionalism-or a religiously based tyranny?

In order to understand the character of theocracy and the means for determining whether such systems may be judged legitimate or illegitimate, in accordance with the general framework evolving for that purpose, it is useful to examine the conventional system of constitutional taxonomy (and the judgments it fosters). The inquiry embraces the irony in taxonomy - both classification and application of the normative structure on which classificatory choice is made. For the application of this insight to the important issue of democracy and judicial review as a component of constitutionalism, conventionally understood, Miguel Schor suggests,

[m]aps, after all, are used to conceptualize the world. Similarly, scholars believe that order can be brought to the profusion of laws that populate the world by classifying and organizing them into families. Taxonomies, it is thought, facilitate the task of transferring laws be-

41. Cf. Robert Cover, The Supreme Court, 1982 Term-Foreword: Nomos and Narrative, 97 HARv. L. Rev. 4, 35-40 (1983) (on the competition between constitutionalist models within the antebellum United States).

42. See Larry Catá Backer, On Israel's 60th Anniversary of Statehood: Views From the Empire and the Caliphate, Law at the End of the Day, http://lcbackerblog.blogspot.com/2008/05/on-israels -60th-anniversary-of.html (May 16, 2008, 16:38 EST).

43. See generally Catá Backer, supra note 1 . 
tween nations. The problem with taxonomic approaches to comparative law, however, is that they obscure the tension between representing reality and orienting the user that maps ineluctably present. ${ }^{44}$

The basis of that taxonomy is the system of judgment we now understand as constitutionalism. Constitutions memorialize organization of state power. ${ }^{45}$ Constitutionalism serves as the metric by which such organization can be judged, legitimated, and modified. This judgment, when made by a substantially strong segment of the community of nations, now serves as a basis for political action against and within non-conforming states-justifying a variety of political action from sanctions and embargoes ${ }^{46}$ to military intervention, ${ }^{47}$

44. Miguel Schor, Mapping Comparative Judicial Review, 7 WASH. U. Global STUD. L. Rev. 257, 257-58 (2008).

45. Power might be usefully understood in Weberian terms, and as such, tied to notions of domination. See Max Weber, Basic ConcePts in Sociology 117 (H.P. Secher trans., 4th ed. 1966) (indicating that "[b]y power is meant that opportunity existing within a social relationship which permits one to carry out one's own will even against resistance and regardless of the basis on which this opportunity rests. By domination is meant the opportunity to have a command of a given specified content obeyed. ..”). Alternatively, a more amorphous and governance oriented approach to power is also useful. See e.g., Michel Foucault, Discipline and Punish: The Birth of the Prison (Alan Sheridan trans., Vintage Books 2d ed. 1995) (1975); Larry Catá Backer, Global Panopticism: States, Corporations, and the Governance Effects of Monitoring Regimes, 15 IND. J. GLOBAL LeGAL STUD. 101 (2008).

46. The classic modern example is the isolation of the constitutionally sanctioned apartheid government of South Africa. Referencing the South African experience, Steven Wheatley notes,

[a]s Michael Matheson has observed, there may be circumstances where the Security Council is justified in requiring a change in some aspect of the political structure of a state, where it determines that "doing so is necessary to restore and maintain international peace and security." The question is whether the right of peoples to political self-determination should be overridden by the "public interest in the maintenance of international peace and security," the pursuit of which is considered more compelling in the particular circumstances of the case.

Steven Wheatley, The Security Council, Democratic Legitimacy and Regime Change in Iraq, 17 EuR. J. INT'L L. 531, 543 (2006) (citing Michael Matheson, United Nations Governance of Postconflict Societies, 95 Am. J. INT'L L. 76, 85 (2001)); see also S.C. Res. 554, II 1, U.N. Doc. S/RES/554 (Aug. 17,1984 ) (where the Security Council declared the "new constitution" of Apartheid South Africa to be "contrary to the principles of the Charter of the United Nations.").

47. See Philipp Dann \& Zaid Al-Ali, The Internationalized Pouvoir Constituant: Constitutionmaking Under External Influence in Iraq, Sudan and East Timor, in 10 MAX PLANCK YEARBOOK OF United Nations Law 423 (Armin von Bogdandy et al. eds., 2006); Andrew Arato, Post-Sovereign Constitution-making and its Pathology in Iraq, 51 N.Y.L. ScH. L. REv. 535 (2006). 
revolution ${ }^{48}$ and civil war. ${ }^{49}$ Legitimation of this sort is sometimes understood in the American literature in economic terms appropriate to contracts. ${ }^{50}$

For all of its bluster in the literature, constitutionalism is quite protean in form. Like a piece of high quality spandex, it can be stretched over the body seeking to clothe itself in it. "At one end are views of constitutionalism that see the role of the constitution as delineating a national identity.... At the other end are views of constitutionalism that see the role of the constitution as imposing constraints, in the name of universalist conceptions of humanity ...."

The elasticity of constitutionalism is easy enough to describe. ${ }^{52}$ Many discus-

48. Iran provides a modern example.

Iran's clerics had been deeply divided about the legitimacy of the first Iranian constitution, which was promulgated in 1906. In order to conciliate the 'ulama, article 2 provided that no laws would be enacted that violated Islamic principles, and article 2 of the 1907 Supplement to the Fundamental Law provided that a tribunal of clerics would review proposed legislation to ensure that it did not conflict with the sharia. However, under the Pahlavi Shahs, the clerics discovered to their chagrin that they would not in practice have any way of blocking laws from being enacted where they deemed them in violation of the sharia.

Ann Elizabeth Mayer, Islam and the State, 12 CARDozo L. REv. 1015, 1038 (1991).

49. The classic modern example is East Timor.

The explicit entry of global institutions, such as the U.N. in East Timor and other such places, into constitution making is simply a more explicit form of the global nature of all local constitution making. It could not be done if there were no principles of global constitutionalism. If the local population insisted on a theocracy there would be no way to engage the U.N.

Karol Edward So Tan, Constitution Making at the Edges of the Constitutional Order, 49 WM. \& MARY L. REv. 1409, 1419 (2008).

50. Zachary Elkins et al., Baghdad, Tokyo, Kabul. . .: Constitution Making in Occupied States, 49 WM. \& Mary L. Rev. 1139, 1143-44 (2008) ("Unlike ordinary contracts, however, constitutional agreements have no external guarantor to enforce the terms, independent of the parties. To endure, constitutions must be self-enforcing, meaning they must give rise to an equilibrium from which no party has an incentive to deviate. Even though constitutions may produce relative winners and relative losers, they will endure to the extent that the losers believe they are better off within the constitutional bargain than in taking a chance on negotiating a new one.").

51. Robin West, Human Capabilities and Human Authorities: A Comment on Martha Nussbaum's Women And Human Development, 15 ST. ThOmas L. Rev. 757, 771 (2003) ("[E]ither pole of this axis, as well as any number of mid-way points along it, are plausible enough accounts of the way the idea of constitutionalism has been bandied about in theory and used in practice, at least in the United States.").

52. For a focused review, see generally Catá Backer, supra note 35. Much of the discussion of constitutionalism and its elasticity is drawn from that work. 
sions of constitutionalism seek to situate their discussion somewhere along this continuum and in the service of a particular purpose. All constitutionalism is justificatory-justifying a particular perspective or objective in the normative construction of the rules for understanding the character of systems of governance. It is deployed to justify the current reality-an apologist approach to constitutionalism. Alternatively, it is used as a repository of constitutional principles extracted from a reading of the "innards" of one or more constitutions out of which principles of constitution making might be extracted and then applied to all constitutions. ${ }^{53}$

For some, constitutionalism can be most usefully approached from the narrowing confines of the field of international law. They might suggest, for example, "as the defining feature of international constitutionalism-both erga omnes norms and jus cogens presuppose and refer to a sphere of common matters of mankind which have a higher normative rank than rules regulating interstate relations." ${ }^{54}$ The object of constitutionalism is thus tied to a project of supranational elaboration. That elaboration of constitutionalist theory is focused on the creation of an institutional supranational apparatus for the construction and enforcement of a set of universal principles of constitution making, ${ }^{55}$ or in the elaboration of a supranational system of customary constitutional law principles. ${ }^{56}$ The idea is sometimes reduced to a complex networking society of judges and courts on a global scale who relate to each other the way common law judges used to

53. This sort of structuralist/textualist approach to constitutionalism has a strong parallel to some methods of constitutional interpretation. See WILLIAM N. ESKRIDGE, JR. ET AL., LEgISLATION AND STATUTORY INTER PRETATION 249-75 (2d ed. 2006).

54. Ulrich K. Preuß, Equality of States_Its Meaning in a Constitutionalized Global Order, 9 CHI. J. INT'L L. 17, 39 (2008) ("Obviously the former rules include the principles laid down in the UN Charter, such as prohibition of the use of force (except the case of self-defense), respect for the political independence and territorial integrity of any state, and, most importantly, the protection of human rights as laid down in several international compacts.").

55. This is a subset of a movement that seeks in globalization of governance institutions a solution to the problems posed by the current state system. "For universalists, true universalization of international law requires the harnessing of participants, constituencies, stakeholders, sources, and influences into modern international legal processes." Gabriella Blum, Bilateralism, Multilateralism, and the Architecture of International Law, 49 HARV. INT'L L.J. 323, 324 (2008).

56. This would both mimic and supplement the construction of customary international law as "law." See, e.g., Andrew T. Guzman \& Timothy L. Meyer, Customary International Law in the 21st Century, in Progress in International LaW 197 (Russell A. Miller \& Rebecca M. Bratspies eds., 2008). The domestic dimensions of the domestication of customary international law have been a favorite of American law discourse for the last quarter century. See, e.g., T. Alexander Aleinikoff, International Law, Sovereignty, and American Constitutionalism: Reflections on the Customary International Law Debate, 98 AM. J. INT'L L. 91, 101-08 (2004); Beth Stephens, The Law of Our Land: Customary International Law as Federal Law After Erie, 66 FORDHAM L. REv. 393 (1997). 
function in the seventeenth and eighteenth centuries in England. 57 "In this context the internationalization effectively represents a blending and generalization of the consensus positions of appropriate or basic norms drawn from the evolving constitutional traditions of the member states of the supranational system." ${ }^{58}$

Constitutionalism is sometimes tied to both cosmopolitanism and to convergence theories. It can be tied to pluralism within a looser framework of shared ideals. It can sometimes be advanced as a reflection of "the abiding hope that from the shared culture, history, and ethos of these consanguineous states, [where] a homogeneous legal order can emerge." 59 In its natural law formulation, it suggests

certain principles of right and justice which are entitled to prevail of their own intrinsic excellence, altogether regardless of the attitude of those who wield the physical resources of the community.... In relation to such principles, human laws are, when entitled to obedience save as to matters indifferent, merely a record or transcript, and their enactment an act not of will or power but one of discovery and declaration. ${ }^{60}$

In any of these guises, the focus is on consensus on values within a framework through which such consensus can be legitimately formulated. Thus, constitutionalism suggests both institution building and a values system around which such institutions operate and for whose advancement they exist.

But the principal project of convergence-oriented, supranational constitutionalism is the search for consensus on values. It is, after all, hard to construct a system for evaluating the higher law of states without a framework of values against which constitutions can be assessed. It is in this project that one runs across both a great convergence of values and a resistance to such convergence. Consensus values "require[] imposing limits on the powers of government, adherence to the

57. See, e.g., Anne-Marie Slaughter, A New World Order (2004); Vicki C. Jackson, Constitutional Comparisons: Convergence, Resistance, Engagement, 119 HARv. L. Rev. 109 (2005); David S. Law, Generic Constitutional Law, 89 MinN. L. Rev. 652 (2005).

58. Catá Backer, supra note 35, at 112.

59. Margaret A. Burnham, Indigenous Constitutionalism and the Death Penalty: The Case of the Commonwealth Caribbean, 3 INT'L J. Const. L. 582, 614 (2005) (on the institution of the Caribbean Court of Justice).

60. CoRWIN, supra note 7, at 4-5 (emphasis omitted). For a classic critical discussion, see Roscoe Pound, The Ideal Element in American Judicial Decision, 45 HARv. L. Rev. 136, 148 (1931) ("Today we should be employing philosophical method in jurisprudence to set off and criticize the ideal element in systems of developed law ...."). 
rule of law, and the protection of fundamental rights." ${ }^{16}$ Or, as understood outside the United States, the values that inform constitutionalism, at its core, include

the ideas of "popular sovereignty" and a social contract as the source of the government; the principles of republicanism, federalism, separation of powers, and government limited by law; respect for the rights and liberties of citizens and the protection of private property; the rule of law and the supremacy of the Constitution; and independence of the judiciary and judicial review. ${ }^{62}$

Sometimes the shorthand for these values/judgment frameworks is "rule of law" understood either as process rights (limitations of individual discretion in assertions of government power) ${ }^{63}$ or substantive values (limitations on the sorts of assertions of power a government might undertake).

First, rule of law is understood as embedded in mandatory systems for maintaining firm limits on the arbitrary use of state power by the individual. This is the idea of rule of law in its process aspect, limiting the use of state power only when grounded in legitimately enacted law. Second, rule of law is understood in its substantive aspect as vesting the state with the critical role as guardian of a set of foundational communally embraced substantive norms that are to be protected and furthered through the use of state power grounded in law. ${ }^{64}$

But rule of law is also conflated with certain governmental systems, perhaps because they might serve as proxies for the values which are meant to serve as the

61. Michel Rosenfeld, Modern Constitutionalism as Interplay Between Identity and Diversity, in Constitutionalism, Identity, Difference, and Legitimacy: Theoretical Perspectives 3 (Michel Rosenfeld ed., 1994).

62. Vasiliy A. Vlasihin, Political Rights and Freedoms in the Context of American Constitutionalism: A View of a Concerned Soviet Scholar, 84 Nw. U. L. Rev. 257, 258 (1989).

63. "Today, the most common form of legitimacy is the belief in legality, i.e., the compliance with enactments which are formally correct and which have been imposed by an accustomed procedure." WEBER, supra note 45 , at 82.

64. Larry Catá Backer, The Rule of Law, The Chinese Communist Party, and Ideological Campaigns: Sange Daibiao (the "Three Represents"), Socialist Rule of Law, and Modern Chinese Constituiionalism, 16 Transnat'l L. \& Contemp. Probs. 29, 39 (2006); see also Randall Perrenboom, China's Long March Toward Rule of LaW 126-88 (2002). 
foundations of judgment. Among the most important are notions of democracy, ${ }^{65}$ citizenship, ${ }^{66}$ and human rights. ${ }^{67}$ There is a self-referencing quality to these notions. Thus, one starts from the notion that the "fundamental value that constitutionalism protects is human dignity." ${ }^{168}$ Human dignity is then bound up with forms of governance. It is common to note that in "the context of the human rights revolution, the main focus of the moral redefinition of the new democracies in contrast to the totalitarian regimes they replace is the latter's violation of human rights. ${ }^{\prime 9}$ This insight bends constitutionalist values discourse back to democratic principles. "In contrast to the presumed moral worth of nativism against the colonial rulers, the task in the era of new constitutionalism is the moral definition of democratic political community." ${ }^{\circ 0}$ Others approach constitutionalism as grounded in an implicit ordering of substantive constitutional values in which democracy and self-determination are privileged and other notions of substantive norms-particularly that cluster of behavior norms limiting the power of states against individuals—are subordinated.1

But all these values require both an authoritative source and a mechanism for elaboration, institutionalization, and enforcement. It is to those functions that

65. See, e.g., Boris Dewiel, Democracy: A History of Ideas (2000); Samuel Issacha roff, Constitutonalizing Democracy in Fractured Societies, 82 TEx. L. REv. 1861, 1861 (2004) (addressing "the role of constitutionalism in stabilizing democratic governance in ... fractured societies . . because of the limitations it imposes on democratic choice.").

66. See, e.g., Rian Barry, Culture and Equality: An Egalitarian Critique of Multiculturalism (2002); Seyla Benhabib, The Rights of Others: Aliens, Residents, and Citizens (The SeEley Lectures) (2004) (on citizenship and moral personhood).

67. "The fundamental value that constitutionalism protects is human dignity." Walter F. Murphy, An Ordering of Constitutional Values, 53 S. CAL. L. REv. 703, 758 (1980). "In the context of the human rights revolution, the main focus of the moral redefinition of the new democracies in contrast to the totalitarian regimes they replace is the latter's violation of human rights." James T. Richardson, Religion, Constitutional Courts, and Democracy in Former Communist Countries, ANNALs Am. ACAD. PoL. \& Soc. Scl., Jan. 2006, at 129, 135-36. The human rights focus is also tied to democratic principles. "In contrast to the presumed moral worth of nativism against the colonial rulers, the task in the era of new constitutionalism is the moral definition of democratic political community." Id. at 135.

68. Murphy, supra note 67 , at 758 .

69. Richardson, supra note 67 , at $135-36$.

70. Id. at 135.

71. See e.g., Noah Feldman, Imposed Constitutionalism, 37 Conn. L. Rev. 857 (2005). For a critical discussion, see Catá Backer, supra note 35. This is, of course, hardly new to Feldman. See, e.g., Welshman Ncube, Constitutionalism and Human Rights: Challenges of Democracy, in THE INSTITUTIONALISATION OF Human Rights in SOUTHERn Africa 1 (Pearson Nherere \& Marina d'Engelbronner-Kolff eds., 1993) ("Representative government is at the heart of democracy and constitutionalism. Without it is idle to speak of the constitutional protection of human rights."). Id. at 14. 
constitutionalism also devotes itself. It is in the search for sources of authority and legitimacy, as well as for the institutional framework within which these values may be embraced legitimately, that much of constitutionalism is devoted. It is here that the great schism between nationalist and international (or transnational) constitutionalism is most apparent. ${ }^{72}$ This schism is of particular interest to American constitutionalists. ${ }^{73}$

For Americans, the question of constitutionalism, especially in its form of judicial interpretive power, reduces itself to three questions, all relating to power. The first focuses on the legitimacy of interpretive methods. The object is to avoid judicial despotism by forcing judicial discourse to privilege forms of analysis that reduce the ability of judges to substitute their personal predilections for that of the community reflected in the constitution... The second targets the use of foreign sources-now understood in its larger context as a battle over control of the essence of the character of the state and its relationship to other states and the community of nations. The other targets the constitutional power of the legislature, the popular in popular constitutionalism. ${ }^{74}$

On the one hand, traditionalists continue to adhere to the view that constitutions are creatures of their context. "Although law is by no means static, legal evolution in each country is distinct and will produce vastly different outcomes. Far from converging over time, legal institutions remain different." 75 On the other hand, internationalists and universalists suggest that though context is to be respected, universal principles are to be privileged. ${ }^{76}$ Much constitutionalist discourse, though, sits some-

72. See Catá Backer, supra note 35.

73. See id.

74. Id. at 142 .

75. Katharina Pistor et al., The Role Of Law And Legal Institutions In Asian EcoNOMic DEVELOPMENT 1960-1995, at 35 (1999) (noting that "law and legal evolution are part of the idiosyncratic historical development of a country, and that they are determined by multiple factors, including culture, geography, climate, and religion.").

76. The key lies in the post-1945 efforts at globalizing constitutions.

The focus of this constitutionalism was transnational and secular. It was grounded on the rules of behavior derived from the understandings and sensibilities of the community of states. In this sense it was self-referencing and meta sovereign-the system essentially moved ultimate discretion up from any individual state to the community of states. 
where in the middle. Examples of this include Asian or Asian values ${ }^{77}$ constitutionalist discourse. But some discourse is constitutionalist only in a post facto sort of way. ${ }^{78}$

Despite this great elasticity, it is possible to sketch out the contours of constitutionalism as a framework for judging constitutional legitimacy. ${ }^{79}$ Constitutionalism is, in its broadest conception, a Weltanschauung, a system of beliefs relating to power in the world, and specifically to that power that is asserted to organize and run a political organization, and its expression through law. ${ }^{80}$ Constitutionalism invokes both evocative symbolism as well as instrumentalism-an ordered system or systematization of belief.

Catá Backer, supra note 1, at 37-38.

77. Thus, for example, "The Bangkok Declaration was the high tide of the 'Asian values' argument, at least at the formal policy level. Whatever the niceties of its phrasing, the instrument was widely understood as based on the argument that Asians shared distinct values that were incompatible with values shared by Westerners and that therefore the West should not rely on its construction of human rights to intervene in affairs of Asian states." Tim Lindsey, Indonesia: Devaluing Asian Values, Rewriting Rule of Law, in Theories and IMPLEMENTATION OF RULE of LaW IN TWELVE Asian COUNTRIES, FRANCE AND THE U.S. 286 (Randall Peerenboom ed., 2004); see also Tu Weiming, Implications of the Rise of "Confucian" East Asia, DaEDalus, Winter 2000, at 195 ("The Confucian insistence on the importance of equality rather than freedom, sympathy rather than rationality, civility rather than law, duty rather than rights, and human-relatedness rather than individualism may appear to be diametrically opposed to the value-orientation of the Enlightenment. It is unsurprising that the "Asian values" advocated by political leaders such as Lee Kwang Yew and Mahatir often provoke strong cynical reactions in the West."); Jeffrey Usman, Non-Justiciable Directive Principles: $A$ Constitutional Design Defect, 15 Mich. ST. J. INT'L L 643 (2007) (on the Indian Constitution).

78. Or better put, constitutionalism tends to provide substantial evidence to support Nietzsche's old observation about the miscausation of politics and political theory. See generally Larry Catá Backer, The Führer Principle of International Law: Individual Responsibility and Collective Punishment, 21 PenN St. INT'L L. Rev. 509 (2003). Thus, I have suggested elsewhere that:

Much that passes for constitutionalism and constitutionalist discourse are veiled attempts to justify particular political settlements—and to justify them usually within a targeted group of states. Alternatively, constitutionalism serves as a mask over state building efforts at an international level, either as part of efforts to overthrow the secular state system or to federalize that system by the creation of a global federal state. In any case, the object is to move the locus of authoritative pronouncements over legitimacy of state organization-and its relationship with the people within a state-from individual political states to supra-national or international organizations. Constitutionalist discourse, then, tends to serve as post facto justification for political or legal conclusions that require legitimization.

Catá Backer, supra note 35, at 148.

79. See Catá Backer, supra note 35, at 148.

80. "Constitutions, like all creations of the human mind and the human will, have an existence in men's imagination and men's emotions quite apart from their actual use in ordering men's affairs." Max Lerner, Constitution and Court as Symbols, 46 YALE L.J. 1290, 1293-94 (1937). 
As an ordering system, constitutionalism focuses on classification. Constitutionalism provides a taxonomy of state organization, serving to distinguish those clusters of contextualized features that are consonant with the ideological ends of constitutionalism from those others which must be deemed illegitimate. "Constitutionalism is a political ideology that consists of various principles and assumptions about the dual nature of the individual as private person and public citizen, the nature of the state, and the nature of the complex set of relationships between the individual and the state." ${ }^{\prime 1}$

Taxonomy leads to an underlying normative structure that has crystallized along now familiar Rechtsstaat and Sozialstaat lines. It is at this level of constitutionalism that most of the academic, political, and ideological debate occurs. That debate has two principal parts. First, what principles are to be included in the ideological construct, and second, from where are these principles to be derived. The parts are interrelated. Constitutionalism's easy answers to its substantive component garner consensus when stated at a very broad level of generality: protection of the higher law status of the constitution in both black letter and by an appropriate mechanism (an independent judiciary or constitutional court system), rule of law, democracy, consent, limited government, interdiction of arbitrary acts, actions taken in accordance with law, and respect for human rights and dignity as such notions are commonly understood by the community of nations. But beneath this consensus-based listing lies substantial discord.

Constitutionalism is thus most dynamic at the level of implementation. Traditional nationalist constitutionalism looks inward for its ideology as well as its yardstick for measuring others. Transnational constitutionalism looks to the common constitutional traditions of the community of states buttressed by international norms and organizations. "It concedes the possibility that the desires of a majority of its population may be checked by an ideology in the development of which it may participate but which it does not control." ${ }^{\prime 2}$

Transnational constitutionalism suggests that a global system of constitutional values regulation is not only possible but also legitimate. Adherents of this constitutionalist perspective accept the customs, traditions, and understandings of the community of nations as the only legitimate source of ultimate authority for the elaboration of substantive constitutional values. "All states have a stake in the con-

81. Edward A. Harris, Living With the Enemy: Terrorism and the Limits of Constitutionalism, 92 Colum. L. Rev. 984, 986 (1992) (reviewing John E. Finn, Constitutions In Crisis: Political ViolenCe AND THE Rule of Law (1991)).

82. Catá Backer, supra note 35, at 154. 
struction of constitutionalist values, but none control its development. Like states in a federal system, all are bound by the higher law of global constitutional values which serve as a limit on contextualist variation." ${ }^{83}$ Within this universally applicable set of values, privileged above other values, the extent of mandatory harmonization is defined as well as the scope of permissible contextual variation. Beyond the boundaries of those values, the local, expressed as institutionalized government power, is legitimately subject to attack. Constitutionalism in its transnational form, then, provides a substantive values framework that is transcendent, at least in the sense that no state can singularly control its content. It can be understood as a bottom-up transcendence-universal values are the product of consensus from the practice of those who would be bound. Domestic courts would be expected to internalize the consensus values of the constitutional traditions of the community of nations, with margins of appreciation where consensus has not yet developed. ${ }^{84}$ It does not derive principally from values received from above. International constitutionalism proceeds from a similar position but also embraces the notion of the need to construct supranational institutions to serve as the authoritative sources of constitutional law values to be inscribed in all domestic constitutions.

But might other values frameworks also comport with constitutionalism? Is constitutionalism inseparable from the specific values that are currently privileged among states and in the academic discourse? The answer, one would suspect, is yes. Thus, from worldview to implementation, constitutionalism has systematized thinking about constitutions. It serves as a powerful framework for theorizing and evaluating constitutions and, perhaps most important, as the metric for evaluating the scope and depth of necessary constitutional modification within any polity. The basics of constitutionalism are now stable and universally embraced. They are grounded in the need to distinguish government from despotism, tyranny from communal selfconstitution. All constitutionalism, if it means to be understood as such, elaborates

(1) a system of classification, (2) the core object of which is to define the characteristics of constitutions (those documents organizing political power within an institutional apparatus), (3) to be used to determine the legitimacy of the constitutional system as conceived or as implemented, (4) based on rule of law as the fundamental

83. Id. at 155 .

84. See Larry Catá Backer, Inscribing Judicial Preferences into Our Fundamental Law: On the European Principle of Margins of Appreciation as Constitutional Jurisprudence in the U.S., 7 TULSA J. COMP. \& INT'L L. 327 (2000) (discussing margins of appreciation in the context of supranational values limits on constitutional authority). 
postulate of government (that government be established and operated in a way that limits the ability of individuals to use government power for personal welfare maximizing ends), and (5) grounded on a metric of substantive values derived from a source beyond the control of any individual. ${ }^{85}$

But each of those characteristics is understood and applied through a prism of fundamental ordering substantive values. ${ }^{86}$

Constitutionalism is thus exquisitely values-based, but it is in the search for those values that modern political communities-modern constitutionalist political communities in particular-clash most fiercely. The current competition between national and transnational constitutionalism for primacy is evidence of that possibility. Can the substantive values frameworks of universalist religion, for example, serve as a basis for transnational constitutionalism to legitimate constitutional forms inconsistent with the values represented by secular transnational constitutionalism? Would its proponents even stop to ask?

The simple answer ought to be that governments grounded on religion, even on religion written into a constitution, would be hard-pressed to pass for legitimate constitutional systems. That certainly has been the consensus on the relationship between theocracy and constitutionalism. Theocracy has been associated with despotism. In the absence of a controlling authority from outside the religious community, religion tends to subordinate those communities of unbelievers over which it might assert political authority. In an earlier work, I explained the role of religion within emerging secular transnational constitutionalism: "Religion divides and does not compromise. It tolerates but cannot accept equality among those of different faiths.... Within the hierarchy of norms, the religious was treated as subordinate to universal secular and political norms." ${ }^{87}$ This hierarchy makes sense in a system in which customary norms developed among a heterogeneous community of nations. Among all the values identified as foundational to transnational constitutionalism, the primacy of religion or religious values is not among them. But what if the hierarchy of values was inverted? What if the foundational organizing norm of a constitutional system was religion, or specifically a religion? Would a constitutionalist system still be possible?

Over a century ago, Europeans were skeptical of such an inversion. There was

85. Catá Backer, supra note 35, at 108.

86. Id.; see also Catá Backer, supra note 1, at 16-37.

87. Catá Backer, supra note 1 , at 37. 
a sense of theocracy tied to old regime despotism in Europe. ${ }^{88}$ That notion carried over to Islamic governance from the nineteenth century. Jacob Burkhardt suggested an inverse relationship between religion and constitutionalism, focusing on the state of Islam in his time and from his perspective in Central Europe. ${ }^{89}$ "And now we must again turn to Islam, with its stranglehold on national feeling and its miserable constitutional and legal system grafted onto religion, beyond which its peoples never advanced." 90 But others have noted the possibilities of an ordering of a legal state grounded in religious legal institutions. ${ }^{91}$ The issue was the conflation of faith and state, "for Islamic law was an integral part of the Islamic faith, and a threat to it could be seen as a step toward forced conversion." ${ }^{92}$ Thus, legitimacy could be tied as effectively to fidelity to faith as it might be tied to fidelity to other sources of communal norms in the constitution of a legal order. In the United States, certain Protestants viewed these ideas as both tied to what they called the old (and now superseded) Hebrew theocracy and its usurpation by the "Romish theory of the Church." ${ }^{93}$ Inherent in the idea was that theocracy, the resort to divine revelation as

88. See Nora E. Hudson, Ultra-Royalism and the French Restoration 17 (1936) ("[T]he theocrats looked back to ancient times when divine power played a large part in government.").

89. JaCOB BurcKhardt, Force and Freedom: Reflections on History (James Hastings Nichols ed., Meridian Books 1955) (1943).

90. Id. at 178. ("The state, as a political picture, is here supremely uninteresting; in the Caliphate practically from the outset, a despotism without responsibility or heaven or earth was taken for granted, and even, by a highly illogical twist, by its renegades."). Burckhardt was no less hard on Christian theocracy. Referring to the Counter-Reformation Catholic institutions, he noted that the "Church, it is true loved no State, yet inclined toward that system which was most willing and able to carry out persecutions for it. It adjusted itself to the modern state as it had once adjusted itself to the feudal system." Id. at 162. For more on the conflation of theocracy and despotism, see GEORG W. F. Hegel, The Philosophy of History 171-76 (John Sibree trans., P.F. Collier 1902) (1837).

91. Speaking of the colonization of Muslim majority territories, it was noted that "a colonial regime could not threaten to eliminate [Islamic law] or tamper with it without running grave risks ...." allan Christelow, Muslim Law Courts and the French Colonial State in Algeria 6 (1985).

92. Id.

93. Charles Hodge, 3 Systematic Theology 543 (Wm. B. Eerdmans Publ. Co. 1981) (1871).

So soon as faith becomes nothing other than submission to an external authority, theology is necessarily reduced to be the mere redaction of a code of canon law. Is a discussion raised in the Church, the contesting powers soon cease to argue, and seek to evoke a decision of the Roman court, which shall crush the adversary and put an end to the dispute. Religious truth is then not a matter of knowledge or of reason, but of politics and diplomacy.... In the Roman system it becomes thenceforth impossible to find the slightest basis for a constitutional opposition to the sovereignty of the Pope.

Auguste Sabatier, The Religions of Authority and the Religion of the Spirit 11 (1904). 
a source of law and the resort to priests as the source of governance, was transitory. ${ }^{94}$ This was the central idea exported from out of the West to other parts of the world. Thus, for example, Sun Yat-Sen understood this transitory notion of theocratic governance and the religious framework for law, in a Chinese context. ${ }^{95}$

There have been a number of contemporary attempts to define theocracy, drawing from a variety of old and new sources. But these too suggest a fundamental inconsistency between theocracy, as system, and constitutionalism. Lucas Swaine, for example, draws on Josephus for his definition. ${ }^{96}$ Swaine defines theocracy as "a mode of governance prioritizing a religious conception of the good that is strict and comprehensive in its range of teachings." ${ }^{97}$ For others, "[t]he word is often used to connote government by a specific institutional faith-Shia imams in Iran, say, or Wahhabi clerics in Afghanistan -with the clergy writing laws and a temple guard enforcing them." ${ }^{98}$ But not just with respect to Islam. Christian theocracy, in something like a modern form, existed, if only briefly, in Europe. ${ }^{99} \mathrm{Be}-$

94. Thus, for example, Max Weber, in describing the validity of legitimate authority, identified the "sacredness of tradition" as the "oldest and most universally held legitimacy of authority." WEBER, supra note 45, at 81 . "Today, the most common form of legitimacy is the belief in legality, i.e., the compliance with enactments which are formally correct and which have been imposed by an accustomed procedure." Id. at 82.

95. He suggested that the

[t]hings unknown to our ancestors were regarded as divine. They believed in the divine right and power of the gods. Since men could not fight against nature with physical force, the geniuses instituted religion, and taught the people to pray for the coming of good things and the avoidance of calamities. Then the ancient tribes made their chief the head priest, and so the state and religion became identical. This is still true of Mongolia and Tibet where the Living Buddha is the political as well as the religious head of these territories. Indeed, our ancients said that the great affairs of the state were conquest and prayer.

Sun Yat-Sen, His Political and Social Ideals 267 (Leonard Shihlien Hsü compiler, 1933).

96. SWAINE, supra note 32, at 4-7 (identifying four components of theocracy based on religious understanding and recognition of the sovereignty of God:"(1) it is a strict way of governing; (2) a religious understanding of the good in theocracy; (3) religious authorities direct daily affairs in a community; and (4) all sovereignty is in God.").

97. Id. at 7 .

98. Ross Douthat, Theocracy, Theocracy, Theocracy, First THINGs, Aug.-Sep. 2006, at 23, 24 (book review).

99. For a discussion, see, e.g., Thomas 1. Cook, History of Political Philosophy from Plato to BURKE 327-37 (1936) "[S] tate and church were, through Calvin, united in one body, and government became, in essence, theocracy, or, perhaps more accurately, bibliocracy, the direct rule of God in the state through His ministers on earth, with the Bible as the sole source of law." Id. at 333. 
fore the collapse of Marxist universalism, it was common to understand Marxist constitutionalism in religious terms.

Theocracy is the accepted term for absolute government conducted by priests in the name of their deity, where the structures of state and church merge into one and the recipients of revelation and inspiration are in absolute control of every phase of life-in totalitarian control. The difference between a Christian theocracy and the atheist theocracy of Marxism lies, of course, in the kind of revelation received. ${ }^{100}$

But theocracy is inherently a nexus concept-it serves at the meeting point of a number of other governance notions. Kenneth Cragg suggested the complexity a generation ago. ${ }^{101}$

In the bare literal sense of the word, there never has been and never can be a theocracy in human affairs. For God is a Spirit, eternal and Divine. He does not sit immediately in any national senate or upon any political throne to rule. His reign is necessarily involved in the viceregency of man. Islam has always recognized this truth. God is in heaven; government proceeds on earth. Theocracy, then, in any feasible sense, must mean Divine authority in and through human institutions. ${ }^{102}$

These ideas are not unique to Islam. ${ }^{103}$

100. Eduard Heimann, Reason and Faith in Modern Society: Liberalism, Marxism, and Democracy 153 (Wesleyan University Press 1961) (1955).

101. See Kenneth Cragg, The Call of the Minaret (1956).

102. Id. at 161 .

103. See, e.g., Benedict de Spinoza, A Theologico-Political Treatise and a Political TreaTISE 62 (R.H.M. Elwes trans., Dover Publ. 1951) (1670). Spinoza was well known for having made this connection in considering whether it was rationally possible to posit God as a "law giver or potentate ordaining laws for men." He uses the biblical story of God's command to Adam to avoid eating the fruit of the tree of knowledge, arguing that if that had been a divine command, it would have been impossible for Adam to disobey.

But since Scripture nevertheless narrates that God did give this command to Adam, and yet that nonetheless Adam ate of the tree, we must perforce say that God revealed to Adam the evil which would surely follow if he should eat of the tree, but did not disclose that such evil would necessarily come to pass. Thus it was that Adam took the revelation to be not an eternal and necessary truth, but a law.... From the same cause, namely from the lack of knowledge, the Deca- 
Theocracy points to the source of substantive principles and rules. But a divine source of rules does not necessarily suggest the form of its implementation among the community of believers and those under their control. For that purpose, there must be a connection between divine will and divine command in a form reducible to law. There must also be an institutional mechanism for implementing that divine will in legal form. But they suggest no connection to constitutionalism. A government of priests is not understood as a government of laws whose powers are restricted and defined, and whose construction respects rule of law norms.

The conventional understanding of theocracy, then, is a gateway to the more difficult question of implementation. It is here that theocracy fractures, but it does so within its own internal logic. Questions of theocracy, for example, produce discussion of theonomy or divine nomocracy--"government administered in accordance with a divine system of law." ${ }^{104}$ Theocracy, on the other hand, may suggest a direct rule of the Divine through unalterable and inflexible commands. "In a classic theocracy, God is the ruler, and the means through which he rules-priests, judges, prophets etc.- - have very minimal flexibility. In a religious nomocracy the divine law does indeed exist, but the power is invested in the hands of its interpreters." ${ }^{05}$ That dialogue, rather than the modern one between secular constitutionalism and religion as a governing force, has endured in modern Islamic debates about the nature of government. Ann Elizabeth Mayer correctly suggested the contours almost twenty years ago.

At the risk of overgeneralization, one could assert that in premodern Islamic political thought, where the system envisaged was a di-

\footnotetext{
logue in relation to the Hebrews was a law, for since they knew not the existence of God as an eternal truth, they must have taken that as a law that which was revealed to them in the Decalogue... But if God had spoken to them without intervention of any bodily means, immediately they would have perceived it not as a law, but as an eternal truth.
}

Id. at 63; see also Allan Arkush, Moses Mendelssohn and the Enlightenment 143-45 (1994) (discussing the philosophical synthesis between and the progressive principles of the enlightenment).

104. Brenda Oppermann, The Impact of Legal Pluralism on Women's Status: An Examination of Marriage Laws in Egypt, South Africa, and the United States, 17 HASTINGS WOMEN's L.J. 65, 67 (2006).

105. Gideon Sapir, Religion and State in Israel: The Case for Reevaluation and Constitutional Entrenchment, 22 HaST. INT'L \& COMP. L. REv. 617, 640 n.83 (1999). Sapir further notes that "[a]s Aaron Kirschenbaum has observed, 'The distinction between theocracy and religious nomocracy is not merely semantic; its ramifications are far reaching. . . Any Jurist knows that the law is not the ruler but rather the interpreter." Id. (citing Aaron Kirschenbaum, Teokratya Yehudit Jewish Theocracy], 8 DineI ISRAEL 223, 225 (1977)). 
vine nomocracy, there was no concept of a legitimate secular political authority, that Islamic law was the only law recognized as such, and that there was a highly developed system of pluralism, wherein a tolerated but subordinate status was allotted to non-Muslims. The premodern tradition remains influential, and one still sees ambivalence in Muslim milieus on questions such as whether constitutionalism and popular sovereignty are compatible with Islam, whether it is permissible to accord equality to non-Muslim citizens, and what the role of religious law should be in national legal systems. ${ }^{106}$

There is an appeal in theonomy, especially among evangelical Christians in the United States. ${ }^{107}$

Neither theocracy nor divine nomocracy comprehends the discourse of constitutionalism. It recognizes a value system that is directly applied by that community responsible for its elaboration. "If there is one inalienable feature of the Muslim body politic and legal culture it is the prevalence of the rule of law, with the political sovereign accepting without challenge the supreme authority of the divine law and hence that of the jurists and judges-custodians of the law and its interpreters as well as the civic leaders of the Muslim communities wherever they were present." 108 Nomocracy speaks the language of law, and even of rule of law, perhaps, but not the language of constitutionalism. ${ }^{109}$

106. Mayer, supra note 48, at 1016.

107. For a germinal work in the field, see Rousas J. Rushdoony, THe Institutes of Biblical LAW (1973).

108. Wael B. Hallaq, "Muslim Rage" and Islamic Law, 54 Hastings L.J. 1705, 1708 (2003). As Wael Halliq noted,

The idea of giving to Caesar what is Caesar's and to God what is God's does not wash in the Muslim world-view, for Caesar is only a man, and men, being equal, cannot command obedience to each other. Obedience therefore must be to a supreme entity, one that is eternal, omnipotent, and omniscient. If modernity has effected profound changes in Islamic culture (and no doubt it has), it has failed in the most important respect, namely, to alter or sever this tie with the divine.

Id. at 1706.

109. See generally, Larry Catá Backer, Retaining Judicial Authority: A Preliminary Inquiry on the Dominion of Judges, 12 W. \& MARY BiLl RTs. J. 117, 174 (2003) (demonstrating the common mistake of conflating the rule of law with constitutionalism-especially when considering legal rather than divine or religious nomocracy.).

Legal nomocracy, like its religious counterpart, can enhance democratic value, providing a meritocratic basis of sorts for the operation of the state. In that sense, 


\section{Toward a Theocratic Constitutionalism}

In a sense, then, theocracy, narrowly understood, points to a subset of the inquiry demanded within a constitutionalism framework. Implementation of a certain form does not necessarily follow from the acceptance of the supremacy of a divinely-mandated system of behavioral norms. This appears to be the case even within Islam - at least as understood by others.

All the current debate on actualizing the Islamic ideology in the Islamic society revolves around these questions. What is clear to most who attempt to answer can be stated in this way. Islamic polity must be based on Islam. The ideals of the Qur'ân and the Prophet are sufficient to it. The business of the Islamic state is to serve these Islamic concepts. Islam demands the entire allegiance of the believer and the state should insure as best it may that those demands are satisfied. Beyond that, there is division. ${ }^{110}$

More recently, some have criticized the convention of dismissing theocracy as an anachronism. ${ }^{11}$ Others have begun to see in the religious organization of constitutional states the possibilities of a constitutionalism normatively different from others and legitimately constitutionalist on its own terms. One of the more powerful arguments recently advanced is that of Ran Hirschl. ${ }^{112}$ It is worth considering

nomocracy both twists and enhances the fundamental organizing principles of our Republic. In an ironic twist of causation, I suggest that the priest did not usurp dominion over the herd. Instead, the herd, for its own preservation, demanded the overlordship of the priest.

Id.

110. CRAGG, supra note 101 , at 162.

Some would have the organs of state as free as possible, developing a creative obedience to Islam with an over-all court, somewhat like the Supreme Court in the United States, to determine whether particular legislation was inconsistent with the Shariah. Others would tie the state very firmly, in both constitution and life, to the traditionally interpreted Sharìah in the hands of the "Ulamā"

Id.

111. See SwAINE, supra note 32, at 3-4 (describing theocracy as outdated and without "relevance to democratic life").

112. Ran Hirschl, The Theocratic Challenge to Constitution Drafting in Post-Conflict States, 49 WM. \& MArY L. Rev. 1179 (2008); see also Jason Lawrence Reimer, Comment, Finding Their Own 
in detail, both for its approach to the religious element in constitutionalism and for highlighting the weaknesses of that approach, in light of what I have described as the framework for constitutionalist analysis. Hirschl, in a sense, serves as a proxy for the deficiencies of current analyses of religion within constitutionalism. I then sketch the constitutionalist contours of states, the substantive normative basis of which is grounded in religion. ${ }^{113}$ These reflect different perspectives from which the identity and complexities of a legitimating theocratic constitutionalism might be usefully extracted.

Hirschl seeks to explore "key aspects of constitutionalism in a theocratic world." 114 He approaches the issue of theocratic constitutionalism not on its own terms, ${ }^{115}$ but from a specific normative position — constitutional theocracy poses a threat to the established transnational constitutionalist order and must be dealt with accordingly. It must either be tamed so that it becomes nothing more than a more colorful variant of transnational constitutionalism, or it must be reworked and secularized. ${ }^{16}$ Identifying "challenges posed by the theocratic surge to canonical power-sharing, consociational models for mitigating tensions in multiethnic polities," He then proffers "constitutional responses to the problem of 'religion and state' and examines a few innovative legal developments employed by countries in the Islamic world to hedge the challenge of constitutional theocracy." 119 For the project of secularization, as a counter to the theocratic drive, he offers examples from "Egypt, Pakistan, Turkey, Israel, Nigeria, Malaysia, and other polities facing deep social and political tensions along the secular/religious divide." 20

For Hirschl, constitutional theocracy is a challenge, one that requires co-opt-

Voice? The Afghanistan Constitution: Influencing the Creation of a Theocratic Democracy, 25 PenN St. INT'L L. Rev. 343 (2006).

113. See Catá Backer, supra note 1.

114. Hirschl, supra note 112 , at 1181 .

115. For a discussion of approaching constitutionalism on its own terms, see Catá Backer, supra note 64 , at 38-52. "While grounded in neutral language, these arguments are, in reality, applied expressions of a particular ideology that has assumed universal acceptance outside of China in the period after the end of the Second World War." Id. at 50.

116. See Hirschl, supra note 112, at 1181 . He also notes that "principles of divine authority and theocratic governance are often at odds with international human rights regimes and principles, perhaps most tellingly in the contexts of religious freedoms, gender equality, or reproductive liberty." Id. at 1185.

117. Id. at 1181 .

118. Id. at 1188-91.

119. Id. at 1181 .

120. Id. 
ing and mitigation. That is, the challenges of such constitutionalism are those very characteristics that distinguish it from classical post-war Western constitutionalism. ${ }^{121}$ The point is to subordinate these differences within the matrix of superior normative values represented within transnational constitutionalism, so that the populations of states that seek to politicize their religion will do so only in a manner that retains the superiority of secular values. ${ }^{122}$ Yet, because the differences are normative rather than procedural, it is harder to write around or constrain the substantive differences represented by the legal implications of religious supremacy within a political order. Thus, Hirschl explains, "the theocratic challenge is inherently more difficult to overcome through constitution drafting than, say, divisions along ethnic or linguistic lines. This undermines the applicability of traditional power-sharing, 'consociational' constitutional models commonly proposed as a way of mitigating tensions in troubled multi-ethnic polities." ${ }^{.23}$

The problem of theocratic constitutionalism is of a different order than the more well-worn problems of ethnic, linguistic, or national divisions. Hirschl notes four principal differences. The first "more than any other divisions along ascriptive or imagined lines, the secular/religious divide cuts across nations otherwise unified by their members' joint ethnic, religious, linguistic, and historical origins." 24 This might have led Hirschl to the determination that religions are not so much a problem as a different and complete form of substantive constitutionalism. ${ }^{125}$ Instead,

121. Id. at 1181-82. Thus, Hirschl is clear in pointing to his baseline for analysis.

The literature on constitutional design and engineering is voluminous. Its ca-
nonical tenor suggests that when constitutionalization is seen as a pragmatic
"second order" measure-as opposed to instances of constitutionalization in-
volving a more principled, first order "we the people" outlook-it may help insti-
tutionalize attempts to mitigate tensions in ethnically divided polities through
the adoption of federalism, secured representation, and other trust-building and
power-sharing mechanisms.

Id.

122. Id. at 1182 ("[A]lthough there are many examples of discussions of the mitigating potential of constitutional power-sharing mechanisms to ease rifts along national, ethnic, or linguistic lines, scholars of comparative constitutional design have given little attention to the increasing divisions along secular/religious lines.").

123. The challenge presented by this tension is highlighted by an examination of the constitutional failures of Palestine and "[c]onflict settings where internal strife is high and state capacity is low merely exacerbate these difficulties." Id. at 1186 (citing Donald L. Horowitz, Conciliatory Institutions and Constitutional Processes in Post-Conflict States, 49 WM. \& MARY L. Rev. 1213 (2008)).

124. Id. at 1182.

125. See Catá Backer, supra note 1, at 57 ("In a universalist theocratic transnational constitutionalist context, the people must also look to their constitutional traditions informed by the precepts of 
Hirschl perhaps overly diminishes the normative importance of religion as an institution (as well as a belief and communal system) by suggesting that religion is "closer in nature to less visible categories such as income deciles, social class, or cultural milieu than it is to other kinds of markers such as race, gender, or ethnicity." ${ }^{26}$ It is not clear that is the only way to perceive religion within even a variegated polity. The example suggests not so much the similarity of religion to class, as the way in which social class might serve as a proxy for an intensity of religious adherence. It does not suggest the character of the normative basis of religion as a constitutional foundation-it merely suggests the demographics of its acceptability within a political community that varies by class and educational level, but in which a single religion can claim a majority of adherents.

The second difference springs from the first. Because not every member of a religious community believes the same way and with the same intensity, religion cannot serve as a unifying framework consistent with constitutionalist notions. This is particularly acute where the population is well-marbled. Thus, he argues, the "territorial boundaries of the secular/religious divide are often blurred. Although residents of certain regions within a given country may be more prone to holding theocratic views than residents of other regions, this divide is not neatly demarcated along territorial lines, as is often the case with ethnic or linguistic boundaries." 127 For Hirschl, the differences in religious sensibilities, even among members of the same faith community marks a crucial challenge to traditional constitutionalism. But it is a challenge with an odd consequence-for Hirschl implies that where religious intensity might be territorially marked, separation might be a possible solution. This suggests both that religion might well serve as a substantive basis for constitutionalist organization (a point he developed later) and that segregation is a legitimate device of traditional constitutionalist ordering. ${ }^{128} \mathrm{He}$ offers Sri Lanka as a

religion, which they might affect but only as members of the religious community and to the extent permitted under the rules of that community.").

126. E.g. Hirschl, supra note 112, at 1182. "[M]ost cosmopolitan and traditionalist Egyptians define themselves as members of the same nation, speak the same language or dialects of it, treasure the Pharaoh dynasty, and share the same ancestral ties. Importantly, however, some Egyptians are close adherents of religious directives, while others follow them more casually." Id. (citing U.S. Dep't of State, Annual Report on International Religious Freedom 2001 (2001) 421-29, available at http:// www.state.gov/documents/organization/9001.pdf).

127. Hirschl, supra note 112, at 1182-83.

128. Id. at 1183 ("Territory-based power-sharing mechanisms-or any other kind of joint governance structures that are based on the allocation of powers or goods by a regional key-may not be an efficient means for analyzing, let alone reducing, tensions along secular/religious lines."). 
contrasting example, where religious differences are territorially more marked. ${ }^{129}$ Yet this might be an odd conclusion for a theoretics based on the subordination of religion as a privileged source of substantive constitutional norms.

The third basis for distinction of religion as a constitutionalist problem is based on perception. Hirschl faults the West for portraying "the spread of religious fundamentalism in the developing world as a near-monolithic, ever-accelerating, and allencompassing phenomenon." 130 Rejecting the idea that religion, as a basis for constitutional settlement, is a threat to the substantive values of traditional secular transnational constitutionalism, ${ }^{131}$ he argues that "the picture in most predominantly religious polities-Islamic, Jewish, Roman Catholic, or Hinduist-is much more complex and nuanced, reflecting deep divisions and strife along secular/religious lines, as well as widely divergent beliefs, interpretations, and degrees of practice within religious communities." 132 As such, there is an implicit presumption that religion presents itself like other social variables whose internal differences and contradictions can be exploited by a superior and overarching system of values. ${ }^{133}$ Of course, that might suggest as a counter to fractious religion some sort of superior and monolithic alternative-the substantive norm systems of secular transnational constitutionalism. ${ }^{134}$ The very existence of a normative constitutionalist alternative suggests that the differences might be both horizontal (insurmountable inconsistencies) and vertical (subordination to a greater political universalism).

And that brings Hirschl to the most important distinction between religion

129. Id. But see Catá Backer, supra note 33.

130. Hirschl, supra note 112 , at 1183.

131. Hirschl cites Talal Asad, Genealogies of Religion: Discipline and Reasons of Power IN Christianity and IsLam 27-29 (1993) (in a chapter on religion as an anthropological category) for this proposition. See also Hirschl, supra note 112, at 1183. Yet, ironically, Hirschl seems to embrace a consequence of Asad's observation, one that Asad criticizes, that religion has an autonomous essence, "not to be confused with the essence of science, or of politics, or of common sense-- [that] invites us to define religion (like any essence) as a transhistorical and transcultural phenomenon." ASAD, supra, at 28. Asad tellingly notes that "[i]t may be a happy accident that this effort of defining religion converges with the liberal demand in our time that it be kept separate from politics, law and science-spaces in which varieties of power and reason articulate our distinctively modern life." Id. To a degree, Hirschl's perspective is one consonant with "a strategy (for secular liberals) of the confinement and (for liberal Christians) of the defense of religion." Id.

132. Hirschl, supra note 112, at 1184.

133. Id. ("In virtually all of these countries, the very nature of the sociopolitical order has been highly contested; civic ideology, an often relatively cosmopolitan lifestyle, and diverse policy preferences a re all often striving to establish or maintain their hegemony vis-á-vis embedded symbols of tradition, religiosity, and exceptionalism.").

134. For a discussion of how theocracy may threaten economic interests, see Leslie C. Griffin, Fundamentalism from the Perspective of Liberal Tolerance, 24 CARDozo L. Rev. 1631, 1633-35 (2003). 
and other divisional challenges for a legitimate constitutional order-the "uneasy union of constitutionalism and theocratic governance." 135 Yet where the recognition of this distinction might have led him, as it did me, to the recognition of religion as an alternative form of legitimate constitutionalist expression-legitimate in the way in which constitutionalism is manifested-this distinction leads Hirschl to a determination that religion, to the extent it might provide a basis in substantive constitutionalism, is heretical, and thus illegitimate. ${ }^{136} \mathrm{Hirschl}$, of course, is right - the fundamentals of religious substantive constitutionalism and the secular transnational constitutionalism of the developed world are incompatible. ${ }^{137}$ But he views the problem that results as pragmatic and directed to a particular end-he asks: "How can a polity therefore reconcile the principles of accountability, separation of powers, and the notion of 'we the people' as the ultimate source of sovereignty when the fundamental notion of divine authority and holy texts make up the supreme governing norm of the state?" 138

To view religion as a constitutionalist basis as heretical requires a recognition of the possibility of religious constitutionalism. Hirschl recognizes that "[a]t the uneasy intersection of two present-day trends-the tremendous increase of popular support for principles of theocratic governance and the global spread of constitutionalism - a new legal order has emerged: constitutional theocracy." ${ }^{39}$ Looking to the Egyptian constitution, Hirschl acknowledges the similarities between global constitutionalism and constitutional theocracy in the ways in which both embrace process constitutionalism. ${ }^{140}$ But critically, for Hirschl, these constitu-

135. Hirschl, supra note 112, at 1184.

136. Hirschl speaks of constitutional theocracy as something that defies or is unlike the normative constitutional structure of the United States and European states. See, e.g., id. at 1189 (discussing the Franco-American doctrine of strict separation between church and state). Hirschl also emphasizes the problematic aspect of religion and its challenge to the established constitutionalist order. Id. at 1186 (demonstrating Palestine's difficulty of establishing constitutional democracy within Islamic religious teachings). Difference, here, is a challenge that must be dealt with. But the character of the challenge is internal rather than external-because of the apparent assumption that religion cannot legitimately serve as a foundation of constitutionalist political orders.

137. See Catá Backer, supra note 1, at 61 ("Within the constitutional framework, religion is no longer an object with which a political community must deal. Instead, religion serves as the foundation on which political communities are constituted.").

138. Hirschl, supra note 112, at 1185 ("All of these countries face the sources of friction inherent in a constitutional theocracy-a potentially explosive combination by its very nature, and one that poses new challenges to conventional constitutional ideas about secularism, religious freedom, and the relationship between religion and the state.").

139. Id. at 1188 .

140. Id.; see Catá Backer, supra note 1, at 38-42 (comparing the Iranian constitution with others). 
tional theocracies do not embrace substantive or normative values that can legitimate them within the framework of existing global constitutionalism.

[C]onstitutional theocracies defy the Franco-American doctrine of strict structural and substantive separation of religion and state. Akin to models of "establishment" or "state religion," constitutional theocracies both formally endorse and actively support a single religion or faith denomination. Moreover, that state religion is enshrined as the principal source that informs all legislation and methods of judicial interpretation. ${ }^{141}$

Hirschl is right, but he misses the point. What he calls constitutional theocracy is not a defective global constitutionalism but a legitimating constitutionalism in its own right. By privileging the substantive values component of constitutionalism, ${ }^{142}$ he misses the point that the system, though inconsistent with his preferred values-based constitutionalism may present another form of valuesbased constitutionalism, which is constitutionalist, yet one whose substantive values are incompatible with that of secular transnational constitutionalism.

Still, Hirschl provides a useful starting point for defining constitutional theocracy. His definition emphasizes the theocracy part, as a means of distinguishing it from his normative constitutionalist baseline. His constitutional theocracy adheres to the form of constitutional organization but privileges one religion within the state apparatus, designating it as the supreme source of law, presided over by a formal system of interpretation in which the institutional apparatus of the privileged religion is vested with official or unofficial jurisdiction over interpretation of governmental activity in light of religious proscriptions. ${ }^{143}$

Despite recognizing the possibility of operating a theocracy in constitutional form, Hirschl still applies a traditional secular constitutionalist framework to judge the legitimacy and contours of such efforts. For Hirschl, the study of const-

141. Hirschl, supra note 112 , at 1189 .

142. See Catá Backer, supra note 35, at 8 .

143. Hirschl, supra note 112 , at 1190 (positing an ideal model of constitutional theocracy consisting of four elements: 1) "[A]dherence to some or all core elements of modern constitutionalism;" 2) The designation of a state religion; 3) "[T] he constitutional enshrining of the religion, its texts, directives, and interpretations as a or the main source of legislation and judicial interpretation of law-essentially, laws may not infringe upon injunctions of the state-endorsed religion;" and 4) A sharing of interpretative function among the state and religious authorities constituted therefore, so that the religious bodies "are also granted official jurisdictional status and operate in lieu of, or in an uneasy tandem with, a civil court system."). 
tutional theocracy has an objective-the quest for methodologies of ameliorating its effects in the service of a more traditional system of political subordination of religious normative governance frameworks. To that end, he describes "constitutional-institutional models for delineating the relationship between religion and state; these models are of crucial importance for our analysis of the phenomenon of constitutional theocracy." 144 It has another objective-the privileging of the "cultural propensities and policy preferences of secular, cosmopolitan, moderate elites in these countries"145 (now to be expressed in constitutionalist terms). For that purpose, Hirschl also offers another instrument-the constitutional court. ${ }^{146}$ He does not hide this objective, explaining, for example, that "constitutional courts may also be viewed as the guardians of secularism, modernism, and universalism against the increasing popularity of theocratic principles." ${ }^{47}$ Like Feldman, Hirschl puts a great deal of faith in constitutional courts to undo the theocratic elements, even those written into the black letter of constitutions. ${ }^{148}$

As a consequence, for Hirschl, constitutional theocracy cannot overcome a sense of illegitimacy. The fact that it is inconsistent with fundamental substantive norms of the international political order substantially undermines its legitimacy; that it is a fully-developed system makes it dangerous; that it is dangerous makes it something to be dealt with and overcome. ${ }^{149}$ While religious sensibilities must be respected, they cannot contradict or overcome the basic normative values of global

144. Id. at 1191. "In summary, even in the least likely settings, constitutional framers have been able to hedge or mitigate the tension between modern day needs and principles of theocratic governance through innovative constitutional design and reconstruction." Id. at 1199.

145. Id. at 1200-03.

146. Id. at 1200-09.

147. Id. at 1200 .

148. Id. at 1200-03; see also Noah Feldman \& Roman Martinez, A New Constitutional Order? Constitutional Politics and Text in the New Iraq: An Experiment in Islamic Democracy, 75 FordHaM L. REv. 883 (2006).

149. See Hirschl, supra note 112, at 1210. The way Hirschl frames the issue is telling:

First, the theocratic challenge has become a significant factor in world politics as well as constitutional law... . Second, the canonical literature concerning constitutionalism as an effective means for mitigating tensions in multi-ethnic or multi-linguistic states does not adequately address the theocratic challenge.... Third, the emergence of a new legal order-constitutional theocracy, which is now shared in one form or another by dozens of countries in the developing world-provides important insights into the sociopolitical role of constitutionalism in predominantly religious setrings.

Id. 
constitutionalism. Under the principles of this global transnational secular constitutionalism, religion has a subordinate (though respected) role. ${ }^{150}$ But whether one adopts Hirschl's perspective or mine, it is clear that something important has emerged within constitutionalist discourse. It is theocratic constitutionalism. ${ }^{151}$ Whether one considers it threatening and illegitimate, a challenge to the established universalizing normative constitutional order, or even a global threat to inwardlooking, traditional state-based constitutionalism, transnational or universalizing theocratic constitutionalism has emerged in its own right as another discursive framework for thinking about the legitimacy of the political constitutions of states.

Those deficiencies point to a different way of approaching such efforts at constitutionalizing religion. I have provided an alternative framework for considering the constitutional basis of theocracy.

First, the forms of "rule of law" constitutionalism are observed. The government constituted is in some great sense democratic. There is a significant element of separation of powers in the construction of the state apparatus. Second, the substantive elements of modern constitutionalism are also observed. Human rights are enshrined in the constitution and protected. The power to petition the government is preserved. Third, the power of the state and its governance organs are strictly limited... The difference-and a critical one to be sure-is the source of the norms constituting those boundaries of governance and the mechanisms for engaging with those norms. ${ }^{152}$

150. See Catá Backer, supra note 1, at 61 . "Within post War transnational constitutional ist systems religion was meant to be understood as just another right to protect. As against the universalizing framework of transnational constitutionalism, with its focus on human rights, democracy, participation and non-discrimination, religion was viewed as important but parochial." Id. at 36.

151. See Farish A. Noor, Blood, Sweat and Jihad: The Radicalization of the Political Discourse of the Pan-Malaysian Islamic Party (PAS) from 1982 Onwards, 25 Contemp. SE. AsIa 200 (2003). The Iranian revolution and constitutional settlement was decisive in its evolution.

Throughout the Islamic world, the socio-cultural and political impact of the Iranian revolution was profound. The Iranian revolution furnished the struggle of Sunni Islamist movements worldwide with renewed vigour and the tenor of their polemics and campaigns were heightened considerably. Islamist movements the world over redoubled their efforts to fight the twin world-devouring Satans (jahan-khor) - the Eastern and Western blocs--that were crushing the Muslims between them.

\section{Id. at 205.}

152. See Catá Backer, supra note 1, at 41-42 (theorizing the general framework of a non-A merican vetted Iraqi Constitution). 
The critical insight here is nexus between religion and government. Theocratic constitutionalism is grounded in notions similar to those that underlie transnational secular constitutionalism-that there is a set of universal values under the authority of which government is both constructed and limited. The form of that government must respect the dignity of individuals and avoid the elevation of any particular individual to a position in which he can use the authority of the state for personal ends. Government is meant to give effect to the rule of law. But the universal values which provide the framework within which governmental power may be asserted, and the framework for evaluating the relation of individual to state is provided by religion. As in transnational secular constitutionalism, the key lies in an embrace of the ideas that certain substantive principles of state construction-certain values-are both universal and mandatory, and that such values can only be supplied by an understanding of the Divine Word. Thus, for example, the "Universalism of Islam is an open proclamation to everyone-Muslim and non-Muslim alike-that communalism is totally alien to the spirit and philosophy of Islam." 153 The concept has roots in the West as well:

God is described as a lawgiver or prince, and styled just, merciful, etc., merely in concession to popular understanding, and the imperfection of popular knowledge; that in reality God acts and directs all things simply by the necessity of His nature and perfection, and that $\mathrm{His}$ decrees and volitions are eternal truths.... ${ }^{154}$

The effect is acute on core concepts—-for example democracy. 155 "Under tra-

So what would the non-American vetted Iraq Constitution look like? It might look like this: Islam is the source of all law. All law that contradicts Islam contradicts the Constitution. Authoritative Islamic law scholars must sit on the highest court, which merges secular and religious law. Individual, religious, democratic and human rights are respected within the context of the Islamic identity of the state. Group but not individual rights to conscience will be respected-a right to change religion will be permitted only to the extent permitted by the religious community from which the individual seeks to exit (best case) or permitted only in favor of conversion to Islam.

Id.

153. Chandra Muzaffar, Universalism in Islam, in Liberal Islam: A Source Book 155 (Charles Kurzman ed., 1998).

154. DE SPINOZA, supra note 103 , at 65.

155. See Catá Backer, supra note 1, at 57 ("This formal adherence and functional rejection of transnational constitutionalism is clearly evident in the reconstitution of democracy as a value of state constitution."). 
ditional transnational constitutionalism democracy served as a core value of state formation because it accorded with fundamental notions of fair governance and gave expression to the values of human dignity and equality." 156 The source of its legitimacy lies in the authority of the community of nations to develop and articulate global constitutional norms. ${ }^{157}$ "But within Iranian theocratic constitutionalism, and its American variant (as written into the Iraqi and Afghani and Iraqi [sic] constitutions), democracy serves as a sword, justifying national interventions and peculiarities that can trump other values, including those that are held to be fundamental by the community of nations. Thus the forms are observed by [sic] the substance is altered and redirected."158

Another key difference touches on human rights. And in this respect, legitimating universalist Islamic constitutionalism has been moving forcefully to institutionalize its own construction of these concepts in a way that distinguishes its basis from that developed by the community of nations through the organs of the United $\mathrm{Na}$ tions. ${ }^{159}$ Thus, it is not that theocratic constitutionalism, or its Islamic variety, fails to embrace human rights as a strict limit on the power of the state, it is that the understanding of the nature and character of those rights spring from foundationally different sources. Those differences can produce significant variation in application.

Transnational theocratic constitutionalism is not an illegitimate form of transnational secular (or global) constitutionalism. It is, instead, a competing system-and within the market for constitutional form, it is seeking to displace the post-1945 universalist constitutionalist system, based on the normative system presided over by the community of nations, with one in which the constitutions of states reflect the will of God as one or another faith communities understand that

156. Id.

157. See id.

158. Id.

159. Thus, for example, contrast the United Nations Universal Declaration of Human Rights, with the Universal Islamic Declaration of Human Rights (UIDHR). See, e.g., Ebrahim Moosa, The Dilemma of Islamic Rights Schemes, 15 J.L. \& RELIGION 185 (2001) "[T] he UIDHR explicitly states that in 'terms of our primeval covenant with God, our duries and obligations have priority over our rights.' This statement sharply distinguishes the Islamic rights-scheme from what is generally meant by secular 'human rights' where the term rights mean certain fundamental and unconditional entitlements simply on the grounds of being human." Id. at 196. The more formal Cairo Declaration emphasized both the similarities and differences between the approaches. Cairo Declaration on Human Rights in Islam, U.N. GAOR, World Conf. on Hum. Rts., 4th Sess., U.N. Doc. A/CONF.157/PC/62/ Add18 (Aug. 5, 1990). See discussion in Catá Backer, supra note 1, at 43. 
will and its earthly constitution, for example, through ulema ${ }^{160}$ or magisterium. ${ }^{161}$ The problem, then, is not one of correction, as Hirschl might suggest, but one of displacement. ${ }^{162}$ In the place of a set of related notions of constitutionalism, there has arisen another constitutionalist system, incompatible with and competing against that system for the allegiance of the community of nations.

As a consequence, much in Western constitutionalist discourse about theocratic constitutionalism - the Islamization of law - actually seeks to undo or subordinate that Islamization in the service of contemporary systems. ${ }^{163}$ The object is to privilege global secular values-generated as meta-law by the community of nations and central to the substantive element of transnational constitutionalism-over or through substantive constitutional values generated by Islam (or Buddhism, Christianity, Hinduism, or others). ${ }^{164}$ This takes a variety of forms. One focuses on the project of judicial reconstruction of Islamist constitutional provisions in the service of global secular norms. ${ }^{165}$ Another focuses on remaking

160. Ulema is the educated class of Muslim legal scholars as recognized within a particular territory. See generally Abdullah Saeed, The Official Ulema and Religious Legitimacy of the Modern Nation State, in Islam and Political Legitimacy 14, 14 (Shahram Akbarzadeh \& Abdullah Saeed eds., 2003) ("Two types of ulema exist: the official ulema and the non-official (independent) ulema. The official ulema are usually part of the state bureaucracy and are generally dependent on the state. The non-official ulema are usually outside the state bureaucracy."). For a discussion of the development of the ulema concept as critical to the construction of the Malay religious party, see Noor, supra note 151.

161. See The Vatican, Catechism of the Catholic Church 85 (2003) (explaining that " $[t]$ he task of giving an authentic interpretation of the Word of God, whether in its written form or in the form of Tradition, has been entrusted to the living teaching office of the Church alone. Its authority in this matter is exercised in the name of Jesus Christ").

162. This was, for example, well understood in the context of the Chechan wars against Russia.

After the war, radical Islamic groups began using religion as a basis for political reforms in the republic. They promoted the idea that the "desecrated and aggressive constitutionalism" of Russia and the West should be replaced by a constitutional theocracy, often quoting Dudayev's phrase, "[t] he power of Sharia law should be absolute and unlimited."

\section{Valery Tishkov, Chechnya: Life in a War-Torn Society 203 (2004).}

163. In a sense, that appears to be a consequence of projects like that of Noah Feldman. See Feldman, supra note 71; see also Feldman \& Martinez, supra note 148, at 885-90,918-19 (on the use of oppositional politics to craft a formally Islamic state that privileges traditional constitutionalist values).

164. Thus, for example, scholars tend to ask if theocratic constitutionalism can be used to vindicate secular constitutionalist values. See, e.g., Jennifer F. Cohen, Islamic Law in Iran: Can It Protect the International Legal Right of Freedom of Religion and Belief?, 9 CHI. J. INT'L L. 247, 266-73 (2008).

165. See generally Ran Hirschl, Constitutional Courts vs. Religious Fundamentalism: Three Middle Eastern Tales, 82 TEx. L. Rev. 1819 (2004). 
the competing substantive framework—in the case of Islam by substituting a "soft Islam" for homegrown varieties. ${ }^{166}$ Yet a nother focuses on invoking international communal standards to indict and delegitimize the substantive foundations of theocratic constitutionalism. ${ }^{167}$ But in doing so, these arguments recognize the incompatibility of such systems with contemporary transnational constitutionalist systems. ${ }^{168}$ But they do not examine that contrary constitutionalism on its own terms. ${ }^{169}$ That makes it harder to understand what is actually developing within constitutional theocracy. And for those who seek to meet the challenge of this rising system, for ways to meet that challenge within territories in which both systems seek to serve as the legitimate (and sole) basis of constitutional ordering.

If this is the case, then what might be the critical features of transnational theocratic constitutionalism? The Roman Catholic Pontiff, Benedict XVI, in a

166. Amitai Etzioni, Mosque and State in Iraq, PoL'y Rev., Oct./Nov. 2003, at 65, 68 ("Many have attempted to outline the features of a soft Islam in recent years, resulting in several typologies of liberal, modest, modern, and Euro-Islam that are contrasted with militant, virulent, and fundamentalist Islam.").

Such an Islam seeks to educate and encourage good conduct rather than coerce it, is open to reinterpretation on all matters but its core, welcomes participation by the members of the community rather than dictates from the mullahs, and spreads spiritually rather than by the sword.... The most effective way to develop such a conception is to embody it in new institutions for the whole world to see. Moreover, as we remain knee-deep in rebuilding Iraq, concrete questionsnot just matters of theory-must be faced.

Id. at 70. See generally Larry Catá Backer, Of Political States and "Soft" Religion as the Basis for State Organization, Law at the End of the Day, http://cbackerblog.blogspot.com/2007/07/of-political -states-and-soft-religion.html (July 16, 2007; 13:52 EST); Larry Catá Backer, Religion in the Service of the State: Schools of "Soft Islam" in Britain, Law at the End of the Day, http://lcbackerblog. blogspot.com/2007/08/religion-in-service-of-state-schools-of.html (Aug. 22, 2007. 21:20 EST).

167. "Even before the events of September 11, 2001 and the subsequent declaration of a 'war on terrorism,' articles on the relationship of 'Islam' to notions such as liberalism, democracy and pluralism were ubiquitous in the scholarly academy, to say nothing of the popular press. Much of this work, however, is either apologetic or polemical." Mohammad Fadel, The True, the Good and the Reasonable: The Theological and Ethical Roots of Public Reason in Islamic Law, 21 CAN. J.L. \& JURIS. 5, 5-6 (2008) (citing Ruud Peters, Islamic Law and Human Rights: A Contribution to an Ongoing Debate, 10 IsLam \& Christian-MusLim Rel. 5, 5 (1999) (noting that "[d]uring recent decades a host of publications have seen the light with titles like: 'Islam and $\mathrm{X}$ ' or ' $\mathrm{X}$ in Islam,' where $\mathrm{X}$ is typically a concept with positive connotations, such as democracy, peace, social justice, or women's rights")).

168. Etzioni, supra note 166, at 73 ("It follows that by promoting soft Islam we get two for the price of one: We promote a religion that is compatible with liberal democracy as well as one that can serve as an effective antidote to the fundamentalists.").

169. There are exceptions, of course. But even these come from a framework in which the examined system is both alien and in need of softening or control. 
recent address to the United Nations General Assembly, ${ }^{170}$ brilliantly underscored the congruence and competition inherent in the theocratic constitutionalist element. Benedict XVI's analysis is based (necessarily from the perspective of his own faith) in assumptions about the nature of the secular and the political that provide an interesting point for interrogation. ${ }^{171}$ In his own way, Benedict arrives at an understanding of the relationship between the religious and the political that in some ways mirrors that coming out of Qom.

Benedict starts the address with a bit of historical connection and first principles. He suggests that his views are not individual but institutional; it is not the man but the magisterium speaking. "As Pope John Paul II expressed it in 1995, the Organization should be 'a moral centre where all the nations of the world feel at home and develop a shared awareness of being, as it were, a "family of nations."”'172 He noted that " $[t]$ he founding principles of the Organization-the desire for peace, the quest for justice, respect for the dignity of the person, humanitarian cooperation and assistance-express the just aspirations of the human spirit, and constitute the ideals which should underpin international relations." 173

But being a moral center does not mean, for Benedict, the same thing as being the source of morality - even political morality. "Through the United Nations, States have established universal objectives which, even if they do not coincide with the total common good of the human family, undoubtedly represent a fundamental part of that good." ${ }^{\prime 74}$ Instead, Benedict suggests that the United Nations serves as a means through which a higher morality is served. This is especially so since all states are bound by this common and superior morality, which permits no unilateralism. These notions are expressed early in the address and in

170. His Holiness Pope Benedict XVI, Address of Benedict XVI to the Members of the United Nations General Assembly (Apr. 18,2008), available at http:/www.vatican.va/holy_father/benedict_ xvi/speeches/2008/april/documents/hf_ben-xvi_spe_20080418_un-visit_en.html.

171. See His Holiness Pope Benedict XVI, Encyclical Letter Spe Salvi of the Supreme Pontiff Benedict XVI to the Bishops, Priests and Deaconsmen and Women Religious and All the Lay Faithful on Christian Hope (Nov. 30, 2007), available at http://www.vatican.va/holy_father/benedict_xvi/ encyclicals/documents/hf_ben-xvi_enc_20071130_spe-salvi_en.html.

172. His Holiness Pope Benedict XVI, supra note 170, II 1 (citing His Holiness Pope John Paul II, Address to the General Assembly of the United Nations on the 50th Anniversary of its Foundation (Oct. 5, 1995), available at http://www.vatican.va/holy_father/john_paul_ii/speeches/1995/october/ documents/hf_jp-ii_spe_05101995_address-to-uno_en.html).

173. His Holiness Pope Benedict XVI, supra note 170, II 1.

174. Id. If 2. "This intuition was expressed as early as the fifth century by Augustine of Hippo, one of the masters of our intellectual heritage. He taught that the saying: Do not do to others what you would not want done to you 'cannot in any way vary according to the different understandings that have arisen in the world." Id. 
a manner that gently rebukes the United States and other powers for pushing their own political morality unilaterally over the higher morality articulated in part by the United Nations to which they are bound.

The United Nations embodies the aspiration for a "greater degree of international ordering," ... inspired and governed by the principle of subsidiarity, and therefore capable of responding to the demands of the human family through binding international rules and through structures capable of harmonizing the day-to-day unfolding of the lives of peoples. This is all the more necessary at a time when we experience the obvious paradox of a multilateral consensus that continues to be in crisis because it is still subordinated to the decisions of a few, whereas the world's problems call for interventions in the form of collective action by the international community. ${ }^{175}$

The higher morals to which the United Nations aspires, and which it can only express in part, is meant to serve the human family. States, by necessity can only reach that family partially. All states together, guided by the binding power of higher morality, are obliged to act in concert for the benefit of the human family. Politics, thus, serves morality. "Since rights and the resulting duties follow naturally from human interaction, it is easy to forget that they are the fruit of a commonly held sense of justice built primarily upon solidarity among the members of society, and hence valid at all times and for all peoples."176

The only divisions that ought to matter, it seems, are religious. ${ }^{177}$ For Benedict, the road is clear - it is not the practice of the community of nations that cre-

175. Id. I 2 (citing His Holiness Pope John Paul II, Sollicitudo Rei Socialis If 43 (Dec. 30, 1987), available at http://www.vatican.va/edocs/ENG0223/__P7.HTM).

176. His Holiness Pope Benedict XVI, supra note 170, I 8.

177. The gloss on this passage might be well provided from an interesting quarter-Benedict XVI's address to Catholic educators the day before the United Nations speech:

The Church's mission, in fact, involves her in humanity's struggle to arrive at truth. In articulating revealed truth she serves all members of society by purifying reason, ensuring that it remains open to the consideration of ultimate truths. Drawing upon divine wisdom, she sheds light on the foundation of human morality and ethics, and reminds all groups in society that it is not praxis that creates truth but truth that should serve as the basis of praxis. Far from undermining the tolerance of legitimate diversity, such a contribution illuminates the very truth which makes consensus attainable, and helps to keep public debate rational, honest and accountable. 
ates truth (for example, the Universal Declaration of Human Rights as a consensus among states and their traditions), but instead it is universal truth that binds states to an appropriate practice. Thus, Benedict XVI reasons " $[\mathrm{t}]$ ruth means more than knowledge: knowing the truth leads us to discover the good. Truth speaks to the individual in his or her entirety, inviting us to respond with our whole being." 78 Truth and its understanding of the absolute relation between good, evil, and action are bound up in "the vision of the Logos, God's creative Reason, which in the Incarnation, is revealed as Goodness itself. Far from being just a communication of factual data - 'informative' - the loving truth of the Gospel is creative and lifechanging-'performative' (cf. Spe Salvi, 2)."179 Legitimacy, faith, morals, and action-there is little room for the truths of the community of nations expressed merely in their actions-customary international law without morals is no law at all. In this sense, Benedict XVI strikes hard at the core of the construction of the global world order built from out of the ashes of the Second World War and enshrined in the secular internationalism of the United Nations.

In this context, as well, law assumes its principal role as instrument of moral rather than as thing in itself. Speaking of the United Nations Universal Declaration of Human Rights, Benedict XVI argues that " $[w]$ hen presented purely in terms of legality, rights risk becoming weak propositions divorced from the ethical and rational dimension which is their foundation and their goal." ${ }^{180}$ Rule of law ought not to infuse law with the power of Logos. For Benedict, the two are distinct, with law clearly subordinate and passive. "Human rights, then, must be respected as an expression of justice, and not merely because they are enforceable through the will of the legislators." 181 There is no place in Benedict's world construct for a higher customary law unless it be moral and universal and inspired by a faith tradition outside of the human group that seeks thus to legitimate its community. ${ }^{182}$

His Holiness Pope Benedict XVI, Address to Catholic Educators, II 11 (Apr. 17, 2008), available at http://www.vatican.va/holy_father/benedict_xvi/speeches/2008/april/documents/hf_ben-xvi_ spe_20080417_cath-univ-washington_en.html. This mission ties faith, reason and community within a tightly bound web. "Church's primary mission of evangelization, in which educational institutions play a crucial role, is consonant with a nation's fundamental aspiration to develop a society truly worthy of the human person's dignity." Id.

178. Id. $\mathbb{1} 12$.

179. Id.

180. His Holiness Pope Benedict XVI, supra note 170 , ๆ 8.

181. Id.

182. See Larry Catá Backer, Reifying Law_Government, Law and the Rule of Law in Governance

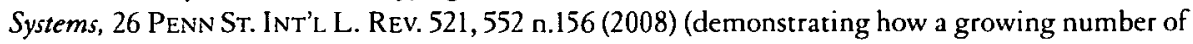
Americas are coming more to share Benedict's worldview as they shed themselves of their original 
Matters of morality, then, cannot be left to the expression of the political will of states, even expressed democratically. ${ }^{183}$ "Discernment, then, shows that entrusting exclusively to individual States, with their laws and institutions, the final responsibility to meet the aspirations of persons, communities and entire peoples, can sometimes have consequences that exclude the possibility of a social order respectful of the dignity and rights of the person." 184 Benedict thus rejects the basic notion of the sort of constitutionalism on which eighteenth and nineteenth century democratic states were founded - the idea that the people are the source of rights and duties and may bind themselves to those rights and duties, however discerned. But Benedict has something else in mind. Speaking of the Universal Declaration of Human Rights, he suggests that the norms described therein "are based on the natural law inscribed on human hearts and present in different cultures and civilizations. Removing human rights from this context would mean restricting their range and yielding to a relativistic conception, according to which the meaning and interpretation of rights could vary and their universality would be denied in the name of different cultural, political, social and even religious outlooks." ${ }^{185}$ For Benedict, then, the proliferation of "viewpoints must not be allowed to obscure the fact that not only rights are universal, but so too is the human person, the subject of those rights." 186

understanding of law as shared communal expression and move to a more imperial view of law as sourced in a superior body).

183. See generally His Holiness Pope Benedict XVI, supra note 171, IT 42.

The atheism of the nineteenth and twentieth centuries is-in its origins and aims-a type of moralism: a protest against the injustices of the world and of world history. A world marked by so much injustice, innocent suffering, and cynicism of power cannot be the work of a good God. A God with responsibility for such a world would not be a just God, much less a good God. It is for the sake of morality that this God has to be contested. Since there is no God to create justice, it seems man himself is now called to establish justice. If in the face of this world's suffering, protest against God is understandable, the claim that humanity can and must do what no God actually does or is able to do is both presumptuous and intrinsically false. It is no accident that this idea has led to the greatest forms of cruelty and violations of justice; rather, it is grounded in the intrinsic falsity of the claim.

Id.

184. His Holiness Pope Benedict XVI, supra note 170, I 10.

185. Id. at II 6. See generally His Holiness Pope Benedict XVI, supra note 171, If 42 ("A world which has to create its own justice is a world without hope. No one and nothing can answer for centuries of suffering. No one and nothing can guarantee that the cynicism of power-whatever beguiling ideological mask it adopts-will cease to dominate the world.").

186. Id. 
And thus the place of religiously-derived morals should be at the pinnacle of the construction of global political norms to which the laws of all states ought to be subject: "Refusal to recognize the contribution to society that is rooted in the religious dimension and in the quest for the Absolute-by its nature, expressing communion between persons-would effectively privilege an individualistic approach, and would fragment the unity of the person." ${ }^{187}$ This idea-that the expression of the communal will and the search for the Absolute is both necessary and requires the intervention of religious communities (and principally their governance and interpretive institutions - their magisteria) in shaping the understanding of the normative dimensions of law, also requires a broadening of religious participation in internal politics. In a manner sounding much like American supporters of soft Islamic state constitutions in Iraq and Afghanistan (but presumably not in the United States), Benedict proposes that "[ $t$ ]he full guarantee of religious liberty cannot be limited to the free exercise of worship, but instead it has to give due consideration to the public dimension of religion, and hence to the possibility of believers playing their part in building the social order." ${ }^{88}$ Separation of Church and State is, for Benedict, as false a construct as the separation of faith from reason.

There is no hidden meaning here. Benedict XVI invites a consideration of Spe Salvi and its relation to the suggestions he makes to the assembled ministers at the United Nations. He reminds the secular powers of their joined task of secular and religious authority - that the task of every generation to "engag[e] anew in the arduous search for the right way to order human affairs.... That is why the Church is happy to be associated with the activity of this distinguished Organization, charged with the responsibility of promoting peace and good will throughout the earth."189 For this joint task, Benedict would remind his audience of his view of evil-the construction of interpretive norms beyond religion. "We have all witnessed the way in which progress, in the wrong hands, can become and has indeed become a terrifying progress in evil." 190 An outside hand is necessary-but that hand cannot be the community of nations, it must be the divine order administered through the instruments of divine will, institutionally constructed, with an oversight power on earth.

And so we come to the great contribution of this speech, at least for the construction of the parameters of a rule of law-based theocratic constitutionalism as a

187. His Holiness Pope Benedict XVI, supra note 170, I 11.

188. Id.

189. Id. at $\mathbb{I} 14$.

190. His Holiness Pope Benedict XVI, supra note 171, I 22. "If technical progress is not matched by corresponding progress in man's ethical formation, in man's inner growth (cf. Eph 3:16; 2 Cor $4: 16$ ), then it is not progress at all, but a threat for man and for the world." Id. 
legitimate normative system. It seems that political legitimacy requires an adherence to legitimate substantive norms, which may only be derived from those universal truths beyond the reach of individuals or even communities of the faithless. Only faith communities can legitimately provide those norms-a notion echoed elsewhere by the faith communities of Islam and institutionalized in constitutions from that vary in form from that of Saudi Arabia to that of Iran. ${ }^{191}$ But Benedict is suggesting something more than the control of morals within states. He suggests, as a matter of international relations, that institutionalized religion ought to serve as autonomous participants along with states in the construction of those universal norms that might legitimately bind states in their external as well as internal relations.

In a manner that is consistent with her contribution in the ethical and moral sphere and the free activity of her faithful, the Church also works for the realization of these goals through the international activity of the Holy See. Indeed, the Holy See has always had a place at the assemblies of the Nations, thereby manifesting its specific character as a subject in the international domain. As the United Nations recently confirmed, the Holy See thereby makes its contribution according to the dispositions of international law, helps to define that law, and makes appeal to it. ${ }^{192}$

According to this wisdom, it is time now for institutionalized religion to meet its obligations within the political sphere-and not just the Holy See. Faith communities-Jewish, Muslim, Buddhist, Non-Catholic Christian and the likemust also take their place as subjects of international law and participants therein. In the absence of that ecumenism, the Logos might be distorted through the error of individuals who do not represent the totality of faith on Earth. Benedict believes that " $[\mathrm{d}]$ iscernment, that is, the capacity to distinguish good from evil, becomes even more essential in the context of demands that concern the very lives and conduct of persons, communities and peoples." 193 For that purpose, "a vision of life firmly anchored in the religious dimension can help to achieve this, since recognition of the transcendent value of every man and woman favours conversion of heart, which then leads to a commitment to resist violence, terrorism and war, and to promote justice and peace."194

191. See Catá Backer, supra note 1.

192. His Holiness Pope Benedict XVI, supra note 170, I1 12.

193. Id. II 9.

194. Id. II 10. 
Benedict XVI, of course, does not mean to lobby vigorously on behalf of other faith communities - he is charged with the triumph of his own. But his ideas-as Logos-might necessarily proceed beyond the mouth of the man who utters them. Yet he does wind up suggesting a place for formally-constituted faith communities at the political table as subjects of international law. Before dismissing these ideas as unusual, consider how much closer the world order is becoming to legitimate autonomous religious participation in political norm construction after 2001 than it was before then. It is not for nothing that the greatest source of political vigor in this century has sought power in its connection with something outside of the community it seeks to bind. From Chinese scientific determinism to Catholic Logos, Islamic Shar'ia, Jewish law, all may someday share a place at the political table as critical actors in the construction of substantive higher law, and all may invoke the protection of the communities of the faithful in the preservation of their communities and the territories served by them.

Is it possible to generalize the insights drawn from Benedict and the Islamization of constitutional law into an understanding of constitutionalism that is theocratic, and not merely an Islamic wrinkle on theories of constitutionalism? Is it possible to suggest a form by which the basic values framework of theocracy can be fused with the constitutionalist turn of this century? Theocratic constitutionalism is a worldview positing the construction of states subject to law but grounded in the values of a particular religious tradition. ${ }^{195}$ That tradition is both universalizing and supranational. ${ }^{196}$ Conformity to the substantive norms of theocratic

195. See Clifford Geertz, The Inter Pretation of Cultures 123 (1973) (arguing that theocratic constitutionalism represents the legalization of the anthropological perception that "the importance of religion lies in its capacity to serve, for an individual or for a group, as a source of general, yet distinctive, conceptions of the world, the self, and the relations between them, on the one hand-its model of aspect-and of rooted, no less distinctive 'mental' dispositions-its model for aspect-on the other").

196. John L. Esposito \& John O. Voll, Islam and Democracy 23 (1996) (“Despite the great dynamism and diversity among contemporary Muslims in terms of political views, there are core concepts that are central to the political positions of virtually all Muslims. What varies is the definition of the concepts ...."). Like conventional constitutionalism,

[w] hat varies is the definition of the concepts-not recognition of the concepts themselves. Abu al-Ala al-Mawdudi, a significant Sunni Muslim thinker who lived in British India and then independent Pakistan, and who established the major South Asian Islamic revivalist organization, the Jamaat-i-Islami, stated that the "political system of Islam has been based in three principles, viz: Tawheed (Unity of God), Risalat (Prophethood) and Khilafat (Caliphate)."

Id. (citing SAYYID ABUL A'LA MAUdUd, IsLAmIC WAY OF Life 40 (Khurshid Ahmad trans., 1967)). 
constitutionalism requires conformity to those religious norms with respect to which the members of each state may participate but which no state controls. But though it privileges the universal as framework, it also leaves room for context and difference. ${ }^{197}$ Still, as with secular constitutionalism, its ideals can sometimes be used to mask illegitimate objectives. ${ }^{198}$

It is within this values system that apostasy becomes plausible as a constitu-

197. See, e.g., Abdullahi Ahmed An-Na'im, Human Rights in the Muslim World: Socio-political Conditions and Scriptural Imperatives, 3 Harv. Hum. RTs. J. 13, 15 (1990) (compatibility of Islam and secular global human rights regimes). As Carl Brown has recently noted:

The scholarly debate describing contemporary Muslim states and societies and predicting future developments has produced a spectrum of options. At one end are those insisting that Islam is the major factor explaining the situation of today's Muslims. Islam has so thoroughly molded them that they must be analyzed by different criteria. Islam is sui generis. At the other end of the spectrum are found those maintaining that basic political, economic, and social factors-such as are found in all societies- account for the problems and the prospects of today's Muslim world. If the reality of daily life in these Muslim countries were more sanguine and secure, the Islamists would have scarcely a following.

L. Carl Brown, Religion and State: The Muslim Approach to Politics 179 (2000); see also Sally Engle Merry, Constructing a Global Law-Violence Against Women and the Human Rights System, 28 LAW \& Soc. INQUIRY 941, 944-45 (2003) (exploring Palestinian women's gender rights and Islam within the peculiar context of Gaza).

198. In the context of Islam that problematizes what is sometimes written about as the "Arabization" of political discourse, especially in conjunction with the Islamization of politics. Arabization is ethnocentric, racist, and assimilationist in ways that are not necessary to Islamization. See, e.g., Aihwa Ong, State Versus Islam: Malay Families, Women's Bodies, and the Body Politic in Malaysia, in Bewitching Women, Pious Men: Gender and Body Politics in Southeast Asia 159, 167, 177 (Aihwa Ong \& Michael G. Peletz eds., 1995) (Arabization of Malaysian family roles); Norman A. Stillman, The Jews of Arab Lands in Modern Times 173 (1991) (on Arabization and the effects on religious minorities); Michael J. Kelly, The Tricky Nature of Proving Genocide Against Saddam Hussein Before the Iraqi Special Tribunal, 38 Connell INT'L L.J. 983, 989 (2005) (with respect to ethnic cleansing in Iraq, "[i]n the north, the 'A rabization' of oil-producing areas meant eviction of Kurdish farmers, who were replaced with Arab tribesmen."); William L. Saunders Jr. \& Yuri G. Mantilla, Human Dignity Denied: Slavery, Genocide, and Crimes Against Humanity in Sudan, 51 Catr. U. L. Rev. 715, 716 (2002) (forced Islamization in Darfur) (citing U.S. Dept. of State, Human Rights REPORTS FOR 1999-SUdAN, (2000), available at http://www.state.gov/www/global/humanrights/1999_hrp_ report/sudan.html); Sarah L. Dygert, Note, Eradicating Sudanese Slavery: The Sudanese Government and the Abuse of Islam, 3 Regent J. Inr'L L. 143 (2005); Matthew J. Fery, Case Note, Determining Better Standards for Firm Resettlement, Judicial Discretion, and Immigration Administrative Practice-Diallo v. Ashcroft, 381 F.3d 687 (7th Cir. 2004), 31 U. Day ton L. Rev. 505, 509 (2006) ("The governments of Mauritania and Senegal, as early as 1989, began a process of "Arabization,' whereby the Mauritanian government would deport black citizens to Senegal." (citing Human Rights Watch, Human Rights Watch World Report 1990-Mauritania, available at http:// www.hrw.org/reports/1990/WR90/AFRICA.BOU-06.htm\#P339_74389)). 
tionalist tool. For systems in which political ordering is grounding in religious frameworks, religious affiliation is expanded to become something more than a religious affiliation-it serves also as a mark of political affiliation. And more than that, religious affiliation becomes the marker for dull political citizenship. It is in this context that Islamic theocracies-whether or not constitutionalist states could view apostasy as a political act and not merely a change of conscience directed by a divine power. ${ }^{199}$ For a state founded on the belief in the eternal and transcendent superiority of a set of religious imperatives, a community of believers is essential for the operation of the state under those divine principles. Conversion or apostasy represents not merely a change of faith but also an affirmation of a rejection of the substantive political values (divinely ordained to be sure) on which the state is grounded. While religious minorities might be tolerated, they are not permitted to grow nor to threaten the state. ${ }^{200}$ For transnational constitutionalism, such a conceptual framework is anathema. ${ }^{201}$

That worldview has an ordering element. It judges constitutions as legitimate and illegitimate in accordance with their compliance with the basic precepts and normative framework that is embraced as legitimate. It sees itself as the greatest source of normative legitimacy and alternative perspectives as flawed. Like other forms of constitutionalism, theocratic constitutionalism's taxonomy reinforces an underlying normative structure. The normative element of theocratic constitutionalism carries with it a certain authentic or legitimating meta-ideology. That

199. Even Islamic modernist scholars "read the normative texts that appear to contemplate execution of apostates as referring to acts of treason rather than a change in a person's conviction" and thus see the connection between religion and politics, reading the connection through to the early interpretative texts. Mohammad H. Fadel, Public Reason as a Strategy for Principled Reconciliation: The Case of Islamic Law and International Human Rights Law, 8 CHI. J. INT'L L. 1, 19 (2007).

200. See, e.g., Lina Joy v. Majlis Agama Islam Wilayah Persekutuan \& Anor, [2007] 4 MLJ 585 (F.C.) (Malay.) [Lina Joy v. Federal Territory Islamic Council \& Others, [2007] 4 MLJ 585 (F.C.)], available at http://www.accin-badailies.org/Lina\%20Joy.pdf. The case involved a woman, born of Malay parents, who sought to change her name and religious affiliation on her national identity card on her conversion to Christianity. The Malay constitution defines a Malay as a person of a distinct ethnic parentage who is a Muslim (art. 160), but also appears to grant religious freedom to all citizens (art. 11(1)). The argument centered around whether she could freely declare a change of faith or whether she was bound by a determination of an Islamic religious court of her formal religious membership (and thus her classification as a Malay). For a discussion in the context of Malaysian constitutionalism, see infra text and notes 351-378. See also Nurjaanah Abdullah \& Chew Li Hua, Legislating Faith in Malaysia, 2007 Sing. J. Legal Stud. 264 (2007).

201. See generally Donna E. Arzt, Religious Human Rights in Muslim States of the Middle East and North Africa, 10 EMORY INT'L L. REv. 139, 144-45 , 149-54 (1996). For an application in the context of Indian constitutionalism, see Seval Yildirim, Expanding Secularism's Scope: An Indian Case Study, 52 Aм. J. CомP. L. 901 (2004). 
meta-ideology is easy to find, though its implementation and contours are as difficult to discern as those of secular transnational constitutionalism. Religion provides the ideology that serves as the grounding for understanding and applying notions of right and justice - of actions that may be taken and those which must be forbidden and of the role of the state in furthering the obligations of community and individuals. There is much similarity at its core between universalist secular and theocratic constitutionalism, at least in its institutional distribution of constitutive power above the state. ${ }^{202}$

Lastly, theocratic constitutionalism has an implementation element derived from its ideologically-constrained organizational basis. Rule of law is strong within theocratic constitutionalism - avoidance of arbitrary action by the state or its servants, action in conformity with law, and most importantly, limits on lawmaking. The state is not despotic; it must conform to law, and its servants may not exceed the authority vested in it by the constitution as bounded in turn by the substantive framework within which the constitution is cast. The focus has been on process and substantive provisions. Here is where the theocracy part of constitutionalism comes into prominence, for those limits are not ultimately in the control of the apparatus of state but in those elites authentically vested with authority over the basic texts and rule interpretation of the religion privileged through the constitution.

Accountability of state officials is guaranteed through the constitution; accountability of those who hold the power to interpret and apply the basic principles of theocratic constitutions is left to the religious organization. That organization is supranational in scope-faith communities and their institutional structures have gone global. Its members belong to global communities of the faithful constituted as autonomous groups. Though state-based institutions may flourish, the obligation to avoid too great a deviation from the basic rules of the global religious body keeps all the arbiters of rules and conduct in check. There is thus both an element of contextualization - the ability of local religious elites to naturalize the universal principles of normative religion within their territoriesand universalism, as the adherence to the framework structures of the substantive system. Protection of the rights and dignity of individuals are preserved, but within the framework of the understandings of those terms within religious

202. See, e.g., Fulton J. SheEn, Communism And the Conscience of THE West 76 (1948) (Comparing seemingly incompatible universalist visions of constitutionalism held by Christianity and Marxism, Sheen argued that "[s]o much is communism a secularization or dedivinization of Christianity that it can be presented as an ersatz for Christian doctrines."). 
law. ${ }^{203}$ Membership in the polity is tied not to citizenship so much as to membership in the constitutionalized religious community. For the others, citizenship comes without a power to participate in the construction of meta-rules that define the power relationships and behavior norms of the state.

\section{But Are Religious Constitutions Evidence of a Distinctive Theocratic Constitutionalism? An Application of Theory to Reality}

The fact that religion can claim pride of place within a constitutionalist enterprise does not mean that all constitutions with a reference to religion fall within the emerging traditions of theocratic constitutionalism. Just as one can have constitutions without constitutionalism, ${ }^{204}$ one ought to be able to distinguish between constitutions with theocratic elements and constitutions that are legitimately theocratic constitutionalism. Those elements include an embrace of the fundamental ideal that government ought to have limited power. Those limitations are structural and political. Political limitations include popular sovereignty, political participation by citizens, and accountability by agents of the state for their conduct. Structural limitations are also grounded in rule of law assumptions. These include process limitations to guard against arbitrary actions or other conduct that are not grounded in law, and process for the legitimate exercise of state power. It also includes substantive rules for the exercise of state power. These include respect for the rights of individuals and the institution of a moral or ethical basis for state behavior grounded in what is right and just. The source of both process and substantive limits are not found in local practice but in a set of universal values to which the state and its organs are bound-the universal values and legal rules of religion.

203. Thus, for example, the concept of democracy might itself be given its "truer" meaning within the Islamic normative framework like this:

The theocracy built up by Islam is not ruled by any particular religious class but by the whole community of Muslims including the rank and file. The entire Muslim population runs the state in accordance with the Book of God and the practice of His Prophet. If I were permitted to coin a new term, I would describe this system of government as "theo-democracy", that is to say a divine democratic government, because under it the Muslims have been given a limited popular sovereignty under the suzerainty of God.

EsPOSITO \& VOLL, supra note 196, at 24 (quoting and discussing SAYYID ABul A'LA MAUDUd, ISLAMiC WAY OF LifE 40 (Khurshid Ahmad trans., 1967)).

204. See supra text accompanying notes 15-17. 
This Part presents a preliminary excursion into the constitution of theocratic constitutionalism. It looks to two models at either end of the constitutionalist spectrum. The first of these, Iran, presents a model of constitution making that is legitimate within the context of theocratic constitutionalism. Along with Iran, this part examines some issues in constitutional projects that fall imperfectly within the model-for this purpose it looks to Afghanistan's post-conflict constitution. So understood, that document does not present a legitimate foundation of government under principles of universalist theocratic constitutionalism. The second, the constitution of Saudi Arabia, evidences a theocratic constitution without constitutionalism. It ends by considering whether religion-based constitutions can fall into a constitutionalist limbo-neither secular nor theocratic constitutionalism. For that purpose, it looks to the constitutional projects of Pakistan and Egypt. The focus of the analysis is on formal constitutions. ${ }^{205}$ These constitutions suggest the dangers of substantive values conflicts in the evolution of constitutionalist states. The analysis also suggests the utility of the model of constitutionalism developed here. The problem with constitutionalist discourse in these states is that it does not touch on adherence to the basic framework of legitimating constitutionalism but on a contest for supremacy between competing value systems through which Egyptian, Pakistani, and other constitutionalism might be expressed and implemented. Lastly, the Part suggests the ways in which constitutionalism-based analysis can be applied outside the context of Islamic theocratic constitutionalism by looking briefly at the question of Buddhist theocracy in Sri Lanka.

\section{A. Theocratic Constitutionalism-The Cases of Iran and Afghanistan 1. Iran}

Iran presents an example of a well-developed system of theocratic constitutionalism. If for no other reason this system presents the greatest challenge to the values on which its competitor-secular transnational constitutionalism-is

205. I concede the importance of constitutional application. Constitutionalism, at least in its aspect as taxonomy, is concerned with the possibility of sham constitutions and the articulation of constitutionalist values there is no intention to apply. See Larry Catá Backer, Democracy Part XII: On Sham Democracies, Law at the End of the Day, http://lcbackerblog.blogspot.com/2008/06/ democracy-part-xii-on-sham-democracies.html (June 27, 2008, 16:22 EST) (examining HUMAN Rights Watch, Human Rights Watch WORLD RePORT 2008 (2008), available at http://hrw.org/ $\mathrm{wr} 2 \mathrm{k} 8 / \mathrm{pdfs} / \mathrm{wr} 2 \mathrm{k} 8$ _web.pdf). These issues enrich but are not necessary for the object of this article-to sketch out a working understanding of a legitimate formal constitutionalism grounded in values other than those developed through secular pluralist international political activity, even one skewed to the interests of the most powerful American and European states. 
based. Iran's theocratic government is not merely the imposition of a religious state without limits, but instead suggests a principled basis of state organization through law, the object of which is to secure the benefits of a specific (though perhaps odious to nonbelievers) set of legitimate (to believers) normative values.

That political agenda can be simply stated: Islam provides a comprehensive sociopolitical system valid for all time and place. Thus, God is the sole legislator. Government is mandated in order to implement God's plan in this world. Individual believers are not permitted simply to suffer unjust rule in silence. They must actively work to realize God's plan in this world. The only acceptable form of this Islamic government is that directed by the most religiously learned. This is the guardianship of the faqih (velayat-e faqih). ${ }^{206}$

This is meant to be a rule of law ordering. ${ }^{207}$ This ordering is well-represented in the Constitution of the Islamic Republic.

The government constituted pursuant to the Iranian Constitution is in some great sense democratic. ${ }^{208}$ There is a significant element of separation of powers in the construction of the state apparatus. ${ }^{209}$ Second, the substantive elements of modern constitutionalism are also observed. ${ }^{210}$ Human rights are enshrined and protected in the constitution. ${ }^{211}$ The power to petition the government is preserved. ${ }^{212}$ The Iranian Constitution creates a system of government grounded in rules and separation of powers. The legislative power is vested in representatives

206. BROWN, supra note 197, at 172. The work also has an excellent discussion of the development of what would become Khomeini's politico-religious philosophy, including its xenophobia and anti-Jewish paranoia. See id. at 161-74.

207. “'Since Islamic government,' Khomeini asserted, 'is a government of law, those acquainted with the law, or more precisely, with religion-i.e., the fuqaha-must supervise its functioning. It is they who supervise all executive and administrative affairs of the country, together with all planning."' Id. at 172.

208. See Qanuni Assassi Jumhuri'i Isla'mai Iran [The Constitution of the Islamic Republic of Iran] [1980] arts. 6-8 [hereinafter Iranian Constitution of 1979]. However, it is subject to the ultimate limitations of the supreme religious leader. See id. art. 5.

209. See id. arts. 56-63. Again, this is in accordance with the limitations of Islam generally as exercised through the religious leader pursuant to Article 5 and Articles 90-99.

210. See id. arts. 19-55.

211. See id. arts. 19-42.

212. See id. arts. 26-27. These articles a re ambiguous regarding the extent of the protections offered. $I$. 
of the people, ${ }^{213}$ whose actions are constrained within a system of institutionalized and nominally democratic legislation adopted in accordance with constitutional requirements. ${ }^{214}$ Like modern constitutions it also imposes limits on power that can be exercised by the state. ${ }^{215}$ But constitutionally granted authority may only be exercised within the limits of the legal framework of Islam. Islam is not only normatively foundational but also constituted as a foundational system of legal organization. ${ }^{216}$ It is not a supplement but a substitute for the constitutionalist values represented by the international system and the values generated by the community of states. Thus, for example

[d]uring a meeting of the United Nations Human Rights Committee in 1982 investigating reports of state-sponsored murder and torture, the leader of the Iranian delegation was questioned about Iran's view on the United Nations Universal Declaration of Human

Rights. Sayed Hadi Khosrow-Shahi, the leader of the delegation,

213. See id. art. 57 (stating that the powers of government are vested in the legislature, judiciary, and executive); art 58 (stating that the legislative functions are to be exercised through the Islamic Consultative Assembly).

214. The legislative power is then elaborated. See id. arts. 62-99.

215. The substantive limitations on state power are elaborated in Chapter III of the Constitution, Articles 19-31. These mimic the standard description of basic rights in post-war constitutions. But rather than being grounded in transnational constitutiona list principles, these rights are grounded "in conformity with Islamic criteria." Id. art. 20 (equal protection of the laws); art. 21 (rights of women); art. 24 (press freedom except when "detrimental to the fundamental principles of Islam"); art. 27 (public gatherings, same as art. 24); art. 28 (right to choose occupation if "not contrary to Islam or the public interest").

216. See e.g., id. art. 12 ("The official religion of Iran is Islam and the Twelver Ja'fari school [in usual al-Din and fiqh], and this principle will remain eternally immutable."). The legalist nature of Islam within Iranian constitutionalism is further refined in Article 12: “Other Islamic schools, including the Hanafi, Shafi'i, Maliki, Hanbali, and Zaydi, are to be accorded full respect, and their followers are free to act in accordance with their own jurisprudence in performing their religious rites." Id. The authority of these legal schools are legitimized through the constitution as well.

These schools enjoy official status in matters pertaining to religious education, affairs of personal status (marriage, divorce, inheritance, and wills) and related litigation in courts of law. In regions of the country where Muslims following any one of these schools of fiqh constitute the majority, local regulations, within the bounds of the jurisdiction of local councils, are to be in accordance with the respective school of fiqh, without infringing upon the rights of the followers of other schools.

Id.; see also id. (sovereignty of Qur'onic justice); art. 2 (belief in "Divine revelation and its fundamental role in setting forth the laws"); art. 4 (need to base all laws and regulations on Islam). The critical provision is Article 5, which vests ultimate authority on a religious leader. 
replied that Iran believed in the "supremacy of Islamic laws, which are universal"' and when a law, such as the Universal Declaration of Human Rights, comes in conflict with Islamic laws, Iran would "choose the divine laws." 217

This constitution is not imposed from above but represents an act of will of the people - a recognition, freely embraced — of the appropriate form of political organization. ${ }^{218}$ The privileging of Islam in the political context is absolute. "This principle applies absolutely and generally to all articles of the Constitution as well as to all other laws and regulations, and the fuqaha' of the Guardian Council are judges in this matter." ${ }^{219}$ For that purpose, the constitutional systems creates an institutional framework for religious oversight of political activity, ${ }^{220}$ at the apex of which stands the Guardian Council, 221 "with a view to safeguard the Islamic ordinances and the Constitution, [and] in order to examine the compatibility of the legislation passed by the Islamic Consultative Assembly with Islam."222 Indeed, the representative legislature "does not hold any legal status if there is no Guardian Council in existence."223

There is no popular right to interrogate and alter the formulation of the basic substantive norms on which political governance is founded-unless one is part of the instructional structure of the religion. Shi'a Islam, it seems, has its own magisterium ${ }^{224}$ - but one that serves both a political and religious function. For all others, there is obedience. ${ }^{225}$ Thus, for example, in the section of the Constitution elaborat-

217. Reimer, supra note 112 , at 360.

218. See Iranian Constitution of 1979 art. 1. ("The form of government of Iran is that of an Islamic Republic, endorsed by the people of Iran on the basis of their long-standing belief in the sovereignty of truth and Qur'anic justice, in the referendum of ... [March 29-30, 1979] through the affirmative vote of a majority of $98.2 \%$ of eligible voters, held after the victorious Islamic Revolution led by the eminent marji' al-taqlid, Ayatullah al-Uzma Imam Khumayni.").

219. Id. art. 4.

220. Said Saffari, The Legitimation of the Clergy's Right to Rule in the Iranian Constitution of 1979, 20 BRit. J. MiddLe E. Stud. 64, 82 (1993).

221. Iranian Constitution of 1979 art. 91.

222. Id.

223. Id. art. 93.

224. See infra text accompanying note 264.

225. Republican principles are still consonant with this system-it is just that the interrogation of basic norms found in Islam are now outside the bounds of political discourse, and with respect to those, the citizen must yield to the authoritative spokesperson for the superior religious system. "[T] I Islamic government is based on an ideology different from that of a democratic republic. What ... is indeed appropriate for a democratic republic ... fails to meet the requirements of Islam." Saffari, supra note 220, at 65, 73 (on the religious basis of priestly government in Shi'a Islam). See generally Catá Backer, supra note 40. 
ing the rights of national sovereignty, the Constitution starts with the declaration that "absolute sovereignty over the world and man belongs to God.... The people are to exercise this divine right in the manner specified in the following articles."226 But of course, the people, at least within Islam, do have a significant and complex role in the elaboration and application of that system, both as applied to the constitution of the state and in its role as legal code governing every aspect of life. ${ }^{227}$

The Iranian theocratic constitution resembles modern constitutions and adheres to the current pattern of modern constitutionalism in its form and objectivesto formulate a system of governance based on legitimating principles and authoritative values. It adheres to thick "rule of law" constitutionalism. The power of the state and its governance organs are strictly limited. In this sense, the Iranian constitution follows emerging models of transnational constitutionalism. The difference-and a critical one to be sure- is the source of the norms constituting those boundaries of governance and the mechanisms for engaging with those norms.

\section{Afghanistan}

The Afghani Constitution also provides an example of a constitutional settlement that looks to principles of theocratic constitutionalism for its legitimacy. ${ }^{228}$ Its preamble suggests a certain internationalism in the values underlying the constitutional project. ${ }^{229}$ Yet, the lens through which such substantive protections are

226. Iranian Constitution of 1979 art. 56.

227. The concept and operation of the ummah is well-known within Islam. While its actual invocation and effect are highly contested and fluid, it does provide at least in theory a vehicle through which the people can, as a whole, directly intervene in the elaboration and application of the unalterable divine command. In reality, of course, the ummah system is tempered by an ancient and complex system of elaboration by scholars and others, the size and power of whose following, may also be invested with a certain legitimacy and authority. See generally Christopher Stuart, From "Mother of the World" to the "Third World" and Back Again: The Harmonization Cycle Between Islam and the Global Economy, in Harmonizing Law in an ERA of Globalization 279 (Larry Catá Backer ed., 2007) (discussing the commercial success of the Islamic world in relation to its integration with the rest of the world).

228. Constitution of Afghanistan pmbl., available at http://www.junbish.org/constitution_of_ afghanistan__yea.htm.

229. Id. The Preamble appears to place Afghanistan strongly within the transnational constitutionalist camp. It speaks to a grounding in global values constitutionalism, for example:

Observing the United Nations Charter and respecting the Universal Declaration of Human Rights, For consolidating national unity, safeguarding independence, national sovereignty, and territorial integrity of the country, For establishing a government based on people's will and democracy, For creation of a civil society free of oppression, atrocity, discrimination, and violence and based on the rule of 
seen are not those of global constitutionalism but of eternal universalism of a relgious foundation. ${ }^{230}$ Thus, "[ $\left.\mathrm{t}\right]$ he religion of the state of the Islamic Republic of Afghanistan is the sacred religion of Islam." ${ }^{231}$ The Afghani Constitution builds strong protections against derogation from its core substantive provisions. "The provisions of adherence to the fundamentals of the sacred religion of Islam and the regime of the Islamic Republic cannot be amended." 232 Islam does not so much reject a fundamental rights value system as incorporate it within the normative framework of Islam. Despite suggestions to the contrary, it inverts the hierarchy of values - religion is not interpreted as an object of fundamental rights; instead, fundamental rights are interpreted as an object of Islam. ${ }^{233}$ "In Afghanistan no law can be contrary to the beliefs and provisions of the sacred religion of Islam." ${ }^{234}$ For those from different religious traditions, there is conformity to an Islamic worldview within which a certain measure of toleration is possible. This, of course, parallels the limits to toleration within conventional transnational constitutional systems of beliefs and practices, which might be deemed threatening to the politico-legal order. ${ }^{235}$ "Followers of other religions are free to exercise their faith and perform their religious rites within the limits of the provisions of law."236 But threats to the religious basis of the legal order-including efforts to pry Muslims from their faith, are less tolerated. ${ }^{237}$ Indeed, the constitution imposes on the

law, social justice, protection of human rights, and dignity, and ensuring the fundamental rights and freedoms of the people, For strengthening of political, social, economic, and defensive institutions of the country, For ensuring a prosperous life, and sound environment for all those residing in this land...

Id.

230. The constitution is instituted "In the name of God, the Merciful, the Compassionate." Id. ("We the people of Afghanistan: With firm faith in God Almighty and relying on His lawful mercy, and Believing in the Sacred religion of Islam,...").

231. Id. ch. 1, art. 2.

232. Id. ch. 10, art. 1.

233. But see Khaled M. Abou El Fadl et al., Democracy and Islam in the New ConstituTION OF AFGHANISTAN 2 (Cheryl Benard \& Nina Hachigian eds., 2003) ("While references to Islam are customary and appropriate, attention should be devoted to clauses that give some specificity to Islam's official status. Islam must be enshrined in a way that it is expressed through normal democratic mechanisms, rather than supplanting them.").

234. Constitution of A fghanistan ch. 1, art. 3.

235. In the United States' context, the toleration of obscenity and indecent speech is a useful analogy. See, e.g., Ashcroft v. ACLU, 535 U.S. 564 (2002); Miller v. California, 413 U.S. 15 (1973).

236. Constitution of Afghanistan ch. 1, art. 2.

237. See Larry Catá Backer, Constitution and Apostasy in Afghanistan, Law at the End of the Day, http://lcbackerblog.blogspot.com/2006/03/constitution-and-apostasy-in.html (Mar. 28, 2006, 21:46 EST). 
state a positive obligation to further the inculcation of Islam, Islamic religion and values, on the population through education. ${ }^{238}$ Islamic values also shape the state's responsibility to the family under the Afghani Constitution. ${ }^{239}$

The symbolic aspects of Afghani constitutionalism reinforces its theocratic and constitutionalist focus - the lawful institution of religion as the basic framework for political organization. All symbols of legitimacy are grounded not in popular sovereignty but in the suzerainty of Islam. This includes the flag, ${ }^{240}$ the national anthem, ${ }^{241}$ and the presidential oath of office. ${ }^{242}$ But legitimacy through Islam also shapes the extent to which internal political action is treated as legitimate. Thus, for example, the right to form political parties is guaranteed, ${ }^{243}$ as long as the "program and charter of the party are not contrary to the principles of sacred religion of Islam ...." 244 The preservation and legitimating function of these regulations of political life become clearer when these provisions are considered against the prohibition of factionalism within Islam in the form of political parties. Thus, while a religious political party might be formed, as long as it is Is-

238. See Constitution of A fghanistan ch. 2, art. 23 ("The state shall devise and implement a unified educational curriculum based on the provisions of the sacred religion of Islam, national culture, and in accordance with academic principles, and develops the curriculum of religious subjects on the basis of the Islamic sects existing in Afghanistan.").

239. See id. ch. 2, art. 32 ("The state adopts necessary measures to ensure ... upbringing of children and the elimination of traditions contrary to the principles of sacred religion of Islam.").

240 . Id. ch. 1 , art. 19 provides that " $[\mathrm{r}]$ he national insignia of the state of Afghanistan is composed of Mehrab and pulpit in white color.... In the upper-middle part of the insignia the sacred phrase of 'There is no God but Allah and Mohammad is his prophet, and Allah is Great' is placed, along with a rising sun."

241. Id. ch. 1, art. 20 provides that "[t] he National Anthem of Afghanistan shall be in Pashtu and mention 'Allahu Akbar' and the names of the ethnic groups of Afghanistan."

242. See id. ch. 3, art. 4 ("In the name Allah, the Merciful, the Compassionate In the name God Almighty, in the presence of you representatives of the nation of Afghanistan, I swear to obey and safeguard the provisions of the sacred religion of Islam, ..."). Scholars have noted the way that theocratic constitutionalism privileges members of a plural polity through the imposition of religious tests of a variety of sorts-including the use of oaths. "[T]he constitutions of a number of predominantly Muslim countries may restrict to Muslim citizens the right to serve in government positions, particularly to hold executive power. This is achieved by requiring a specific Islamic oath or by stipulating that only Muslims can hold a given position." Tad Stahnke \& Robert C. Blitt, The Religion-State Relationship and the Right to Freedom of Religion or Belief: A Comparative Textual Analysis of the Constitutions of Predominantly Muslim Countries, 36 Geo. J. INT'L L. 947, 974 (2005). The constitutional traditions of several Western states continue a similar practice-especially in Latin America. See, e.g., Constitution of Argentina part I, ch. 1, $\S 2$, available at http://pdba.georgetown.edu/Constitutions/Argentina/ argen94_e.html ("The Federal Government supports the Roman Catholic Apostolic religion.").

243. Constitution of Afghanistan ch. 2, art 14.

244. Id. 
lamic, no such party can be formed under the Afghani Constitution if it is based on an "Islamic School of thought."245

The Afghani Constitution also incorporates theocratic elements within its constitutionalist structure of the judiciary. The criteria for the selection of judges are meant to emphasize the Islamic character of the legal basis of the state. ${ }^{246}$ The Constitution enforces a rule of law regime on the judiciary, requiring judicial review to be in "compliance with the Constitution of laws, legislative decrees, international treaties, and international conventions, and interpret them, in accordance with the law," ${ }^{247}$ but in critical respects that review function is grounded in principles of Islamic law, which must be applied directly under certain circumstances, even the context of constitutional review. ${ }^{248}$ Islam thus serves as the meta-constitutional principles through which the constitution is interpreted and applied. ${ }^{249}$ In Afghanistan, then, there is the possibility of building an Islamic state that is also legitimately constitutionalist. That building serves to expose the despotically (and illegitimately) theocratic dispositions of the Taliban and also suggests some of the winners and losers within this constitutionalist matrix. Clearly, a system that is grounded in one religion will tend to treat others as both potential rivals and competitors. Though it may tolerate them, it will not treat them as equal members of

245. Id. ("Formation and functioning of a party based on ethnicity, language, Islamic school of thought (mazhab-i fiqhi) and region is not permissible.").

246. See id.ch. 7, art. 3 (specifying the qualifications of Afghani Supreme Court justices as requiring "a higher education in law or in Islamic jurisprudence"). Such judges "swear in the name of God Almighty to support justice and righteousness in accord with the provisions of the sacred religion of Islam and the provisions of this Constitution and other laws of Afghanistan." Id. ch. 7, art. 4.

247. Id. ch. 7, art. 6.

248. "When there is no provision in the Constitution or other laws regarding ruling on an issue, the courts' decisions shall be within the limits of this Constitution in accord with the Hanafi jurisprudence ..." Id. ch. 7, art. 15 . Special provision is made for the application of Shi'a law under certain circumstances. Id. ch. 7, art. 16. "Ultimately, whenever the norms of international law are taken to contradict Islamic principles, the Supreme Court may consider them unconstitutional. Such an approach reflects the view of Muslim scholars that there is no other source of law, whether domestic or international, than the divine will of God." Michael Schoiswohl, The New Afghanistan Constitution and International Law: A Love-Hate Affair, 4 INT'L J. ConsT. L. 664, 670 (2006).

249. But this Islamification is also highly contextualized within the history and culture of the peoples of Afghanistan. For an excellent analysis, see Christina Jones-Pauly \& Neamat Nojumi, Balancing Relations Between Society and State: Legal Steps Toward National Reconciliation and Reconstruction of Afghanistan, 52 AM. J. Comp. L. 825 (2004). See also Faiz A hmed, Afghanistan's Reconstruction, Five Years Later: Narratives of Progress, Marginalized Realities, and the Politics of Law in a Transitional Islamic Republic, 10 GoNz. J. INT'L L. 269, 299 (2007) (suggesting the difficulty of subconstitutional elaboration of the human rights protections described in the Afghani Constitution in light of the opposition of traditionalist Islamic law-grounded elites). 
the polity. All value systems are subordinated to the meta-norm, including those of religion, which must be assimilated in order to survive. ${ }^{250}$ But the result is neither theocracy nor despotism, but instead it is a constitutionalist project with its own internal logic, true to itself and grounded in theories of right and justice permitting accountability and limiting discretion.

\section{B. Theocratic Constitution Without Theocratic Constitutionalism-The Case of Saudi Arabia}

Saudi Arabia presents an example of a theocracy without theocratic constitutionalism.

The reform mission, upon which the saudi state was founded, represents the main core of the government. This mission is based on the realization of islamic rules, implementation of islamic law (shari'a), and enjoining good and forbidding evil, as well as to reform the islamic creed and purify it from heterodoxies. Therefore, it adopts its doctrine from the true islamic principles that were prevailing at the very beginning of islam. ${ }^{251}$

The Constitution of Saudi Arabia is the Qur'an. ${ }^{252}$ The foundational roles of Islam, ethnicity, and state are emphasized in the short section describing the rights and duties of the state. ${ }^{253}$ The state has an overriding obligation for the care and maintenance of the foundational religion on which its authority is based. ${ }^{254}$ The

250. As Justice Antonin Scalia noted in relation to the subordination inherent in nationalist constitutionalist systems, like that of the United States:

Just as a society that believes in the negative protection accorded to the press by the First Amendment is likely to enact laws that affirmatively foster the dissemination of the printed word, so also a society that believes in the negative protection accorded to religious belief can be expected to be solicitous of that value in its legislation as well. . . It may fairly be said that leaving accommodation to the political process will place at a relative disadvantage those religious practices that are not widely engaged in ....

Employment Division v. Smith, 494 U.S. 872, 890 (1990).

251. The Basic System of Governance (Saudi Arabia) pmbl., available at http://www.mofa.gov.sa/ Detail.asp? InNewsItemID $=35297$ [hereinafter Saudi Basic Law].

252. The Saudi "constitution is the holy qur'an and the prophet's (peace be upon him) sunnah (traditions)." Id. art. 1.

253. See id. arts. 23-43.

254. See, e.g., id. art. 23 ("The state shall protect the islamic creed and shall apply islamic shari'ah. The state shall enjoin good and forbid evil, and shall undertake the duties of the call to islam."); 
obligation extends beyond its borders - - suggesting the inferior position of state to ethnos and religious community. ${ }^{255}$ It extends to science and culture, bent to the religious will. 256

The document in which the Quranic state is constituted is called the Basic System of Governance, or the Basic Law. ${ }^{257}$ That document is administrative rather than constitutive in character-the divine having already constituted the state and decreed its organization in accordance with its superior and transcendent will. The Basic Law explicitly represents a subordinate articulation of the practices of government and its relation to both individuals and institutions. It is promulgated in the style of the old imperial constitutions of the German Reich ${ }^{258}$ and Japan, ${ }^{259}$ by right of the monarch on behalf of his people in the service of the greater system with respect to which he has been vested with governance power in a representative capacity. ${ }^{260}$

see also id. art. 24 (referencing protection and maintenance of holy sites and shrines).

255. See, e.g., id. art. 25 ("The state shall be keen to realize the aspirations of the arab and muslim nations with regard to solidarity and unity while enhancing its relations with friendly states.").

256. See id. art. 29 ("It shall encourage scientific research, shall preserve Arab and Islamic heritage and shall contribute to Arab, Islamic and human civilization"). There is a curious resonance here with developments in Catholic thinking about faith and reason. See His Holiness Pope John Paul II, Fides et Ratio (Sept. 14, 1998), available at http:/www.vatican.va/edocs/ENG0216/_INDEX.HTM (suggesting a resonance with recent efforts to clarify the relationship between education and Catholic beliefs within religious institutions of higher education); see also His Holiness Pope John Paul II, Apostolic Constitution of The Supreme Pontiff John Paul II On Catholic Universities (Ex Corde Ecclesiae) II 13 (Aug. 15, 1990), available at http://www.vatican.va/holy_father/john_paul_ii/apost_ constitutions/documents/hf_ip-ii_apc_15081990_ex-corde-ecclesiae_en.html ("Since the objective of a Catholic University is to assure in an institutional manner a Christian presence in the university world confronting the great problems of society and culture, every Catholic University, as Catholic, must have the following essential character istics: 1. a Christian inspiration not only of individuals but of the university community as such; 2 . a continuing reflection in the light of the Catholic faith upon the growing treasury of human knowledge, to which it seeks to contribute by its own research; 3 . fidelity to the Christian message as it comes to us through the Church; 4 . an institutional commitment to the service of the people of God and of the human family in their pilgrimage to the transcendent goal which gives meaning to life."); Larry Catá Backer, Fides et Ratio: Religion and Law in Legal Orders Suffused by Faith, Law at the End of the Day, http://lcbackerblog.blogspot.com/2007/07/ fides-et-ratio-religion-and-law-in.html (July 30, 2007, 15:52 EST).

257. Id.

258. See Constitution of the German Empire (1871), available at http://en.wikisource.org/wiki/ Constitution_of_the_German_Empire.

259. See Meinji Kenpō(Japan), available at http://history.hanover.edu/texts/1889 con.html. 260. Thus, the preamble of the Saudi Basic Law provides:

By the help of allah We, fahd bin abdul aziz, the king of the kingdom of saudi arabia, consistent with the public interest, and in view with the development of the state in different fields, in addition to our enthusiasm to achieve our pros- 
The Saudi state is constituted as "sovereign arab islamic state"261 for the preservation of which its citizens are required to conform their behavior or be punished. ${ }^{262}$ Its symbols of state and its holidays are institutionalizations or expressions of the supremacy of its faith community, ${ }^{263}$ as well as its national character as sovereign and Arab. ${ }^{264}$ The government is constituted as a monarchy for which the male children of the founder are eligible for kingship. ${ }^{265}$ However, there is a separation between government and power, with the implication that the king must serve underlaw - that is, the rules of the Quranic constitution. ${ }^{266}$ Indeed, the Basic Law explicitly states that " $[\mathrm{t}]$ he authority of the regime is derived from the holy Qur'an and the prophet's sunnah which rule over this and all other state laws"267 and that "[c]itizens shall pledge allegiance to the king on the basis of the holy qur'an and the

pected objectives, we ordered the following: First: issue the basic system of governance according to the context herein below.

Saudi Basic Law, pmbl.

261. Id. art. 1.

262. See id. art. 12 ("Fostering national unity is a must, and the state shall forbid all that may lead to disunity, sedition and division.").

263. Thus, for example, national holidays are essentially religious holidays. See id. art. 2 (stating "eid al-fitr (a religious feast celebrated on the lst of shawal, the 10th month of the islamic calendar), and eid al-ad-ha (a religious feast celebrated on the 10th of dhul-hijjah, the 12th month of the islamic calendar), and its calendar is the hijra (lunar)"). The nation's flag is a proclamation of faith. See id. art. 3 ("An article written in the middle of the flag translated as 'there is no god but allah, muhammad is allah's messenger' with a drawn sword underneath.").

264. See id. art. 4 ("The state's emblem consists of two intersecting swords with a date palm in the upper space between them. Both the national anthem and the badges of honor shall be determined by the law.").

265. Id. art. 5. For elaboration on the state apparatus, see id. arts. 44-71. The King is assisted by the Majlis Al-Shoura consultative assembly, though its powers are limited and its existence subject to the royal will. See id. art. 68 ("The King shall have the right to dissolve the Majlis Al-Shoura and re-form it"). In addition, the King is free to constitute such other persons and bodies as he wishes. See id. art. 69 ("The King may call the Council of Ministers and Majlis Al-Shoura to hold a joint meeting to which he may invite whomsoever he wishes for a discussion of whatsoever issues he may like to raise"). The object is conformity to the consultative (Shoura) system which was said to exist before the formation of the Kingdom. See id. In that context, the Basic Law requires that the "Majlis" of the King and the "Majlis" of the Crown Prince shall be open to all citizens and to anyone who may have a complaint or a grievance. Id. art. 43.

266. See id. art. 5(b) ("The most eligible among them shall be recognized as king, to rule in accordance with the holy qur'an and the prophet's sunnah."). The obligation extends to the state apparatus and the citizenry. See id. art. 33 ("The State shall build and equip the armed forces to defend the Islamic faith, the Two Holy Mosques, the society and the homeland."); see also id. art. 34 ("Defending the Islamic faith, the society and the homeland shall be the duty of each and every citizen. Rules of military service shall be spelled out by the law.").

267. Id. art. 7. 
prophet's sunnah." ${ }^{268}$ While the monarch may legislate in accordance with the system implemented through the Basic Law, ${ }^{269}$ Qu'ran and Shari'a occupy a superior place within the hierarchy of law. ${ }^{270}$ Shari'a is directly applicable both to the constitution of government and to the obligations of individuals. ${ }^{271}$

All relationships between the state and individuals are subordinated to the substantive and formal rules of religion. Legislation is essentially administrative in character. Law is finite, limited, and immutable-the divine legislature has delivered the eternal code-it remains for the Saudi monarchy to administer its patrimony in stewardship for a higher authority, to which all individuals might contribute in accordance with their role in the community. ${ }^{272}$ Furthermore, the monarch is given authority to implement judicial rulings and to issue decrees that could affect the method and rules by which courts base their decisions, so long as the decrees do not contradict the Koran or Sunnah. ${ }^{273}$ The monarch also "carries out the policy of the nation ... oversees the implementation of the Islamic Shariah, the system of government, the state's general policies... and the protection and defense of the country."274 In that context, the state recognizes a limitation on the power of the state as against individuals, but only to the extent such is permitted by higher law. "The state shall protect human rights in accordance with islamic shari'ah."275 In-

268. Id. art. 6.

269. The Basic Law recognizes the power of the monarchical apparatus to issue law. See, e.g., id. art. 3 (national holidays); art. 4 (the national flag), art. 15 (exploitation of natural resources), art. 20 (taxation), art. 35 (Saudi nationality), art. 38 (criminal law), art. 52 (appointment of judges), art. 59 (regulation of civil service), art. 74 (sale of state property). However, such law making remains subordinate to both Qur'an and Shari'ah. Id. art. 8 ("The system of governance in the kingdom of saudi arabia is based on justice, consultation 'shoura' and equality according to the islamic shari'ah (the law of islam).").

270. See id. arts. 7-8.

271. "The saudi society shall cling to the god's shari'ah." Id. art. 11.

272. There is an irony here-the conservative Islamist theocracy mimics, in last respect, the original and Jewish prototype-the Kingdom of Israel as constituted before the Roman expulsion in the first century of the common era. See Suzanne Last Stone, Religion and State: Models of Separation From Within Jewish Law, 6 INT'L J. CONST. L. 631, 635-39 (2008) ("We can quibble the use of the term theocracy, rather than "divine nomocracy" or even "sacred anarchy." Still, the impression left from reading the Hebrew Bible is that the religion is the political order. Thus, the biblical metaphors of intentional disobedience to that law revolve around treason and betrayal no less than sin." (d. at 635).

273. Saudi Basic Law arts. 48, 50.

274. Id. art. 55.

275. Id. art. 26. It is in that context that the foundational human rights protections offered through the Basic Law can be understood. See, e.g., id. art. 36 ("No individual shall be detained, imprisoned or have his actions restricted except under the provisions of the law."); see also id. art. 37 ("Houses are inviolable. They shall not be entered without the permission of their owners, nor shall they be 
deed, the Basic Law confirms the role of Saudi society as grounded in the obligation to live according to and to propagate Islam. ${ }^{276}$ "The goal of education is to instill the islamic creed." 277 That educational goal is shared by the Saudi media. ${ }^{278}$

There is thus religion aplenty in the constitution of the Saudi Arabian state, but very little constitutionalism. It is clear that the organization of the Saudi state and its religious foundation is inconsistent, in significant respects, from consensus notions of nationalist or transnational constitutionalism. ${ }^{279}$ But it is also clear that the Saudi organizational form does not conform to incipient notions of theocratic constitutionalism. It is, as one commentator recently suggested, a sort of ornamental constitutionalism; the Saudi Basic Law

is unabashedly honest, promulgating no rights that will not be protected, promising no elections, and not conceding the principle of accountable governance in any direct way. Indeed, the Saudi Basic Law signifies, if anything, a qualified rejection of many of the standard notions of constitutionalism in terms of rights and freedoms, while ratifying a powerful executive circumscribed only by historical practices and Islamic ideas of governance. ${ }^{280}$

searched except in cases specified by the law."); id. art. 38 ("No crime shall be established as such and no punishment shall be imposed except under a judicial or law provision."); id. art. 40 ("All forms of correspondence, whether conveyed by telegraph, post or any other means of communication shall be considered sacrosanct. They may not be confiscated, delayed or read, and telephones may not be tapped except as laid down in the law.").

276. Thus the Basic Law imposes on the Saudi family the obligation to conform to Islam, to cultivate nationalist feeling, and to obey state authorities. See id. art. 9 ("[M]embers shall be raised and adhere to the islamic creed which calls for obedience to god, his messenger and those of the nation who are charged with authority; for the respect and enforcement of law and order; and for love of the motherland and taking pride in its glorious history."). The state is charged with ensuring that Saudi families develop their ties to Islam and A rab ethnic identity. See id. art. 10 ("The state shall put great attention to strengthen the bonds which hold the family together and to preserve its arab and islamic values.").

277. Id. art. 13. In addition, such educated citizens have an obligation of utility "to impart them with knowledge and skills so that they become useful members in building their society, who love their homeland and be proud of its history." Id.

278. See id. art. 39 ("They shall play their part in educating the masses and boosting national unity.").

279. For an official analysis that is critical of the Saudi state, see, for example, U.S. DEP'T OF STATE, Saudi Arabia Country Reports on Human Rights Practices 2003 (2003), available at http:// www.state.gov/g/drl/rls/hrrpt/2003/27937.htm.

280. Abdulaziz H. Al-Fahad, Ornamental Constitutionalism: The Saudi Basic Law of Governance, 30 YALE J. INT'L L. 375, 376 (2005). 
There are no rule of law limits on the state-indeed there is no state, except in the relationships between Saudis and foreigners. ${ }^{281}$ Internally, the Saudi nation is constituted differently_-as a theocracy in which the executive branch, so to speak, is constituted as the monarchy, and the legislative and judicial branches are constituted as a blend of administrative officials and the traditional Islamic governance structures. ${ }^{282}$ Thus, it is clear that the constitution of the Saudi state is rich in substantive values, the fifth element of my working definition of constitutionalism. ${ }^{283}$ Such values are privileged over international norms and are used to interpret and implement those norms within the Kingdom. ${ }^{284}$ But much of the rest of the presumptions of constitutionalism are missing or weak, or an expression of a desire to obtain a measure of legitimacy within a more dominant foreign community of states. ${ }^{285} \mathrm{Or}$ they are a cloak to justify the institutionalization of family or clan power. ${ }^{286}$

281. See id. at 381 ("With respect to modern methods and structures of governance, and until the reforms of the 1990s, the pressures faced by the Saudi state derived from its external relations rather than from domestic demands.").

282. See id. at 378 ("Traditional norms of governance, which put a premium on consensus, prevailed throughout this time. Such norms were strongly influenced by the classical Islamic notions of rule, according to which, inter alia, the religiously trained scholars and jurists (the ulama) play a major role as grantors of legitimacy and act as a constraint against despotism.").

283. "To the disappointment of the many Saudi subjects who hoped for reforms that would impose real constraints on monarchical absolutism, the Basic Law turned out to offer Saudi subjects no means for holding their rulers accountable or for restraining monarchical discretion. That is, it was far from according with the principles of modern constitutionalism." Mayer, supra note 33, at 94.

284. See, e.g., Elizabeth Peiffer, The Death Penalty in Traditional Islamic Law and as Interpreted in Saudi Arabia and Nigeria, 11 WM. \& MARY J. WOMEN \& L. 507, 520 (2005).

285. This is nicely, though subtly, drawn out by Abdullahi Ahmed An-Na'im in Globalization and Jurisprudence: An Islamic Law Perspective, 54 EMORY L.J. 25, 48-49 (2005), who with a bit of perhaps unintended irony noted that,

By retaining this specific form of political and social organization after independence from colonial rule, Islamic societies have freely chosen to be bound by a minimum set of national and international obligations of membership in a world community of nation states. While there are clear differences in the level of their social development and political stability, all Islamic societies today live under national constitutional regimes-including countries that have no written constitution such as Saudi Arabia and the Gulf states-and legal systems that require respect for certain minimum rights of equality and nondiscrimination for all citizens. Even where national constitutions and legal systems fail to expressly acknowledge and effectively provide for these obligations, a minimum degree of practical compliance is ensured by the present realities of international relations.

Id.

286. See Mayer, supra note 33, at 84 (suggesting that Saudi and Moroccan "versions of Islamic constitutionalism do not flow from a common theory of Islamic government, but from strategies 


\section{Neither Here Nor There-Pakistan and Egypt}

Is it possible to have it both ways-to develop principles of theocratic constitutionalism while retaining an adherence to the normative structure of transnational constitutionalism, and especially those parts of transnational constitutionalism focused on human rights developed through and under the authority of non-religious bodies? We have seen how Afghanistan does not present a true picture of a form of constitutionalism straddling the religious and the secular for the basis of its legal and interpretive authority. Is it possible to blend a foundational basis for constitutional substance within the structures of a religion and still preserve the privilege of the normative values of the community of nations understood as constitutionalism; might Iraq, Pakistan, Egypt or Nigeria provide a better model?

Constitutionalism theories ought to suggest that the answer to these questions is no. ${ }^{287}$ Such a constitutional stance, like that of the antebellum United States, presents a state in a dynamic stage of its development. Even in a state grounded in rule of law process and values constitutionalism, a constitutional structure grounded in two or more inconsistent foundational values systems presents a contradiction that eventually requires resolution. In the United States a choice was made and equilibrium was reached through war. ${ }^{288}$ It is not clear how the dynamic state of constitutionalism-poised between the transnational and the theocratic-will resolve itself in these states.

\section{Pakistan}

of individual regimes for ratifying their hold on power").

287. But others suggest that the answer might be maybe. For a perceptive analysis in that direction, see Lama Abu-Odeh, The Politics of (Mis)recognition: Islamic Law Pedagogy in American Academia, 52 Ам. J. Comp. L. 789 (2004). The argument is that the "combination of presence (of Islamic law) and absence (of legal transplant) in the course materials assigned to by Islamic law instructors, the scholarship of law in the Islamic world by Islamic law scholars as well as by Comparativists, betrays an ideological project." Id. at 792. Instead, "Ig]iving Islamic law an overarching status analytically in our approach to law in the Islamic world, distorts our understanding of legal phenomena in these countries. Islamic law should be approached as one, but only one, of the constitutive elements of law that has not only been de-centered by the transplant but also transformed." Id. at 823 .

288. The American context was the contradiction of slavery in a federation grounded on values of freedom and human dignity as those ideas were understood at the time. Quoting scripture, Abraham Lincoln understood this even as he prepared for a martial resolution of the contradictions of American constitutional values. "'A house divided against itself cannot stand.' I believe this government cannot endure, permanently, half slave and half free. I do not expect the Union to be dissolved - I do not expect the house to fall - but I do expect it will cease to be divided." Abraham Lincoln, A House Divided (June 16, 1858) (quoting Matthew 12:25), available at http:// en.wikisource.org/wiki/A_house_divided. 
Pakistan is a state that has yet to find itself - at least from a constitutionalist perspective. As recent scholarship has suggested, reflecting a common understanding, Pakistan stands between constitutionalist rule structures, each of which has been naturalized within powerful national elites, which use and discard them to suit their objects of political supremacy. ${ }^{289}$ Its constitution has increasingly moved from a secularist internationalist orientation to one grounded in religion, a move that has pitted the execurive against the judiciary. ${ }^{290}$ Others see the move toward institutionalized Islam as a means of staving off something worse. ${ }^{291}$ But is it a theocratic constitutionalist project? This question requires a look at the document itself.

Pakistan is currently constituted as an Islamic Republic, in which Islam is the

289. See, e.g., Robert A. Scalapino, Introduction, in Asian Political Institutionalization 1, 15 (Robert A. Scalapino et al. eds., 1986) (noting that by the 1980s it had become clear that "in the judiciary system, three traditions compete: the British legal tradition, the autocratic military tradition, and the Islamic legal tradition. And the government, as in Bangladesh, betrays its concern over legitimacy by promising constitutionalism and the restoration of some form of parliamentarism."; also stating that "[i]n recent times, the Pakistan military led by Zia ul-Haq have sought legitimacy through a measure of Islamization, but this goal too is challenged, principally by the Westernized middle class").

290. This understanding was well put recently:

\begin{abstract}
What used to be the preamble to previous constitutions is now an operative part of the current Constitution as Article 2-A, and very much defines its ethos as a non-secular one. Yet, recent Pakistani judgments have put a halt to the discussion regarding whether Article 2-A can trump other constitutional provisions-thus acting as a sort of grundnorm-and have declared instead that it stands on an equal footing with other provisions of the Constitution, no more and no less. Indeed, these judgments have firmly precluded and strongly warned against an interpretation of Article 2-A which would raise it to the point of being a litmus test for gauging, evaluating, and potentially justifying the judiciary to strike down any other constitutional provisions.
\end{abstract}

Osama Siddique \& Zahra Hayat, Unholy Speech and Holy Laws: Blasphemy Laws in PakistanControversial Origins, Design Defects, and Free Speech Implications, 17 MINN. J. INT'L L. 303, 368 (2008) ("While acknowledging that various such provisions may be inconsistent with Article 2-A, the courts clearly warned that such an interpretive approach would undermine the entire Constitution"). Id.; see also Kamal Azfar, Constitutional Dilemmas in Pakistan, in PAKISTAN UNDER THE Military: Eleven Years of Zia Ul-HaQ 49-86 (Shahid Javed Burki et al. eds., 1991). For information on Islamification, see id. at 78-79.

291. See, e.g., Azfar, supra note 290, at 78 ("By imposing Islamic laws from above, Zia may have saved Pakistan from a fundamentalist revolution from below like the one that took place early in his tenure in neighboring Iran.... Internally Zia's most lasting contribution could be resolving the issue of the role of Islam in the state. Nonetheless, the question is not dead; several of the parties supporting Prime Minister Nawaz Sharif wish to enact legislation incorporating the key elements of Zia's Shariat Ordinance."). 
state religion. ${ }^{292}$ Within that context, the former preamble to the Constitution, ${ }^{293}$ modified in one critical respect, ${ }^{294}$ and inserted in an appendix, is made a part of the Constitution. ${ }^{295}$ Among the provisions of this former preamble are a number that touch on the religious constitution of the state, as well as its adherence to fundamental rights obligations not necessarily tied to religion. ${ }^{296}$ The Constitution also lists a number of policy principles made applicable to all state organs. ${ }^{297}$ While most guarantee fundamental process and substance rights, they do so without reference to religion. ${ }^{298}$ Islam, to the extent it is incorporated, is limited in its application to Muslims. ${ }^{299}$ The state, thus, appears empowered to legislate specifically for Muslims, but in a way

292. Constitution of Pakistan art. 2, available at http://www.pakistani.org/pakistan/constitution/ partl.html [hereafter Pakistan Constitution]. The term "Muslim" is also defined for purposes of the constitution. See id. art. 260(3) (a) "Muslim" means a person who believes in the unity and oneness of Almighty Allah, in the absolute and unqualified finality of the Prophethood of Muhammad (peace be upon him), the last of the prophets, and does not believe in, or recognize as a prophet or religious reformer, any person who claimed or claims to be a prophet, in any sense of the word or of any description whatsoever, after Muhammad (peace be upon him)."). Ironically, the definition of non-Muslim is notable for its selective omission of Jews. See id. art. 260(3) (b). Lastly, though there is no explicit prohibition of non-Muslims attaining high office, the constitutionally prescribed oaths of office do not contemplate non-Muslim office holders. See id. arts. 42, 91(4), 92(2), 53(2), 61, 65, 102, 131(4), 132(2), 127, 168(2), 178, 194, 203(c) (7), 214, 244.

293. Id. pmbl.

294. See id. art. 2(A), app. (stating the obligation to make "adequate provision ... for the minorities to profess and practice their religions and develop their cultures," was modified to eliminate the word "freely" from before the word "profess" so that the obligation is no longer to ensure that minorities can freely profess; that obligation is now reduced to mere profession).

295. Id.

296. See id. (including the following: the full observation of "the principles of democracy, freedom, equality, tolerance and social justice as enunciated by Islam;" the obligation to enable Muslims "to order their lives in the individual and collective spheres in accordance with the teachings and requirements of Islam as set out in the Holy Quran and the Sunnah;" the protection of "fundamental rights including equality of status, of opportunity and before law, social, economic and political justice, and freedom of thought, expression, belief, faith, worship and association, subject to law and public morality;" safeguarding the "legitimate interests of minorities and backward and depressed classes;" and securing the independence of the judiciary).

297. Id. arts. 29-40.

298. See, e.g., id. art. 33 (elimination of prejudice); art. 34 (empowerment of women); art. 35 (protection of family); art. 36 (protection of "legitimate rights" of minorities); art. 37 (promotion of social justice); art. 38 (promotion of social and economic well being).

299. Id. art. 31 ("(1) Steps shall be taken to enable the Muslims of Pakistan, individually and collectively, to order their lives in accordance with the fundamental principles and basic concepts of Islam and to provide facilities whereby they may be enabled to understand the meaning of life according to the Holy Quran and Sunnah. (2) The state shall endeavor, as respects the Muslims of Pakistan: (a) to make the teaching of the Holy Quran and Islamiat compulsory, to encourage and facilitate the learning of arabic language and to secure correct and exact printing and publishing 
that cannot infringe on the rights of minorities. ${ }^{300}$ It appears susceptible to other constraints as well, including Article 2(A) and the Principles. In addition, the solidarity clause supports both secular and political aims. ${ }^{301}$ But this balance appears to be upset by the Islamicizing provisions of Part IX, the Islamic Provisions. ${ }^{302}$ The relationship of minority faith communities to Islam is thus based on a toleration of practice within an overall pattern of subordination and conformity to the religio-political normative system of Islam—an assimilation of other faiths into the weltanschauung of Islam and their reconstruction of "soft Christianity" and others. ${ }^{303}$

In other respects, though, the government, as constituted, presents the usual picture of conventional separation of powers, with a president, ${ }^{304}$ a legislature, ${ }^{305}$ and a judiciary. ${ }^{306}$ The superior courts have jurisdiction to hear claims of violations of the rights of individuals. ${ }^{307}$ But, again, the vectors of constitutionalism turn in on themselves. In addition to the secular courts, the Constitution directs

of the Holy Quran; (b) to promote unity and the observance of the Islamic moral standards; and (c) to secure the proper organisation of Zakat, (usher) auqa and mosques.").

300. See id. art. $203 \mathrm{C}$ (2) (illustrating this point within the black letter of the Constitution itself through, for example, the creation of a Federal Shariat Court, whose membership is limited to Muslims).

301. Id. art. 40 ("The State shall endeavour to preserve and strengthen fraternal relations among Muslim countries based on Islamic unity, support the common interests of the peoples of Asia, Africa and Latin America, promote international peace and security, foster goodwill and friendly relations among all nations and encourage the settlement of international disputes by peaceful means.").

302. Id. arts. 227-31. The basic provision is set forth at id. art. 227(1) ("All existing laws shall be brought in conformity with the Injunctions of Islam as laid down in the Holy Quran and Sunnah, in this Part referred to as the Injunctions of Islam, and no law shall be enacted which is repugnant to such Injunctions."). An Islamic Council is established to implement the provisions of Article 227 of the Pakistan Constitution, as well as to advise Parliament with respect to Islamization. See id. arts. 228-30; see also id. art. 231 (noting this is to be done in accordance with rules to be established by the Council and approved by the President); id. art. 227(3) (providing an exemption for non-Muslims citizens).

303. Compare to the treatment of minority faiths in Iran, A fghanistan and Iraq, and contrast to the treatment of the same in Saudi theocracy. In a sense, these systems formalize the project of cooptation of a threatening system being attempted in an informal way by conventional constitutionalism. See, e.g., Catá Backer, Of Political States, supra note 166.

304. Pakistan Constitution arts. 41-49.

305. Id. arts. 50-89; see also id. arts. 62(d)-(e) (stating membership in Parliament is limited to Muslims in good standing, though this provision is suspended for non-Muslims, who need only demonstrate a "good moral reputation").

306. Id. pt. VII, chs. 1-4.

307. See id. arts. 184(3) ("[T]he Supreme Court shall, if it considers that a question of public importance with reference to the enforcement of any of the Fundamental Rights conferred by Chapter I of Part II is involved have the power to make an order of the nature mentioned in the said Article."); see also id. art. 199(c) ("Subject to the Constitution, the right to move a High Court for the enforcement of any of the Fundamental Rights conferred by Chapter I of Part II shall not be abridged."). 
the creation of a Federal Shariat Court. ${ }^{308}$ The jurisdiction of the Federal Shariat Court appears to upend the secular focus of the judicial structure of the state. ${ }^{309}$ Where the Shariat Court determines that a law or provision is repugnant to Islam, "such law or provision shall, to the extent to which it is held to be so repugnant, cease to have effect on the day on which the decision of the Court takes effect." 310 Decisions of the Federal Shariat Court are binding on all courts save the Federal Supreme Court. ${ }^{311}$ With respect to such cases, the appellate jurisdiction of the Supreme Court is limited, and its constitution is reordered-stripping all non-Muslims from any participation rights in those decisions. ${ }^{312}$ Literally construed, these provisions could effectively strip the Federal Supreme Court of its jurisdiction and create a hierarchy of constitutional values in which Islam trumps all, in a way preserved by a guardianship of Muslim members of the polity. But there is sufficient ambiguity to make this issue subject to interpretation. ${ }^{313}$

Taken together, the provisions of the Pakistan Constitution suggest an integrated, legitimate theocratic constitutionalist system. The Constitution limits the power of the state. Arbitrary actions by individuals holding state power governmental are avoided. Rule of law provisions apply both to the protection of the rights of individuals and the exercise of power by the state. There is a scrupulous attention to separation of powers and the suggestion of popular participation (though the deficiencies of Pakistani democracy are well known). But the protection of substantive rights - the normative limits on constitutional power appear founded on Islam. Both the courts and the legislature are made subject to the structures of Islam and the institutions of the state are bent to be those of an Islamist state. Of course, the consequences, in terms of human rights and the rights of

308. Id. pt. VII, ch. 3A.

309. See id. art. 203(D) (1) (noting the Constitution vests the Shariat Court with a broad jurisdiction). "The Court may, (either of its own motion or) on the petition of a citizen of Pakistan or the Federal Government or a Provincial Government, examine and decide the question whether or not any law or provision of law is repugnant to the injunctions of Islam, as laid down in the Holy Quran and Sunnah of the Holy Prophet, hereinafter referred to as the Injunctions of Islam." Id.

310. Id. art. $203 \mathrm{D}$ (3) (b). In addition, "(a) the President in the case of a law with respect to a matter in the Federal Legislative List or the Concurrent Legislative List, or the Governor in the case of a law with respect to a matter not enumerated in either of those Lists, shall take steps to amend the law so as to bring such law or provision into conformity with the Injunctions of Islam." Id. art. 203D(3) (a). 311. Id. art. 203GG.

312. Id. art. 203F.

313. Recall that Articles 184(3) and 199(c) of the Pakistan Constitution confer broad jurisdiction on the secular courts to hear complaints of violation of fundamental rights. How one reads the hierarchy of rights (Part I versus Part IX) and hierarchy of jurisdiction (Shariat system versus secular system) is not clear. See id. pts. I, IX. 
non-Muslim citizens of Pakistan will be different under this regime than under one grounded in the conventional normative structure of secular transnational constitutionalism. But even so, for the full members of the polity (Pakistani Muslims), a deep rule of law regime has been established.

But in the case of Pakistan, one may well have a case of sham or partial theocratic constitutionalism. Fully evolved on paper, its reality is clouded by the great struggles among those who have not acceded to the power or principle of the constriction of the state on these theocratic grounds. As applied, Pakistan suggests a polity at war with itself over the meaning and application of its constitutional settlement. Just as the foundation of the federal republic became a critical source of contention among the elites of the antebellum United States, Pakistani elites are currently struggling for control of the character of Pakistani constitutionalism as grounded in secular or religious principles. The institutional center of that struggle is the judiciary. ${ }^{314}$ For the moment, the Pakistani secular courts have interpreted narrowly the jurisdiction of the Shariat courts, asserted their power as final arbiter of constitutional interpretation, and narrowed the meaning of unIslamic. $^{315}$

\section{Egypt}

Egypt presents a variation on the Pakistani situation. Contemporary Western scholars have noted the difficulties of Egyptian governance.

The Egyptian experience has witnessed radical, violent revolutionary Islamic activism and the institutionalization of Islam socially and politically; diverse state policies toward Islam in the struggle of gover-

314. See Jeffrey A. Redding, Constitutionalizing Islam: Theory and Pakistan, 44 VA. J. INT'L L. 759, 764-65 (2004); see also Tina R. Karkera, Current Event: The Gang-Rape of Mukhtar Mai and Pakistan's Opportunity to Regain Its Lost Honor, 14 Am. U.J. Gender Soc. Pol'y \& L. 163, 169 (2006) (referencing a notorious case involving the rape of a woman: "Fearing a continued struggle between the competing jurisdictions of the High Court and the Shariat Court, the Supreme Court of Pakistan took over the case, ordering all files in the case to be sent to the Supreme Court."

315. Redding, supra note 314, at 773-807; see also Ali Adnan Ibrahim, The Rise of Customary Businesses in International Financial Markets: An Introduction to Islamic Finance and the Challenges of International Integration, 23 Ам. U. INT'L L. Rev. 661, 695 (2008) (quoting United Bank Ltd. v. M/S Farooq Bros., P.L.D. 2002 S.C. 800 (Pak.), P 18, June 24, 2002, available at http://www.supremecourt. gov.pk//sub_links/judgements/JUDGMENT\%20IN\%20RIBA\%20CASE.zip) (noting the Pakistani Supreme Court remanded a decision of the Shariat Court outlawing interest (riba) in all forms on the grounds that "in order for the Federal Shariat Court to conduct "thorough and elaborate research ... of financial systems ... prevalent in the contemporary Muslim countries."). 
ment and ruling elites to maintain their legitimacy and their world, with its lifestyle, power, and privileges; the growing polarization (as in many Muslim societies) between Islamists and secularists and government officials; advocacy of, and then reneging on, the government's official commitment to democratization, justified by the charge that "fundamentalists" are out to "hijack" democracy; and, finally, the widening of a confrontation between state security forces and Muslim extremists to include moderate as well as violent revolutionaries. ${ }^{316}$

The Constitution identifies the State as being an Arab Republic with Islam as its official religion. ${ }^{317}$ Egypt is a rule of law state in which the "[s]overeignty of the law shall be the basis of rule in the State." ${ }^{18}$ To the end of constructing a rule of law state, process constitutionalism is established. The Constitution institutes a government marked by a separation of powers, ${ }^{319}$ though one tilted in favor of executive authority, ${ }^{320}$ and a limitation of government action except in accordance with legally legitimate procedure. Moreover, constitutional amendment, though a power ultimately vested in the people, ${ }^{321}$ is to some extent also controlled by a distinct body, the Shura Council. ${ }^{322}$ That institutionalization of formal procedural protections extends

316. EsPosito \& VOLL, supra note 196, at 173.

317. Constitution of the Arab Republic of Egypt pt. 1, arts. 1, 2, available at http://constitution sis.gov.eg/en/2.htm [hereinafter Egyptian Constitution].

318. Id. art. 64. That sovereignty has two aspects—the "state is subject to law" and the "independence and immunity of the judiciary are two basic guarantees to safeguard rights and freedoms." Id. art. 65. For that purpose, the "State shall guarantee accessibility of judicature for litigants, and rapid decision on cases. Any provision in the law stipulating immunity of any act or administrative decision from the control of the judicature is prohibited." Id. at art. 68; see also id. art. 166 ("Judges shall be independent, subject to no other authority but the law.").

319. The constitution recognizes a traditional separation of powers of a parliamentary republic among an executive consisting of the President of the Republic (id. arts. 73-85, 137-52) and the "government" (id. arts. 153-63); the legislature (id. arts. 86-136), a judiciary (id. arts. 164-73) and a constitutional court (id. arts. 174-78).

320. See, e.g. id. art. 144 (power to issue regulations), art. 147 (power to issue decrees with force of law), art. 152 (power to call for popular referenda). As one analyst concluded, "the Egyptian legislature has little power relative to the executive. Egyptian law gives the executive power over the legislature in many areas." David S. SoREnson, AN INTROduction to the MOdern MiddLE EAST 242 (2008).

321. See Egyptian Constitution art. 189 (amendment proposed by Presdent or National Assembly and then subject to approval by popular vote).

322. See id. arts. 194-205. The Shura Council has similar powers with respect to treaties (id., art. 194(3)), and must be consulted with respect to a number of legislative matters. Id. art. 195. The Shura Council is to some extent a direct proxy for the people, including its lowest socio-economic classes, and to some extent a reflection of the privileged power position of the President. "Two thirds of the members shall be elected by direct secret public balloting, half of whom at least must be workers and farmers. The President of the Republic shall appoint the other third." Id. art. 196. 
to both actions of the state and its institutions, and actions against individuals. ${ }^{323}$ For all that, there are some problematic provisions under principles of transnational constitutionalism-among them the so-called anti-terrorism provisions of the Constitution $^{324}$ and the authority of the President over the police..$^{325}$

Substantive constitutionalism is also privileged within the formal structure of the Egyptian Constitution. The language is that of modern transnational constitutionalism. The family is protected. ${ }^{326}$ It is true that religion is privileged as a general matter within the constitutional framework. For example, religious instruction is imposed as a state and family obligation. ${ }^{327}$ However, the constitution itself does not privilege a single religion in that context. This contrasts with the Iranian and Saudi Constitutions, both of which privilege Islam in the black letter of the constitution itself. And, indeed, according to one Western analyst, the purpose seems to be to

323. Thus, for example, with respect to criminal actions against individuals, there "shall be no crime or penalty except by virtue of the law" and penalties "shall be inflicted only for acts committed subsequent to the promulgation of the law prescribing it" (id. art. 66), "right to litigation is inalienable and guaranteed for all, and every citizen has the right to have access to his natural judge" (id. art. 68), criminal actions shall not "be made except under an order from a judiciary body, save for cases defined by the law" (id. art. 70), and "should be informed forthwith of the reasons for his arrest or detention. ... have the right to communicate, with whoever he deems fit to inform, and ask for his help in the manner regulated by the law.... [and] shall be promptly faced with the charges levelled against him. Any person may lodge an appeal to the courts against any measure taken to restrict his individual freedom." $I d$. art. 71 .

324. See id. art. 174 ("The State shall seek to safeguard public security to counter dangers of terror. The law shall, under the supervision of the judiciary, regulate special provisions related to evidence and investigation procedures required to counter those dangers. The procedure stipulated in paragraph 1 of Articles 41 and 44 and paragraph 2 of Article 45 of the Constitution shall in no way preclude such counter-terror action."). These provisions constitutionalize emergency legislation in place for some time. They remain controversial. See, e.g., Divisive Egypt Reforms Approved, BBC NEws OnLINE, Mar. 27, 2007, available at http://news.bbc.co.uk/2/hi/middle_east/6498573.stm. ("The President may refer any terror crime to any judiciary body stipulated in the Constitution or the law.").

325. See id. art. 184 ("Police Authority shall be a statutory civil body. Its Supreme Chief shall be the President of the Republic. The Police Authority shall perform its duty in service of the people, maintain peace and security for citizens, maintain order, public security and morality, and undertake the implementation of the duties imposed upon it by laws and regulations, in the manner prescribed by the law."). It might be possible to see in these provisions a privileging of process over substantive protections by vesting the President with large police powers that might be exercised as long as all legal formalities are observed, especially when the police powers are read together with the anti terror provisions of the constitutions. See id. art. 174.

326. Id. art. 9 ("The family is the basis of the society and is founded on religion, morality and patriotism. The State is keen to preserve the genuine character of the Egyptian family-together with the values and traditions it embodies-while affirming and developing this character in the relations within the Egyptian society.").

327. See id. art. 9. In addition, article 19 provides that "Religious education shall be a principal topic of general education curricula." Id. art. 19. 
privilege nationalism over religion in the hierarchy of values that are captured and directed by the state. ${ }^{328}$ The Constitution recognizes the equality of all citizens under the law. ${ }^{329}$ The economic structure of the state is organized as a socialist democracy whose means of production are owned by the people. ${ }^{330}$ The constitution also recognizes a values-based limitation on the power of the state with respect to the individual. For example, the constitution covers rights and protections from illegal searches and seizures, ${ }^{331}$ freedom of religious belief, ${ }^{332}$ freedom of the press, ${ }^{333}$ and freedom of assembly. ${ }^{334}$ Last, the constitution forbids political parties formed on the basis of religion. ${ }^{335}$

But though the language of the constitution appears to embrace the core of the substantive values framework transnational constitutionalism, there are a number of provisions that suggest an alternative framework of substantive constitutionalism. First, the constitution points to a nationalist values basis for law: "Society shall be committed to safeguarding and protecting morals, promoting genuine Egyptian traditions. It shall give due consideration, within the limits of law, to high standards of religious education, moral and national values, historical heritage of the people, scientific facts and public morality." ${ }^{336}$ And the constitution imposes a positive obligation on the state to abide by and promote these principles. ${ }^{337}$ Second, one religion is privileged among others: "Islam is the religion of

328. See Johanna Pink, Religion and Democracy: An Exchange of Experiences Between East and West (Center for Religious Studies and Research Conference, 2003), available at http://www.cesnur .org/2003/vil2003_pink.htm.

329. Id. art. 40.

330. Id. arts. $4,24$.

331. Id. art. 44.

332. Id. art. 40 ("They have equal public rights and duties without discrimination on grounds of race, ethnic origin, language, religion or creed."); art. 46 ("The State shall guarantee the freedom of belief and the freedom of practice of religious rites.").

333. Id. art. 48. The Constitution describers the press as "a popular, independent authority exercising its mission in accordance with the stipulations of the Constitution and the law." Id. art. 206. But the press is also limited in the manner of its expression and the scope of its actions. It is required to behave in accordance with a constitutionally mandated mission: "It shall thus express trends of public opinion, while contributing to its formation and orientation within the framework of the basic components of society, the safeguard of the liberties, rights and public duties and respect of the sanctity of the private lives of citizens, as stipulated in the Constitution and defined by law." Id. art. 207.

334. Id. art. 54.

335. See id. art. 5 ("Citizens have the right to establish political parties according to the law and no political activity shall be exercised nor political parties established on a religious referential authority, on a religious basis or on discrimination on grounds of gender or origin.").

336. Id. art. 12.

337. Id. 
the state and Arabic its official language. Principles of Islamic law (Sharia) are the principal source of legislation." ${ }^{338}$ That constitutional privileging appears to incorporate the legal structures of Islam into the substantive and procedural framework of Egyptian constitutionalism. But the language is ambiguous. It is not clear, for example, what "principal source" means. The ambiguity extends to the judicial role in the incorporation of Islamist values. On the one hand, the secularization of the judicial function suggests a move away from theocratic values. ${ }^{339}$ On the other hand, that secularization placed control of religious matters of the minority community in the hands of a secular court system subject to the overarching obligation to adopt a greater sensitivity to Sharia in its decisions. ${ }^{340}$ Yet, there is a sense of the centrality of Islam in at least area of constitutional limitation on state legislative power-the rights of women. ${ }^{341}$ And there is an indication of a hierarchy of religious tolerance, whose limits have recently been tested. ${ }^{342}$

Egypt represents that peculiar case of the state that occupies a space between the secular and the religious forms of transnational constitutionalism. It is a compromise state, a state that seeks a reconciliation of the irreconcilable. That makes for a certain level of volatility. It is a state at war with itself over its understanding of its fundamental character. What some see as the ability of one segment of the state ap-

338. Id. art. 2.

339. Egypt was among a group of Muslim majority states that abolished its religious courts-Islamic, Christian and Jewish-and folded their jurisdiction into the secular court system. SORENSON, supra note 320, at 242.

340. Egyptian Constitution art. 2. "There is also evidence that judges are increasingly relying on Sharia as a legal basis for their decisions." SORENSON, supra note 320 , at 242 . Thus, in effect, the judiciary has been secularized as a formal matter, but to assert control the judiciary then deploys the religious laws over which it has sought a measure of control. The state apparatus becomes theocratic, but rather than under the guidance of imams, it internalizes the power of religious interpretation ads a matter of public and constitutional law.

341. See Egyptian Constitution art. 11 ("The State shall guarantee harmonization between the duties of woman towards the family and her work in the society, ensuring her equality status with man in fields of political, social, cultural and economic life without violation of the rules of Islamic jurisprudence.").

342. Thus, for example, the Egyptian government had traditionally limited recognition to three religions-Islam, Christianity and Judaism-forcing adherents of other religions to greater difficulties in vindicating even the right to obtain identity papers. See, e.g., Human Rights Watch, Egypt: Court Prohibits Withholding Documents from Baha' is, Jan. 29, 2008, available at http://www. hrw.org/en/news/2008/01/29/egypt-court-prohibits-withholding-documents-baha ("The Cairo Court of Administrative Justice granted the request of Baha'i Egyptians to obtain birth certificates and identity cards without indicating any religious affiliation. The decision overturned the government's policy of forcing Baha'i Egyptians to choose one of the three state-recognized religions of Islam, Christianity and Judaism as a prerequisite for obtaining identification documents."). 
paratus (the courts) to slow the move toward a particular view of the black letter of its constitution, ${ }^{343}$ others might see as evidence of future civil strife-much like that which boiled over in the United States in $1861 .^{344}$ Egyptian constitutionalism represents an attempt to secularize Islam or to engineer an Islamist values constitutionalism in which the state is both bound by, but directs, the religious establishment to which it is subject. In that sense, Egyptian constitutionalism offers an inversion of the Iranian model and a variation from the Afghani model. ${ }^{345}$ The Egyptian Supreme Court's assertion of authority to declare the meaning of Shari'a and its willingness to mold that interpretive authority flexibly appears to permit a blending of secularist and religious universalism by providing a point from which convergence of substantive results is possible, even if the process to get to this result is different. ${ }^{346}$ "In fact, the Court established its own interpretation of ijtihad irrespective of the

343. See, e.g., Hirschl, supra note 165, at 1822 (on the efforts of the Egyptian Supreme Court to recast Egyptian constitutionalism through the construction of a constitutionalist jurisprudence).

344. One can argue that, like the Egyptian Supreme Court today, the U.S. Supreme Court in the early Republic also took a principled, interpretive stance, but one that was hardly reflective of a political consensus on the nature of the federation and the power of the general government of the union. It took a civil war and substantial constitutional revision for such a position to ultimately be vindicated. See Larry Catá Backer, The Extra-National State: American Confederate Federalism and the European Union, 7 Colum. J. Eur. L. 173, 179-93 (2001).

345. As one commentator noted: "In Saudi Arabia and Iran, supreme religious councils dictate how Islamic law is applied and, to a large extent, have veto power over legislation. In mixed religioussecular systems, such as in Egypt, sharia personal law courts are integrated into a Western-based legal system, and a secular supreme court has the final say," Sharon Otterman, Islam: Governing Under Sharia, Council on ForeIGN Rel., Mar. 14, 2005, available at http://www.cfr.org/publication/8034/ (referencing statements of Nathan Brown of the Carnegie Endowment for International Peace).

346. Thus, for example, Ran Hirschl noted that in its role as arbiter of Shari'a compliance, the Egyptian Supreme Constitutional Court, like its Pakistani counterpart,

has departed from the ancient traditions of the fiqh (Islamic jurisprudence or the cumulative knowledge and science of studying the Shari'a) schools and has developed a new framework for interpreting the Shari'a. Specifically, the Court has developed a flexible, modernist approach to interpreting the Shari'a that distinguishes between "unalterable and universally binding principles, and malleable application of those principles."

Hirschl, supra note 165, at 1824; see also Clark B. Lombardi \& Nathan J. Brown, Do Constitutions Requiring Adherence to Sharia Threaten Human Rights?, 21 AM. U. INT'L L. REv. 379 (2006) (using the example of Egypt's judicial engagement with Sharia to suggest the possibility of an Islamist jurisprudence that can produce results similar to those expected under a secular transnational constitutionalist legal regime). Yet that balancing appears to favor Islam over other minority positions. See, e.g., Islamic Judges Strip Christian Mothers of Children Muslim Fathers, Courts Fear Youth May Switch Religions, Eat Banned Foods, 'Go to Church', WORLDNET DAILY, Nov. 21, 2008, available at http://www.worldn etdaily.com/index.php? fa = PAGE.view\&pageId = 81963 ("Egyptian human rights workers are seeking 
contradictory opinions in Islamic jurisprudence, the fiqh, and its traditional methods. The SCC [Egyptian Supreme Constitutional Court] thereby positioned itself as a de facto interpreter of religious norms." ${ }^{\text {347 }}$ But it may not make for a model of either theocratic constitutionalism or its secular nationalist or transnationalist counterparts. This is a state that fails in both respects.

Yet this failure may be necessary for the survival of the Egyptian state apparatus as currently constituted. As a transnational constitutionalist state, the construction of the state apparatus suffers some potentially severe de-legitimating featuresincluding the weakness of separation of powers, the anti-terrorism powers of the police and courts, the internal authority of the military, and restrictions on the powers of the press. Moreover, its privileging of Islam is also problematic. On the other hand, as a theocratic constitutionalist state it also fails because it has not ceded authority to the religious establishment in matters of Sharia interpretation. That function remains with the state courts, most of whose judges are unlikely to be recognized as legitimated invested Islamic scholars or jurists. Nor is there a requirement for such qualification in the Constitution. It might well be that the dynamism of straddling transnational and theocratic constitutionalism serves the state well for the moment-allowing it to retain for itself substantial power while taking advantage of the popular notions of incorporating religious law principles in secular law. It thus asserts theocratic constitutionalism as a defense against its transnationalist constitutionalist critics and asserts transnational constitutionalist principles against theocratic and theocratic constitutionalist critics; a delicate balancing act indeed! $!^{348}$

\section{Constitutions With Theocratic Elements: Malaysia and Sri Lanka}

Is it possible to enshrine religion within a constitutional framework and not further theocratic constitutionalist aims? The project of categorizing constitu-

support from the international community to stop Muslim judges from using Shariah law to undermine custody rights of Christian mothers.").

347. Hirschl, supra note 165 , at 1827.

348. As one commentator noted in assessing the failure of American style civil society-based litigation related challenges to the Egyptian regime. "The ultimate collapse of the human rights movement, the continued weakness of opposition parties ... demonstrate how litigation alone, without support from broad sectors of society, was insufficient to protect the SCC [Supreme Constitutional Court]-civil society coalition from collapse." Tamir Mustafa, Got Rights? Public Interest Litigation and the Egyptian Human Rights Movement, in Human Rights in the ARAB WorLd 152, 173 (Anthony Chase \& Amr Hamzawy eds., 2006). For another perspective of this balancing between two values systems, see Neil Hicks, Transnational Human Rights Networks and Human Rights in Egypt, in Human Rights IN THE ARAB WORLD, supra, 64-88. 
tions is harder than it might appear at first blush. This project poses difficult questions of interpretation, especially with respect to constitutions that seem poised between the two systems. For purposes of this article, I look to two examples, the first Islamic and the second Buddhist.

\section{Malaysia}

Malaysia provides an example of a conflation of religion and ethnicity similar to that of Saudi Arabia, but implemented within a vastly different context for a different purpose. Where the Saudis meant to constitutionalize the Muslim and Arab character of the state, the Malays sought to construct that singular character in a context in which native Malays feared being reduced to minority status in the lands that would become Malaysia. ${ }^{349}$ The ascendancy of the Malays was expressed in the construction of the state: "Malay replaced English as the language of administration and education (except at the primary level where Chinese and Tamil continued to be used). Malay culture was given increased prominence in official ceremonies and television programs, and Islam became more fully identified with the state." ${ }^{350}$ Malaysia represents a community that has conflated religion with ethnicity in the construction of what its proponents suggest is a legitimate basis of ethno-religious chauvinism. ${ }^{351}$ In an interesting twist, at least one of its defenders suggests that ethno-religious chauvinism can be supported as a principled rejection of conventional constitutionalist notions of equal treatment because, in plural societies, even conventional constitutionalists differ on the effectiveness of a color-blind approach to constitutionalism. ${ }^{352}$ The effect is that rec-

349. H.P. Lee, Competing Conceptions of Rule of Law in Malaysia, in AsIAN Discourses of RuLE of Law: Theories and Implementation of Rule of Law in Twelve Asian Countries, France AND THE U.S. 225, 233 (Randall Peerenboom ed., 2004) ("The state of constitutionalism in Malaysia is influenced by a number of factors. The rejection by the largest racial group, the Malays, of the Malayan Union was the result of a feeling of insecurity arising from the proposed creation of a common citizenship.... The fear was that Malay power would be diluted by a swelling in the number of citizens of other races, particularly the Chinese and Indians.").

350. Harold Crouch, Government and Society in Malaysia 239 (1996).

351. See C.L. Lim, Race, Multi-Cultural Accommodation and the Constitutions of Singapore and Malaysia, 2004 Sing. J. Legal Stud. 117, 117 (suggesting "a difference between constitutional and unconstitutional forms of ethno-racial essentialism"). Lim writes, "It is not difficult to understand, after all, where the Framers of the Malaysian Constitution were coming from. There is an abundance of empirical and historical evidence of the importance of just such group-membership criteria, or 'gateway principles' in respect of membership of the Malay race." Id. at 123. For a strong criticism of this argument, see Chandra Muzaffar, Universalism in Islam, in Liberal Islam 155 (Charles Kurzman ed., 1998).

352. Lim, supra note 351 , at $126-33$. 
ognized difference can be legitimately hard wired and ethno-religious federation serve as a legitimate basis for a constitutionalist settlement. ${ }^{353}$

As constituted, Malaysia incorporates Islamic elements within a structure that is also constitutionalist, in the sense of limiting and organizing power along principled grounds and subject to an ideology that protects against arbitrary or despotic assertions of power. ${ }^{354}$ But does it constitute theocratic constitutionalism in practice? Article 3 of the Malaysian Constitution declares Islam the official religion of the Federation. ${ }^{355}$ Islam has a privileged position within the polity. ${ }^{356}$ The state is required under Article 11(4) to protect Islam from competition from other faiths. ${ }^{357}$ That positive obligation is not solely based on the protection of religion per se, but in the case of Malaysia serves to protect what is viewed as an essential characteristic of Malay ethnicity-its religion. ${ }^{358}$ Still, the religious practices of other faith communities are protected, at least to the extent they are practiced in

353. See, e.g., Constitution of Malaysia (1957) art. 8 ("Except as expressly authorized by this Constitution, there shall be no discrimination against citizens on the ground only of religion, race, descent or place of birth in any law relating to the acquisition, holding or disposition of property or the establishing or carrying on of any trade, business, profession, vocation or employment.") [hereinafter Malaysia Constitution]. Commentators have noted that "[t]oday, the suggestion that the Constitution should be colour-blind would also (unfortunately) amount to sedition under Malaysian law insofar as that should question the Malay language provision in Article $152 \ldots$, or the special position of the Malays under Article 153, or the position of the Rulers under Article 181." Lim, supra note 351, at 128. But see Andrew Harding, The Keris, the Crescent and the Blind Goddess: The State, Islam and the Constitution in Malaysia, 6 Sing. J. InT'L \& Comp. L. 154, 164 (2002) ("Thus the most important function of constitutional law, apart from the function of making general provision for governance, is to ensure that the potentially fragile social fabric is kept intact. There is therefore already a tension between the principle of constitutionalism as such and a perceived need to maintain a religiously tolerant but politically authoritarian executive and a strong state.").

354. The federation is organized along parliamentary democratic lines, with separation of powers, strict procedures for lawful enactment of legislation, separation of powers, and the social rights principles of conventional constitutionalism. Also in line with conventional constitutionalist principles, the constitution serves as the supreme law of the land. See Malaysian Constitution art. 4; see also Mohammad Hashim Kamali, Islamic Law in Malaysia: Issues and Developments 28-58 (2000).

355. Malaysian Constitution art. 3(1) ("Islam is the religion of the Federation; but other religions may be practiced in peace and harmony in any part of the Federation.").

356. See, e.g., A hmad Ibrahim, The Position of Islam in the Constitution of Malaysia, in The Constitution of Malaysia: Its Development: 1957-1977, at 41 (Tun Mohamed Suffian et al. eds., 1978).

357. Malaysian Constitution art. 11(4) ("State law and in respect of the Federal Territories of Kuala Lumpur and Labuan, federal law may control or restrict the propagation of any religious doctrine or belief among persons professing the religion of Islam.").

358. Article $160(2)$ creates a legal definition of Malay ethnicity as grounded in language, religion, culture and place of birth. See id. art. 160(2) ("Malay means a person who professes the religion of Islam, habitually speaks the Malay language, conforms to Malay custom."). 
peace and harmony. ${ }^{359}$ Thus an element of toleration within a system of privilege (of Islam) and subordination (of all others) is made necessary by the construction of state organization on the basis of a dominant race religious construct-the $\mathrm{Ma}$ lay. ${ }^{360}$ Yet, Islam's privilege is constrained by the Constitution itself. ${ }^{361}$ And a system of conventionally described fundamental rights is specified. ${ }^{362}$ Moreover, the courts have resisted a constitutional interpretation that would use Article 3 as the engine through which Islamist constitutionalism could be imported. 363 "Thus primacy is given by the Constitution to religious rights even where the security of the state itself is at risk." ${ }^{364}$ Moreover, critical actors within Malay political culture have stressed the ambiguities of the Malay religious constitutional settlement. ${ }^{365}$

That ambiguity is emphasized by the nature of federalist devolution within Malaysia. ${ }^{366}$ The judicial power reflects this bifurcation. The Constitution creates a federal court system ${ }^{367}$ consisting of a set of High Courts ${ }^{368}$ with a Supreme

359. Id. art. 3 (declaring that, although Islam is the official religion of the Federation, "other religions may be practised in peace and harmony in any part of the Federation"); id. art. 11 (asserting that "[e]very person has the right to profess and practise his religion"); id. art. 153(1) (obligating government to preserve "the legitimate interests of other communities in accordance with the provisions of this Article."). In addition, Article 12 prohibits discrimination on religious grounds in the administration of public education and scholarships. Id. art. 12(1). This Article also permits religious instruction and the maintenance of an autonomous institutional life in any protected faith. Id. art. 12(2).

360 . Interestingly, at least one commentator has noted that even this expression of toleration might be un-Islamic. See Harding, supra note 353, at 158 n.9 ("A leading Muslim lawyer told the author that the word 'but' in Article 3 is insulting to Islam and should read 'and therefore.").

361. See Malaysian Constitution art. 3(4) ("Nothing in this A rticle derogates from any other provision of this Constitution.").

362. See id. arts. 5-13 ("Fundamental Rights").

363. Harding related that " $[\mathrm{t}]$ here is also no provision for the syariah to be a source, or the basic source, of legislation. The matter was in fact tested in the 1988 case of Che Omar v Public Prosecutor, in which it was argued that the enactment of a mandatory death penalty was contrary to Islam and therefore unconstitutional. The Supreme Court (now Federal Court) rejected this argument, holding that Article 3 was not a clog or fetter on the legislative power." Harding, supra note 353, at 166-67.

364. Id. at 168. Harding continues, "[t]his primacy has in effect been endorsed by the Supreme Court in Jamaluddin Othman, a habeas corpus case in which freedom of religion under Article 11 was held to override even the power of preventive detention under the Internal Security Act. The detainee, a Malay/Muslim who had converted to Christianity, was granted habeas corpus to secure his release from detention, which had been effected on the grounds that his alleged attempts to convert Muslims was a threat to national security." Id. at 168-69.

365. See, e.g., Anwar Ibrahim, The Asian Renaissance (1996). But see Hussin Mutalib, Islam in Malaysia: From Revivalism to Islamic State? (1993).

366. See Andrew J. Harding, Law, Government and the Constitution in Malaysia (1996).

367. Malaysian Constitution arts. 121-131 A.

368. Id. art. 121(1). 
Court at its head, ${ }^{369}$ along with syariah (shari'a) courts, which are creatures of state law. ${ }^{370}$ The jurisdiction of the federal courts is limited, and "shall have no jurisdiction in respect of any matter within the jurisdiction of the Syariah courts." ${ }^{371}$ But the Supreme Court's jurisdiction is broadly stated. ${ }^{372}$ The federal judicial establishment thus sits atop a governance system in which states have some authority to implement religious governmental systems and religious courts can serve to amplify this project. ${ }^{373}$ Malaysia thus offers a hybrid system, or per-

369. Id. art. 122.

370. See id. art 122(1A), sched. 9, list II.

371. Id. art. 121(1B).

372. The Supreme Court's jurisdiction extends to

(a) any question whether a law made by Parliament or by the Legislature of a State is invalid on the ground that it makes provision with respect to a matter to which Parliament or, as the case may be, the Legislature of the State has no power to make laws; and (b) disputes on any other question between States or between the Federation and any State.

Id. art. 128(1).

373. See Government of Malaysia, Constitution, http://www.gov.my/MyGov/BI/Directory/ Government/AboutMsianGov/GovConstitution (last visited Dec. 28, 2008) ("The Federal Constitution of Malaysia is the supreme law of the nation that distributes the power of governance in accordance with the practice of Parliamentary Democracy. The Constitution may be amended by a two-third majority in Parliament."). Article 74 of the Constitution divides power between the federal and state levels. The enumeration is contained in a Federal and a State List. Such a division of authority is subject to conditions and restrictions otherwise set forth in the federal constitution itself. See Malaysian Constitution, art. 74(3); see also id. art. 74(4) ("Where general as well as specific expressions are used in describing any of the matters enumerated in the Lists set out in the Ninth Schedule the generality of the former shall not be taken to be limited by the latter."). The Federal list exempts federal legislation of "Islamic personal law relating to marriage, divorce, guardianship, maintenance, adoption, legitimacy, family law, gifts or succession, testate and intestate," id. sched. 9, list I, $\S 4(\mathrm{e})($ ii), but it includes power to legislate over the machinery of government (subject to exempted powers devolved to the states) including the "[a]scertainment of Islamic law and other personal laws for purposes of federal law," id. art. 4(k), and "[g]overnment and administration of the Federal Territories of Kuala Lumpur and Labuan including Islamic law therein to the same extent as provided in item 1 in the State List." Id. art. 6(e). State legislative power includes a limited authority to impose Islamic law and legal structure. See id. sched. 9, list II (1). That provision permits state adoption of "Islamic law and personal and family law of persons professing the religion of Islam, including the Islamic law relating to succession, testate and intestate, betrothal, marriage, divorce, dower, maintenance, adoption, legitimacy guardianship, gifts, partitions and non-charitable trusts." Id. It also permits such regulation with respect to "Wakafs and the definition and regulation of charitable and religious endowments, institutions, trusts, charities and charitable institutions operating wholly within the State." Id. Most interestingly, it permits state Islamism with respect to the "creation and punishment of offences." But this power is limited to "persons professing the religion of Islam against precepts of that religion," and is further narrowed to cover only those offenses "in regard to matters included in the Federal List." Id. 
haps better put, a system in which two forms of constitutionalism are meant to coexist. Coexistence, however does not suggest convergence so much as compromise and separation within a system in which one of the two forms of approaches to constitutionalism-the conventional transnational variety-is privileged within the political system, but not entirely. ${ }^{374}$ The tensions that result seem to parallel the ethno-religious tensions of the multicultural, multi-ethnic and multireligious divisions within the state. ${ }^{375}$ The consequence will likely be continued dynamism as all groups compete for greater dominance over the evolution of the constitutional order until one or another constitutionalist system becomes clearly dominant or the nation fractures. ${ }^{376}$

\section{Sri Lanka}

While the focus has been on Islamic constitutions and the problems of theocratic constitutionalism within Muslim majority states, similar problems exist in non-Muslim states. One example is Sri Lanka, whose constitution on the one hand privileges Buddhism and on the other appears to adhere to the principles of transnational constitutionalism, provides a similar example of the difficulties.

Under the current Constitution of $1978,{ }^{377}$ Sri Lanka is established as a "free, Sovereign, Independent and Democratic Socialist Republic and shall be known as the Democratic Socialist Republic of Sri Lanka." 378 State policy is constitutionally binding on the government apparatus and includes the positive obligation to "establish in Sri Lanka a democratic socialist society, ${ }^{379}$ the objectives of which are set forth in the Constitution. None of the objectives refer to the state's religious character. Indeed, a careful reading of Article 27 suggests just the opposite--that

374. Thus, one commentator described Islamization in terms of domesticating and harnessing Islam for purely state power purposes during the Mahatir period. "The attempt to gain control of the flow of Islam in politics first led to an intricate policy of managing Islamist groups, and then to the Islamization initiative. The government devised a multipronged approach to containing and managing Islamism and curbing its extremism. It sought to co-opt moderate Islamist forces, marginalize and silence the extremists, and generally regulate all Islamic activity." Seyyed Vati Reza Nasr, Islamic Leviathan: Islam and the Making of State Power 113 (2001).

375. See Larry Catá Backer, Abdullah Badawi, Anwar Ibrahim and the Politics of Race, Ethnicity and Affirmative Action in Malaysia, Law at the End of the Day, http://lcbackerblog.blogspot .com/2008/03/abdullah-badawi-anwar-ibrahim-and.html (Mar. 9, 2008, 15:26 EST).

376. See Mutalib, supra note 365; Jomo K. Sundaram \& A hmad S. Cheek, The Politics of Malaysia's Islamic Resurgence, 10 THIRD WORLD Q. 843 (1988).

377. Constitution of the Democratic Socialist Republic of Sri Lanka, available at http://www.priu .gov.lk/Cons/1978Constitution/introduction.htm [hereinafter Sri Lanka Constitution].

378. Id. ch. 1 , art. 1.

379. Id. ch. 6 , art. $27(2)$. 
the state has been established as supremely secular and bound by the limits of post-1945 secular transnational constitutionalism based on the protection of fundamental rights and the assurance of human dignity and progressive economic policies. ${ }^{380}$ The appendage and contestable position of Article 9 in that context is magnified. Indeed, the "State shall ensure equality of opportunity to citizens, so that no citizen shall suffer any disability on the ground of race, religion, language, caste, sex, political opinion or occupation." 381

In the absence of a king, "sovereignty is in the people and is inalienable. Sovereignty includes the powers of government, fundamental rights and the franchise." ${ }^{382}$ Within this plausibly secular context, Buddhism is given a special place. The "Republic of Sri Lanka shall give to Buddhism the foremost place and accordingly it shall be the duty of the State to protect and foster the Buddha Sasana, while assuring to all religions the rights granted by Articles 10 and 14(1) (e)." ${ }^{" 383}$ Those assurances in Article 9 first protect freedom of conscience. "Every person is entitled to freedom of thought, conscience and religion, including the freedom to have or to adopt a religion or belief of his choice." ${ }^{384}$ In addition, every citizen is entitled to "the freedom, either by himself or in association with others, and either in public or in private, to manifest his religion or belief in worship, observance, practice or teaching." 385 Such rights can only be defeated on potentially narrow grounds, where the "interests of national security, public order and the protection of public health or morality, or for the purpose of securing due recognition and respect for the rights and freedoms of others" are at issue. ${ }^{386}$

No one is compelled to be a Buddhist. The Constitution merely requires one to live in a Buddhist state. And in the interests of such a state, but with due regard to the sensitivities of others, that state must protect and foster the Buddha Sasana, ${ }^{387}$ even where such fostering might otherwise impede the rights of others other than the right to believe and to manifest that religious belief in worship, observance, practice or teaching. In a Buddhist state in which the state itself must start from the assumption that the Buddhist view must prevail, the best protection afforded others is essentially the right to practice other religious beliefs unmolested. But

380. See id.

381. Id. ch. 6 , art. $27(6)$.

382. Id. ch. 1 , art. 3.

383. Id. ch. 2 , art. 9.

384. Id. ch. 3, art. 10.

385. Id. ch. 3 , art. 14(1) (e).

386. Id. ch. 3 , art. $15(7)$.

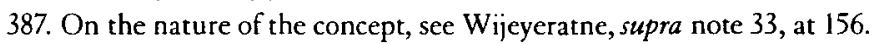


the price is that, though unmolested, they are cut off from the practices and understanding of the rest of society - for whose benefit the State must act under Article 9. However, the State also is obligated to "strengthen national unity by promoting co-operation and mutual confidence among all sections of the People of Sri Lanka, including the racial, religious, linguistic and other groups, and shall, take effective steps in the fields of teaching, education and information in order to eliminate discrimination and prejudice." ${ }^{388}$ Within these provisions, then, are elements of both substantive allocations of constitutional value to Buddhism and a positive obligation on the part of the state to foster those principles. That fostering is done through law, institutionalized in a constitution that also protects the individual rights of people even as it shapes the foundations of social organization around them in a way that might be inconsistent with their individual beliefs.

Sri Lanka thus presents an interesting wrinkle on the problem of classification within theocratic constitutionalism. The Constitution, as it has evolved, is at war with itself-is it the source of religious values constitutionalism, or does the reference to the religion of the majority serve merely to contextualize the transnational substantive values constitutionalism otherwise enshrined in the Sri Lankan constitution? The question revolves around the character of Article 9 in the context of other constitutional provisions. If Article 9 assumes a position of superiority in a hierarchy of constitutional values to be advanced, then Sri Lanka can move more confidently toward theocratic constitutionalization grounded in Buddhism. If it does not, then the 1978 Constitution is of a different order and the import of Article 9 becomes highly contestable, especially by the Tamil minority.

Evidence of intent might be found in the way the power of the judiciary to interpret the 1978 Constitution is framed. If the judiciary must interpret the 1978 Constitution in light of the principles of Buddhism, that would certainly push the characterization much closer to not only theocracy, but also closer to a constitutional theocracy of a kind similar to that imposed in Iraq and Afghanistan. The judicial power is set forth in Chapters 15 and 16 of the 1978 Constitution. ${ }^{389}$

This leads to a curious result. First, the broad principles of state policy in which the state is founded articulated in Article 27 are not justiciable. "The provisions of this Chapter do not confer or impose legal rights or obligations, and are not enforceable in any court or tribunal. No question of inconsistency with such provisions shall be raised in any court or tribunal." ${ }^{390}$ The Supreme Court "shall

388. Sri Lanka Constitution ch. 6, art. 27(5).

389. Id. chs. $15,16$.

390. Id. ch. 6 , art. 29. 
have sole and exclusive jurisdiction to hear and determine any question relating to the interpretation of the Constitution" 391 It is granted broad constitutional review powers other than with respect to matters related to popular revisions of the constitution itself. ${ }^{392}$ But the Constitution itself does not bind the court to a particular form of constitutional interpretation. On the one hand that might suggest that the 1978 Constitution is not theocratic. But we must still deal with Article 9. It would be possible, consistent with the other provisions of the Constitution, to create a hierarchy of constitutional values in which Article 9 serves as the supreme principle of constitutional jurisprudence - the animating force of substantive values inherent in the Constitution. That certainly would be consistent with the socio-cultural religious views of the majority Sinhalese as so well described by Roshan de Silva Wijeyeratne. ${ }^{393}$ It would, as well, comport with the form of a reading of constitutional norms as suggesting a hierarchy of norms developed well by the German Constitutional Court since the 1950s. ${ }^{394}$

Thus reconstructed, Article 9 could serve as the foundation through which all fundamental rights are read and all protections to non-Buddhist others are understood. This would be consistent with the construction of a theocratic constitutionalist state, producing applications that might be substantially different from those that might be produced through an interpretative framework grounded in secular transnational norms identified through customary and conventional international law.

But there is no clear answer. There has been a temptation to theocratic constitutionalism to which the Sri Lankan legislature has come close to succumbing. In 2005, for example, "Sri Lanka's parliament [discussed] the 'Bill on the Prohibition of Forcible Conversions,' which had been proposed in 2007 by the Buddhist Jathika Hela Urumaya (JHU) party. ${ }^{\text {"395 }}$ But both government and Supreme Court did little to further the effort. ${ }^{396}$ Sri Lanka has put itself in a position of what may be termed soft theocratic constitutionalism. Theocracy remains a potent but contested potential substantive basis for the generation of constitutional values. Until there is a bit

391. Id. ch. 16 , art. 125 .

392. Id. ch. 16, arts. 120-23, 126-31.

393. See de Silva Wijeyeratne, supra note 33.

394. See Larry Catá Backer, Cosmopolitan Ideals, the European Union and its Judiciary, Law at the End of the Day, http://lcbackerblog.blogspot.com/2006/09/cosmopolitan-ideals-europeanunion-and.html (Sept. 22, 2006, 22:59 EST).

395. Marta Allevato, Sri Lanka's Anti-Conversion Bill a "Worry" Even for Benedict XVI, Ası News, May 5, 2005, http://www.asianews.it/view.php:l=en\&art=3219.

396. See U.S. Dep't of State, International Religious Freedom Report 2005 (2005), available at hetp://www.state.gov/g/drl/rls/irf/2005/51622.htm. 
more clarity, Sri Lanka will continue to reap the worst of both worlds-as a failed theocratic and a failed secular transnational constitution. It neither applies the substantive values of its Buddhist norm framework, nor does it adhere completely to the global secular system of human rights and rule of law norms.

\section{CONCLUSION}

Constitutionalism remains a messy business. In a sense, we live in a time of constitutionalist anarchy. This anarchy might well mirror the anarchy in international relations as any number of states-and the values they represent-vie for authority and a place within the hierarchy of nations. The object of this article has been to suggest that the project of building constitutionalism-a particular worldview and ideology for distinguishing between legitimate and illegitimate expressions of popular will in the form of domestic constitutions- has given rise to transnational as well as nationalist versions of this project. Both seek to legitimate by positing "good" constitutional arrangements as those that prohibit arbitrary expressions of power and which limit that power in accordance with a system of norms that reflect the "good" or right and justice. ${ }^{397}$ The "good" or right and justice, can itself, if left solely to the will of majorities, produce tyranny. Thus, a great object of constitutionalism has been the embrace of normative systems against which the actions of a sovereign will can be measured and limited. Transnational constitutionalism suggests that the articulation of those substantive limits on expressions of domestic power and governance are best when they are removed from the discretion of any single polity and situated within the community of nationsno one state can control it, but all states can contribute to its expression, and every state can incorporate its directives in a context-specific way. In its nationalist version, substantive norms can be found within articulated communal values or universal principles of right and justice found within natural law or in notions of civilized behavior or by reference to universal nonpolitical principles-for example the economic determinism of the failed Marxist universalist project.

It also suggests that there is no consensus on any set of global bases for determining a norm structure limiting domestic constitution making and binding all states. However incompatible it might seem to dominant values in other parts of the world and among other significant segments of the global community, there has risen a new expression of principled constitutionalism-constructed on the founda-

397. See Larry Catá Backer, The Mechanics of Perfection: Philosophy, Theology and the Perfection of American Law, in On Philosophy in American Law (Francis J. Mootz, Jr. ed., 2009). 
tion of institutionalized religion. This principled constitutionalism inverts the conventional form of constitutionalist organization, which privileges the values and norms of the community of nations (contextualized within a polity), by privileging the universal and eternal values derived from religion as a basis for interpreting and elaborating systems of governance and law. Yet, at the same time, it provides a basis for constructing states that avoid both arbitrary expressions of power and the use of power unlawfully, constraining its deployment and expression by means of principles and institutional frameworks beyond the power of individuals to subvert. What makes these systems so threatening to those constructing secular transnational or nationalist constitutionalism are their similarities to the forms of legitimating constitutionalism (and thus its potential authenticity) and their potential for reaching conclusions about the nature of the good and the right and just incompatibly different from that nurtured under other systems. Theocratic constitutionalism includes and excludes privileges and subordinates individuals in ways that can be very different from the ordering of power hierarchies in the West. It rests on inclusiveness and a notion of difference significantly different from that developed among the community of nations after 1945 and expressed in a variety of international law instruments. It would undo or redo the emerging system of supranational human rights institutions in its own image. But within its own contextual universe, it can provide as sound a basis for ordered and rule of law government as that offered by transnational constitutionalism.

There is now a market for constitutionalism. Each of these constitutionalisms are authentic and serve to legitimate the organization of states within frameworks that promote rule of law and the institutionalization of process and values. Each posits a distinction between a principled and an unprincipled organization of government, its operation, functioning, organization, objectives, limits, and relationship with critical stakeholders. ${ }^{398}$ Within that market at least three major products are offered, each with a large number of variations. These three--nationalist constitutionalism, transnational constitutionalism and theocratic constitutionalism-have produced a rich literature. Each claims to be the only legitimate basis for conceptualizing the legitimate constitution of states. Each imposes a hierarchy of values in which the universal provides a framework within which some variation is possible,

398. The legitimization aspect provides a powerful impetus to adhere to the form of constitutionalism and gives rise to the need to police against imposters-either as sham democracies under secular constitutionalism or as constitutional theocracies under theocratic constitutionalism. For a discussion on sham constitutional theocracy and a move towards theocracy in Pakistan as a legitimating move, see Siddique \& Hayat, supra note 290 , at 316-22. 
but only to the extent that it is compatible with a consensus reading of the framework norms. Each reflects a series of values and assumptions that make accommodation with other worldviews difficult at a fundamental level. ${ }^{399}$ For all that, compatibility, as applied, might be possible. ${ }^{400}$ That compatibility might well be necessary in a world in which the sources of constitutionalist legitimacy will remain highly contested. But it also suggests that in the absence of equilibrium through the singular domination of a particular constitutionalist worldview, legitimating constitutionalism-as doctrine and political project-will remain in a highly dynamic state. For those championing one or another version and seeking to convince the polities of particular states to join one or another camp, it behooves the players to better understand competing systems to meet them on their own terms, and to better structure arguments suggesting principled reasons for abandoning one in favor of another. Alternatively, as is increasingly evident today, each group will seek, by appearing to seek convergence, to move the other system closer to its own. In any case, religion will be in the thick of it, from all sides of engagement. ${ }^{401}$

399. This is the way Eric Heinze, for example, largely understood the reaction of the Chairman of the Nigerian Islamic Human Rights Council to the Nigerian fornication case. See Eric Heinze, Even Handedness and the Politics of Human Rights, 21 HaRv. HuM. RTs. J. 7 (2008). Reacting to the view that

Shadjareh claimed that "Hudood punishments under the banner of shariah in a secular state are unacceptable and cannot be the starting point for the implementation of shariah." He narrowed that view, however, in stating, "[a] woman who is not married at the time of accusation of fornication does not deserve capital punishment." The IHRC further states the view of the "majority" of schools of thought, according to which the appropriate punishment would have been "a certain number of lashings."

Id. at 23. Heinze stated, "[ $t]$ hat view, which the IHRC at no point challenges, cannot be called a compromise position or a reconciliation of Islam with international human rights law. It is a categorical rejection of core human rights; namely, against cruel, inhuman, or degrading treatment (if not torture), as well as, arguably, privacy or freedom of conscience or religion." Id.

400. For an argument to that effect, see Fadel, supra note 167.

401. For an interesting expression of that drive, from the mouth of the Archbishop of Canterbury, and in the context of domestic constitutionalism, see Larry Catá Backer, The Church of England Speaks to the Relationship Between Law and Religion, Law at the End of the Day, http://lcbac kerblog.blogspot.com/2008/02/church-of-england-speaks-to.html (Feb. 4, 2008, 17:44 EST). 